\title{
MATÉRIA SECA, ABSORÇÃO E EXPORTAÇÃO PELOS GRÃOS, DE N, P, K, CA, MG, S, B, CU, FE, MN, E ZN PELO TRIGO, SOB REGIME DE SEQUEIRO E IRRIGADO EM LATOSSOLO ROXO
}

JOSÉ UBIRAJARA GARCIA FONTOURA

Orientador: Dr. HENRIQUE PAULO HAAG

Tese apresentada à Escola Superior de Agricultura "Luiz de Queiroz", da Universidade de São Paulo, para obtenção do título de Doutor em Agronomia. Área de Concentração: Solos e Nutrição de Plantas.

PIRACICAB A

Estado de São Paulo - Brasil

Dezembro - 1986 
ii.

I minha esposa RUTH

Aos meus filhos LEONARDO

CRISTIANO

Aos meus pais RAUL

IURACENA

AOs meUs IRMAOS, 
i i i .

\section{AGRADECIMENTOS}

Ao Professor Henrique Paulo Hag, pela orientação, apoio e amizade;

Ao colega Amoacy Carvalho Fabricio pelo zpoio e companheiris -mo prestados na realização deste trabalho;

Ao Professor Décio Barbin do Departamento de Estatística e Matemática pela orientação na realização das anālises es tatísticas;

A Empresa Brasileira de Pesquisa Agropecuāria - EMBRAPA, pe la liberação e apoio para. realização do curso de Pös-Gra duação;

Ao Conselho Nacional de Desenvolvimento Cientifico e Tecinolögico - CNPq, pela ajuda financeira;

Ao Departamento de Química da ESALQ, nas pessoas dos Profes sores Antônio R. Dechen e Quirino A. de C. Carmello e aos Técnicos de Laboratório Lucia H.S. Pavan, Lurdes A.D. de Gonzâlez e Claudemir formaggio, pelas facilidades e ajudas oferecidas nas análises dos nutrientes;

Ao Centro de Informātica na Agricultura - CIAGRl da ESALQ, nas pessoas do Estatistico Gabriel Adrian Sarries e os estagiários Carlos Eduardo F. dos Santos, Evandro Hayashi e l.igia H. Valdrighi, pela realização e ajuda nas arāa i ises estatísticas;

Aos Professores do Curso de Solos e Nutrição de Plantas, felos ensinamentos ministrados; 
Aos colegas Josë Carlos Fachinello, Morel Pereira Barbosa Fi Iho e Luiz Carlos Hernani pela amizade, companheirismo e colaboração durante o curso, e

Aos demais colegas e funcionärios da UEPAE de Dourados, MG da EMBRAPA, que de algum modo tenham contribuído para a rea lização deste trabalho. 


\section{THDICE}

Pägina

RESUMO $\ldots \ldots \ldots \ldots \ldots \ldots \ldots \ldots \ldots \ldots \ldots \ldots \ldots \ldots \ldots \ldots \ldots \ldots$

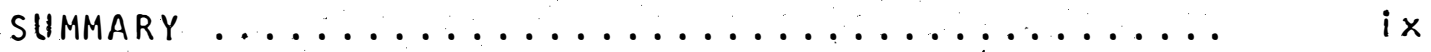

1. INTRODUÇAOO......................... 01

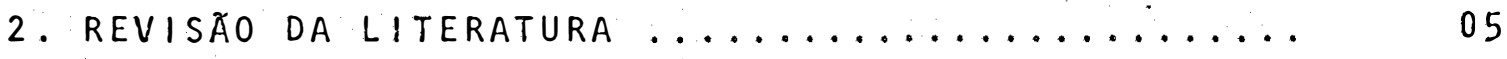

3. MATERIAL E METODOS .................. 18

3.1. Local de execução do ensaio............ 18

3.2. Instal ação do ensaio ................ 20

3.3. Condução do ensaio e determinação dos nutri

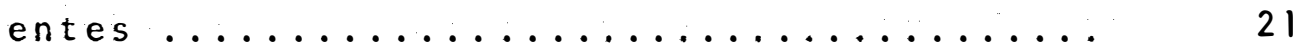

3.4. Anälise estatística ...................... 25

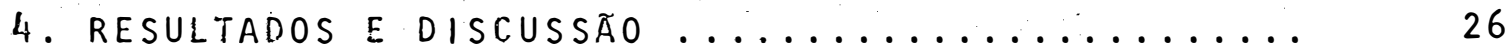

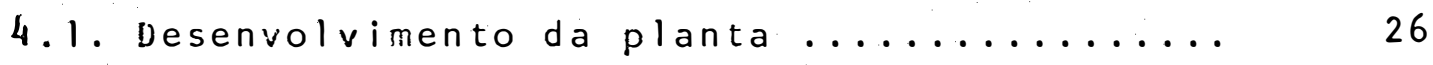

4.2. Concentração e acümulo de nutrientes naś

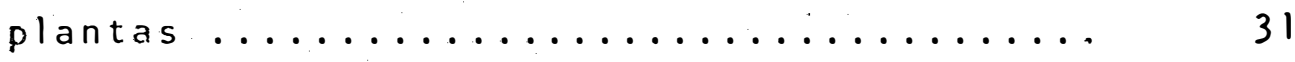

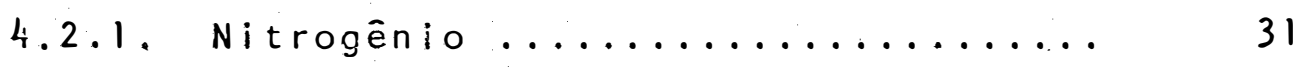

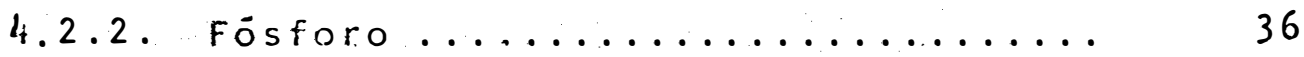

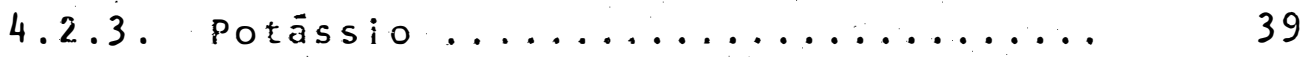

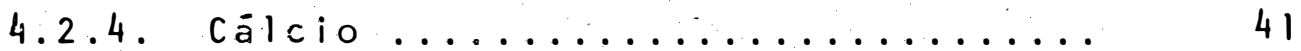

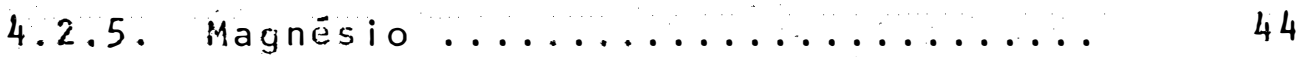

4.2 .6$. Enxofre ................ 47

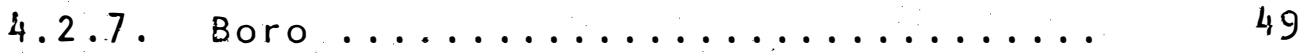

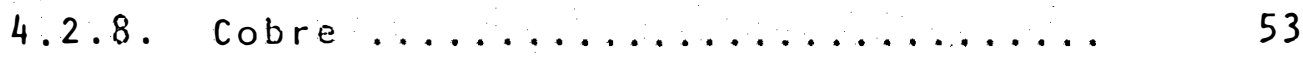

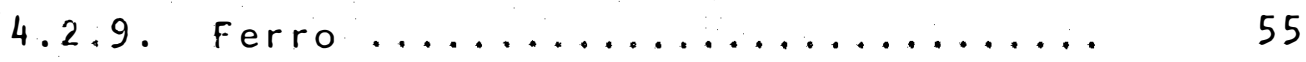

4.2 .10 . Manganès ................. 57

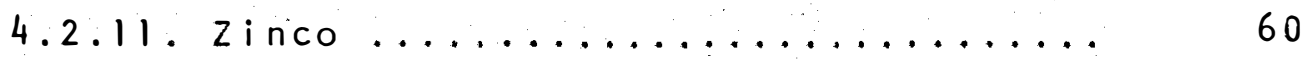


vi .

Pàg ina

4.3. Acúmulo de matéria seca enutrientes nas par

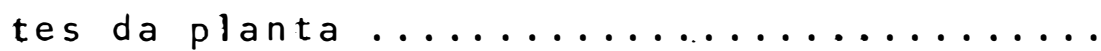

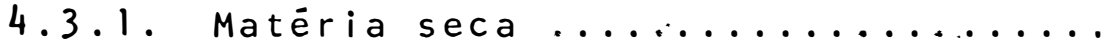

$4.3 .2 . \quad$ Nitrogênio $\ldots \ldots \ldots \ldots \ldots \ldots \ldots$

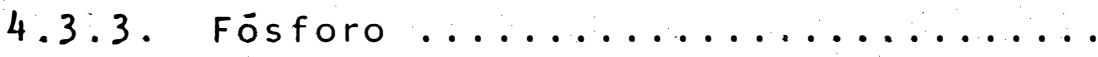

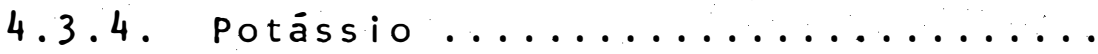

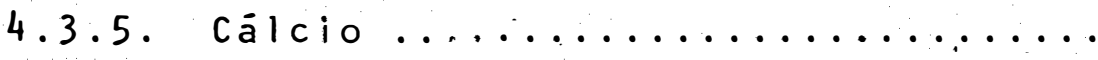

74

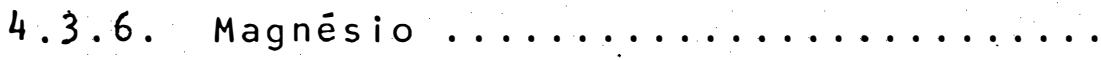

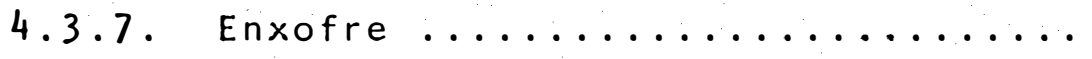

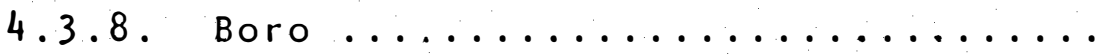

$4 \cdot 3 \cdot 9$

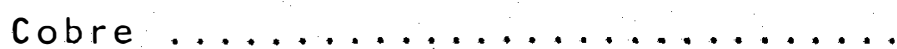

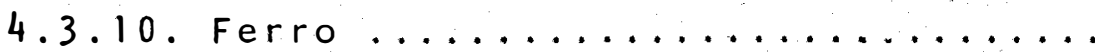

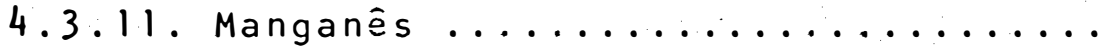

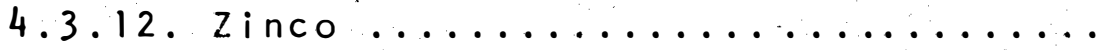

4.3.13. Distribuição percentual de matéría seca e nutrientes nos órgãos da plan

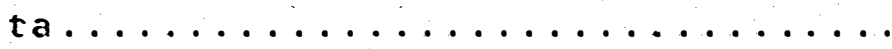

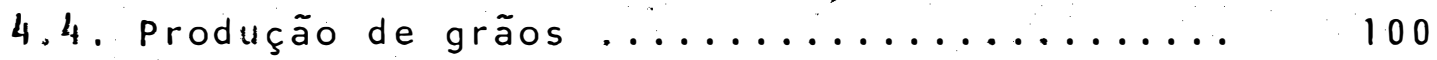

4.5. Consumo e exportação de nutrientes ....... 103

4.6. Eficiência na utilização de nutrientes.... 106

4.7. Considerações gerais ................... 108

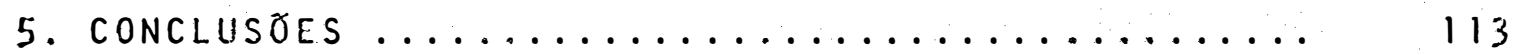

6. LITERATURA CITADA ................... 116 
vii.

MATERIA SECA, ABSORÇÃO E EXPORTAÇÃO PELOS GRÃOS, $D E N, P, K, C a, M i, S, B, C u, F e, M n$ e $Z n$ PELO TRIGO, SOB REGIME DE SEQUEIRO E IRRIGADO EM LATOSSOLO ROXO

Autor: JOSE UBIRAJARA GARCIA. FOUTORA

Orientador: Dr. HENRIQUE PAULO HAAG

\section{RESUIO}

o presente trabalho foi realizado com o objeti vo de determinar a produção de matéria seca e absorção cumula Eiva de N, P, K, Ca, Mg, S, B, Cu, Fe, Mn e Zn na pianta, pro dução de grãos e exportação de nutrientes pelas cultivares de trigo BH 1146, de porte alto e com tolerância a deficiência hídrica e IAC 24-Tucuruí, de porte baixo e com média tolerância a deficiência hídrica, sendo ambas de ciclo médio, em duas disponibilidades de água, sequeiro e irrigado. 0 experimento de campo foi realizado na Unidade de Execução de pesquisa de Ambito Estadual da Empresa Brasileira de Pesquisa Agropecuária - EMBRAPA em Dourados, MS, em Latossolo Roxo distróficoargiloso, àdubado com $20 \mathrm{~kg}$ de $\mathrm{N}$ e $90 \mathrm{~kg}$ de $\mathrm{P}_{2} \mathrm{O}_{5}$ por hectare. Para determinação da acumulação e teor dos nutrientes na parte aérea das plantas, foram feitas coltieitas aos 10 dias de idade, início do perfilhamento; aos 30 dias, elongamento do colmo; aos 50 dias, emborrachamento; aos tu dias, floração; 
vii i.

aos 90 dias, grão leitoso; e aos 110 dias, maturação. Aos 90 e 110 dias, as plantas foram divididas em suas partes para de terminar o acümulo dos nutrientes nos colmos, folhas, folhas bandeira, grãos e espigas. Em parcela adicional na maturação foi determinado o rendimento de grãos por ärea, peso de mil sementes e peso do hectolitro. Os resultados mostraram que a irrigação determinou maior acümulo de matéria seca por plan ta e matēria seca por ärea, nas duas cultivares e em todas as idades. Os teores de macronutrientes decresceram até a maturação e os de micronutrientes até o estädio de grão leitoso. Em regime de sequeiro a cultivar IAC 24-Tucuruímostrou maior acūmulo de matēria seca, N, Ca, B, Cu e Fe, e com irrigação acumulou mais matéria seca, N, K, Ca, Mg, S, Cu, Mn e Zn, em relação a BH 1146. A produção de grãos por hectare foi maior em irrigação e a exportação percentual de nutrientes foi na se guinte ordem: $\mathrm{P}>\mathrm{N}>\mathrm{Mg}>\mathrm{S}>\mathrm{K}>\mathrm{Ca}>\mathrm{Zn}>\mathrm{Cu}>\mathrm{B}>\mathrm{Mn}>\mathrm{Fe}$. Em sequeiro as duas cultivares mostraram maior eficiência na utilizaçäo de todos os nutrientes. 
DRY MATTER PRODUCTION, CUMULATIVE UPTAKE AND EXPORTATION OF MINERAL NUTRIENTS BY TWO WHEAT CULTIVATES, BH 1146 AND IAC 24-TUCURUT UNDER TWO CONDITIONS OF LEVELS OF WATER IN A LATOSSOLO ROXO SOIL, IN THE STATE OF MATO GROSSO DO SUL, BRAZIL.

\author{
Au"hor: JOSE UBIRAJARA GARCIA FONTOURA \\ Adviser: Dr. HENRIQUE PAULO HAAG
}

\title{
SUPMMARY
}

An experimental trial was carried out to determine the dry matter production, the accumulation of $N, P$, $\mathrm{K}, \mathrm{Ca}, \mathrm{Mg}, \mathrm{S}, \mathrm{Cu}, \mathrm{B}, \mathrm{Fe}, \mathrm{Mn}$ and $\mathrm{Zn}$ in the aerial parts of wheat plants with the main purpose of analyze some rutrition aspects of wheat plants submitted to two level of water avalability. The cultivates used were: $B H 1145$ recomended for non irrigated areas and IAC 24-Tucuruí recomended for medium fiooded areas. The experimental trial was carried out in the EstgRAPA experimental station at Dourados, MS on a Latosol Roxo soil (Eutrustox). The experimental area was fertilized with $20 \mathrm{~kg}$ of $\mathrm{N}$ and $90 \mathrm{~kg}$ of $\mathrm{P}_{2} \mathrm{O}_{5}$ per hectare. The plants were cuted and analyzed at the following stages: 10 days, at the beginging of tillering; 30 days, at the stem alongation; 50 days at the jointing; 70 days, at the flowering; 90 days, at the beging of grain formation and 110 days at the maturity of the grains. With go 
and 110 days of age the plants were divided into stems, leaves, flag leave, grains and heads. An aditional area were determinedd wheight of 1,000 seeds and hectilitre and grain yield.

Conclusions:

1) The irrigation increased the dry matter production in both cultivares in all ages;

2). The concentration of the macronutrients decreased with with the increase of the age of the plants until the maturity and the concentration of the micronutrients decreased until the beging of grain formation;

3) Under dryland the cultivate IAC 24 -Tucurui showed the highest dry matter production and accumulation of $N, \mathrm{Ca}, \mathrm{B}, \mathrm{Cu}$ and $\mathrm{Fe}$. With irrigation the cultivate IAC $24-$ Tucurui showed the highest dry matter production and accumulation of $\mathrm{N}, \mathrm{K}, \mathrm{Ca}, \mathrm{Mg}, \mathrm{S}, \mathrm{Cu}, \mathrm{Mn}$ and $\mathrm{Zn}$ than the cultivate $3 \mathrm{H} 1146$;

42 The grain yield was highest with irrigation and the nutrients were exported in percentual value in the following order: $\mathrm{P}>\mathrm{N}>\mathrm{Mg}>\mathrm{S}>\mathrm{K}>\mathrm{Ca}>\mathrm{Zn}>\mathrm{Cu}>\mathrm{B}>\mathrm{Mn}>$ $>\mathrm{Fe}$; and;

5) Under dryland cultivation: the two cultivates was more effective utilization of the nutrients. 


\section{INTRODUSAO}

\section{o trigo (Triticum aestivum L.) é um cereal de}

grande importância na alimentação humana, na maioria dos países do mundo. Tanto sua àrea de cultivo como produção total, situam-se em primeiro lugar entre os cereais. A ärea total e produção mundial em 1983 foram respectivamente 231,9 mi inões de hectare e 521,7 milhões de toneladas, resultando numa procutividade média de $2.250 \mathrm{~kg} / \mathrm{ha}$ (FAO, 1984).

No Brasil a ārea mëdiá cultivada, no periodo de 1973-78, era de aproximadamente 2,7 milhões de hectares e uma produção de 2,0 milhões de toneladas, o que representava $1,18 \%$ do total mundial e uma produção. de $0,63 \%$ (TOMAsıN।, 1982). No período de 1980-85 a média de área cultivada anual esteve abaixo de $2,5 \mathrm{milhões} \mathrm{de} \mathrm{hectares} \mathrm{e} \mathrm{produção} \mathrm{mëdia} \mathrm{de}$ aproximadamente 2,55 milhöes de toneladas, proporcionando assim uma produtividade média anval je $1000 \mathrm{~kg} / \mathrm{ha}$ (EMBRAPA, 1983 - BANCO dO ZRASIL, 1986). Heste Ü!tino periodo, os Estados 
brasileiros que mais contribuíram para a produção foram, Paranā, Rio Grande do Sul, São Paulo e Mato Grosso do Sul com 53,$20 ; 32,44 ; 6,23$ e $5,85 \%$ respectivamente, do total daprodução.

A cultura do trigo localiza-se principalmente nas äreas de clima temperado, ou seja, no sul do país. EntreLtanto, nos ūltimos dez anos tem-se expandido para as áreas de clima sub-tropical e tropical das regiões Centro-sul e cen tro-Oeste (BRASIL, 1985).

A àrea cuittivada, produção e produtividade tem apresentado variações nos ültimos dez anos devido a uma falta de estabilidade nas politicas de financiamentos da cliltura, preço mínimo da produção e fracassos de safra (TOMASINI, 1982). os fracassos de safra são devidos às variações climáticas no decorrer do ciclo oa cultura, principalmente, deficiências ti dricas, excesso de chuvas e temperaturas baixas em períodoscri ticos da cultura. Estas adversidades ciimáticas, além de cau sarem problemas ao desenvolvimento da planta, favorecem o aparecimento de enfermidades ria cuitura (MOTA, 1982).

Nas regiões localizadas acima da latitude de $24^{\circ} \mathrm{S}$, especialmente no norte e oeste to Estado do Paranā, São Paulo e sul do Mato Grosso do sul o cultivo é feito no período outcno-inverno, onde as, precipitações pluviais são escassas e as temperaturas médias são elevadas (sILVA, 1971). Nestas äreas, os plantios são feitos atravös do sistema de segueiro, aproveitando somente as aguas das chuvas, forem ros 
ültimos anos, alguns pesquisadores vem estudando a irrigação suplementar para esta cultura (SILVA, 1976; SILVA et alii, 1982 e CALHEIROS et alii, 1986).

Existe um elevado nümero de cultivares estuda- das e adaptadas para as condições de clima temperado (OSORlo, 1982). Ao passo que para as condições de clima troplcal e sub-tropical, principalmente para plantios irrigados, o número de cultivares é restrito e seu comportamento e exigências nutricionais nestas condições säo pouco estudacios.

Em regiões onde há deficiência hídrica no período de cultivo do trigo, as pesquisas con uso de irrigação mostram que é possivel duplicar ou triplicar a produção das cultivares normalmente cultivadas sem irrigação (BASSIRI E NAHAPETIAN, 1977).

A nutrição adequada da planta é fundamental pa ra a obtençãc de altas produtividades. E, partindo-se da hipótese de que a produção de matéria seca e ắsorf̧ão de nutrientes pela planta e seus órgãos pode variar en cada cultivar e adaptabilidade a diferentes disponibilidades de água, enten deu-se que o maior conhecimento sobre estas características fa cilitaria a recomendação de cultivares, dosês e épocas de apli cação de nutrientes (GASSER \& THORBURN, 1972. SHIMSHI \& KAFKAF1, 1978 E KARLEN \& WHITNEY, 1980).

Esta pesquisa visa estudar a produção de natëria seca e absorfão cumulativa de nitrogênion, fósforo, potássio, cälcio, magnésio, enxofre, boro, cobre, ferro, manganês 
e zinco na planta, produção de grãos e exportação de nutrientes pelas cultivares de trigo BH 1146 e IAC 24-Tucurui em regime de sequeiro e irrigado. 


\title{
2. REVISÃO DE LITERATURA
}

\begin{abstract}
Na revisão foi possivel constatar, que os cstu dos com absorção de nutrientes peìa planta de trigo, foram intensificados nas ültimas três dēcadas. Até entäo, o nutriente mais estudado era o nitrogênio, considerando-se apenas as condições naturais de clima e sem diversificação de cultiva res. Nos ültimos trinta anos foram intensificados os estudos com outros nutrientes, principalmente fósforo, potässio, càlcio e magnésio. A partir daí vem sendo consideradas as diferentes condições ambientais, cultivares e disponibilidades de âģua.
\end{abstract}

No Brasil, atê recentemente os estudos com a cultura concentravam-se principalmente no sul do pais, princi palmente visando o melhoramento genético da espécie para melhor adaptą̧ão às adversidades de clima e solo e resistêncía às enfermidades. Os estudos com nutrição e adubação da cuitura visavam principalmente o fornecimento de nutrientes para a ob 
tenção de altas produtividades, não havendo preocupação quanto as necessidades nutricionais da planta (EMBRAPA, 1984).

Os levantamentos bibliogräficos sobre trabalhos realizados com a cultura no Brasil. (EMBRAPA, 1981 e EMBRAPA, -1984) mostram que de aproximadamente 1500 trabalhos cataloga dos, menos de dez referem-se a concentração e acümulo de nutrientes pela planta.

Esta revisão visou pesquisar a existência de trabalhos semelhantes ou correlatos que permitisse maior suporte científico a esta pesquisa. E, na medida do possível, as citações serão colocadas ordenadamente com estudos de produção de matēria seca, concentração e acúmulo de nutrientes, produção de grãos por ārea e exportação de nutrientes por di ferentes cultivares sob a influência de diferentes disponibilidades de ägua.

Estudando a produção de matéria seca eni trigo em condições de campo BOATWRIGHT \& HASS (1961) relatam que a planta atinga o mäximo de produção no estä́dio de emissão da espiga e que a partir do início da formação do grão hä uma acentuada queda no teor de matéria seca nas diversas partes da planta e um crescente aumento no gãa até o final da maturação.

A produção a acúmulo de matéria seca na parte vegetativa e nos grãos, alén de outros fatores, depende das caracteristicas genēticas das cultivares e da disponibilidade de água durante o seu desenvolvimento. Mclleft et alii (1965) tra 
balhando com cinco cultivares americanas de trigo nos EUA mos traram que o máximo desenvolvimento das folhas ocorreu na flo ração e do colmo no estádio da ântese. No entanto as cultivares não mostraram diferenças quanto ao seu crescimento firnal.

GAMA (1977a e 1977b) estudando a nutrição da pianta de trigo em vasos com solo de textura franco - arenosa em Portugal, obieve uma produção máxima de matéria seca de $8,14 \mathrm{~g} / \mathrm{planta}$ e um acúmulo máximo de magnésio, cálcio, potásF sio e enxofre de $22,29,113$ e 37 mg/pianta, respectivamente. Para estudar os estádios de desenvolvimento da planta de trigo, acúmuio de matéria secá, nitrogênio, fósfor e potássio, WALDREN \& FROWERDAY (1979), conduziram experimentos em condições de campo, nos EUA durante três anos conse cutivos. Concluíram que o máximo de matéria seca da folha ocorria no estádio da fioração e do colmo até o início da formação do grão. Em relação ao conteúdo total na planta, atē a maturação houve um acúmulo no grão de $38 \%$ da matéria se ca, $71 \%$ do nitrogênio, $75 \%$ do fósforo e $17 \%$ do potássio. Sendo que o máximo acümulo verificado por planta foi de $7,61 \mathrm{~g}$ de matēria seca, $94 \mathrm{mg}$ de nitrogênio, 16 . $\mathrm{mg}$ de fösforo e $146 \mathrm{mg}$ de potássio.

O acūmulo de matéria seca na planta inteira se gundo KARLEN \& WHITNEY (1980), obtido em experimentos em Kansas, USA, obedece o modelo de curva sigmóide, desde a germinação até a maturação, ocorrendo um acúmulo mínimo até o ini- 
cio da elongação do colmo, atingindo o máximo na maturação fi siológica e diminuindo na maturação final. O mesmo estudo, mostra o comportamento do acúmulo de nutrientes nas diferentes partes da planta, desde o início da fase vegetativa até a maturação final, onde foram constados diferentes teores de nutriẹtes em cadí órgão. A concentração de nitrogênio, fósforo, enxofre e cobre nas folhas decresceu linearmente at a planta-atingir a maturação, sendo que a de potássio foi relativamente constante até o início da floração, decrescendo a partir daí, no entanto, o teor de magnésio manteve-se mais ou menos constante durante todo o cicloe e de manganés e zin co mostraram variações ao longo do ciclo. No colmo a concentração de nitrogênio e enxofre decresceu désde a elongação. áte a maturação risiológica; o fósforo, potássio, cálcio, mag nésio e zinco decresceu desde a elongação até a floração, ten dendo a uma constância próximo a maturação fisiológica. Nás espigas, a concentração de nitrogênio, fösforo, magnésio, enxofre e manganès foi muito variăvel durante o desenvolvimento das mesmas, sendo que o potássio decresceu a partir da emissão. Nos grãos a concentração de nitrogênio, fúsforo, potässioo, câlcio e magnésio näo apresentou variações do inicio ào final do seu desenvolvimento, sendo os teores de manganés e zinco mito variāveis.

Conduzindo diversos experimentos na Austrälia, en vasos, com objetivo de estudar a influência da irrlgaçäo sobre o trigo, Alston(1980) concluiu que com irrigaräo conti- 
nua a produção de matēria seca da palha e dos gräos foi maior do que com o tratamento que recebeu somente uma irrigação. No entanto, a concentração de nitrogênio e fósforo foi superior quando a planta recebeu uma irrigação no início do ciclo.

Atravēs de pesquisa, em ambiente controladocom a utilização de fósforo radioativo, realizada no Canadá, RENNIE (1956), concluiu que o tipo de solo e clima influenciaram mais fortemente no teor de fósforo acumulado no grão do trigo do que a fonte de fertilizante fosfatado utilizado.

o conhecimento sobre o desenvolvimento da plan ta, a quantidade de nutrientes absorvidos e exportados pelos grãos é importante para fazer-se as futuras recomendações de adubação. A este respeito, PETERSON (1965) relata que os mi cronutrientes se encontram em maior quantidade na matēria seca dos grãos do que da palha. Sendo que, KALCKMANN E PILCZER (1966) trabalhando em solos brasileiros observaram que os maiores teores de nitrogênio e fósforo estão localizados nos grãos, enquanto o potássio se acumula em major guantidade na parte vegetativa da planta.

GASSER \& THORBURiN (1972), corduzindo experime $\underline{n}$ tos com e sem irrigação em condiçōes yaturais na Inglaterra, concluiram que o suprimento de água influi đáferentemente em cada nutriente. Com o uso da irrigação aumentaram os teores de fósforo, potàssio e sódio na palha e diminuiram os teores de nitrogênio, cälcio e magnésio, no entanto nas espigas decresceram os teores de potássio, cáicic e megnésio e cresceram os de nitrogènio, fösforo e magnésio. 
Em concordância ao trabalho anterior, BASSIRI E NAHAPETIAN (1977) relatam que através de pesquisa realizada no Iran, com oito cultivares de trigo iranianas e duas mexicanas sob condições de irrigação. e sequeiro a concentra - ção média de fösforo foi maior no tratamento irrigado e a de cálcio e magnésio foi menor. No entanto, a concentração média de zinco e ferro não diferiu nas duas disponibilidades de ägua, as sim como não houve interação entre cultivares e irrigação.

Estudando a absorção de nutrientes com as cul tivaress trasileiras BH 1146 e IAS 3795, em casa de vegetãẵo, usando Latossolo Vermelho-escuro, fase arenosa, GARGANTINI E BLANCO (1973), observaram que nos primeiros 21 dias de idade o trigo tem crescimento lento e a partir dai cresce mais intensamente, cessando o crescimento em altura no estädio do fiorescimento. Foi verificado que a cultivar IAS 3795 produziu maior quantidade de matēria seca total. Com relação aos nutrientes a cultivar BH 1146 atingiu maior concentraçäo de todos os macronutrientes na parte aérea, no entanto nas espigas foi verificado uma maior concentração de nitrogênio, potássio e magnésio para amesma cultivar e uma maior concentra ção de fósforo e cälcio na cultivar lAS 3795. sendo que a con centração de enxofre näo diferiu entre as cựivares.

$$
\text { BAKER E TUCKER (1973) com base em experimento }
$$

realizado em um solo deficiente em nitrogênio éfósforo dos EuA obtiveram em plantas com 43 dias de idade a máxima concen- 
tração de nitrogênio, fósforo e potássio, com valores de $5 \%$, $0,46 \%$ e $2,7 \%$, respectivamente.

os fatores que mais influenciam os teores de micronutrientes na matéria seca das plantas, são a sua disponibilidade no solo, indice de pH, umidade, aeração do solo, temperatura do solo e interação entre nutrientes (LUCAS E KNE ZEK, 1972). Os micronutrientes que compõe o grão são provenientes das reservas da planta, principalmente das folhas e o mecanismo de transporte poderá ser influenciado pelas deficiências no suprimento de água (GREGORY et alii 1979 ).

$$
\text { GULATl et alii (1980) estudando na india em ca }
$$

sa de vegetação a influência de três diferentes lâminas de ägua $(1,2 ; 1,5$ e $2 \mathrm{~cm})$ e concentração de boro no solo, sobo teor deste nutriente na matéria seca da planta de trigo, veri ficaram que a concentração na planta é fortemente influenciada pela disponibilidade de água. Em média, na maturação a planta de trigo acumulou 151, 183 e 212 ppre de boro, respecti vamente para as três lâminas d'água estudadas.

Através da literatura verifica-se que os micro nutrientes mais estudados na nutrição do trigo são ferro, zin co, manganês, cobre e boro, os quais são encontrados em maior teor na matéria seca.

Como as concentrações de micronutrientes naplan ta atingem niveis baixos e a produtividade media da. cultura É baira, as reservas do solo, normalmente säo suficientes para o suprimento da planta (MALAVOLTA et alik, 1974). 
A concentração de micronutrientes em plantas de trigo foi estudada em solo arenoso da India por BRAR E SEKHON (1978) verificando que as plantas na fase vegetativa atingiram 30,3 ppm de zinco, 4,8 ppm de cobre, 87 ppm de ferro e 153 ppm de manganês.

SINGH et alii (1980) estudando na india, niveis criticos de zinco para produção de trigo em um solo de aluvião com 5,37 a 0,45 ppm do nutriente, verificaram que a planta armazena aproximadamente $17 \mathrm{ppm}$ no tecido. Nestas mes mas condições é relatado que o nivel crítico de zinco no teci do é de $24,5 \mathrm{ppm}$, considerando-se uma produção reíativa. de $90 \%$.

Entre os micronutrientes mais estudados em nutrição de trigo, o cobre é o que se apresentá em menor concen tração na planta. Comprovando esta afirmativa, ROBSON et alii (1984) conduzindo experimento sobre efeito de estresse hídri. co em casa de vegetação, na Austrälia, concluíram que a concentração critica nas folhas é de $1,3 \mu g / g$ de matéria seca. Em condições de campo os autores detectaram a máxima concentração nas folnas novas em plantas com 33 dias de idade $(4,4$ ppm) e a mínima na maturação $(0,7 \mathrm{ppm})$.

Para estudar a concentração de nitrogênio e fồsforo nas cultivares "plainsman V", "Newton" e "larned" em três estádios do ciclo vegetativo, FJELL et alii (1984) reali zaram experimento em Kansas-EUA, durante dois anos consecutivos. O maior teor de nitrogênio e föstoro nas tiés cultiva- 
res foi verificado no estädio do perfilhamento, onde a cultivar que mostrou maior teor de nitrogênio foi a "plainsman v" e ofósforo armazenou igual teor em todas. No entanto, no es tádio de maturação as três cultivares não diferiram nos teores de nitrogênio e fósforo nos dois anos de estudo, sendo que no final do ciclo a cultivar "plaisman y" acumulou os maio res teores de nitrogênio e fósforo no grão.

$$
\text { cox et alii (1985), trabalhando na Califórnia, }
$$

EUA, para verificarem a influência da varią̧ão genética no acúmulo de matéría seca e nitrogênio nas cultivares de trigo mexicanas "Anza" e "Cajene 71" e 96 linhagens híbridas oriundas destas, mostraram que existem diferenças de comportamento entre as cultivares e seus híbridos. Nafase da floração a cultivar "Anza", acumulou maior quantidade de matéria seca do que a "Cajene $71 "$, no entanto na maturaça ocorreu o inver so. Com relação ao nitrogênio na maturação o grão continha $2,77 \%$ e $2,43 \%$, respectivamente na cultivar "Cajene $71 "$ e "Anza", não mostrando diferenças em ambas durante a fase da floração.

$$
\text { GALRÃO \& SOUSA (1985) estudando nutrição de }
$$

trigo em um solo orgânico da região do cerrado brasileiro analisaram a folha bandeira ca planta na fase da floração e verificaram que os teores de nitrogênio, potássio, cälcio, magnésio, ferro e manganês são $3,80 \% ; 1,62 \% ; 0,47 \% ; 0,47 \% ; 123,5$ ppm e 106,5 ppm, respectivamente. Estes valores foram superiores sos encontrados no grão na fase de maturação. No entan 
to os teores de fósforo e zinco foram encontrados em maior quantidade no grão e nos de cobre não diferiram entre si.

o estudo da nutrição de trigo em solo Cambissoloälico no Estado de São Paulo, Brasil, realizados por BATAGLiA et alii (1985) com as cultivares mexicana "Siete Cerros" e "Alondra" e a cultivar brasileira "IAC 5-Maringä" mostra diferenças na concentração de nutrientes entre as cultivares. A pesquisa mostra ainda que as diferenças entre as cultivares são variáveis em cada ano de cultivo. A cultivar "IAC-5 Maringā" acumulou mais nitrogênio, potássio, cálcio, magnésio, enxofre, cobre e zinco do que as demais, no entan to a cultivar "Siete Cerros" àcumulou mais fósforo.

$$
\text { GRAHAM et alii (1985) visando determinar os ni- }
$$
veis críticos de manganês para produção de grãos, verifićaram que os teores na matéria seca são influenciados pelas con dições climāticas e diferenças genéticas de cada cul.tivar. Mos traram que até uma determinada produção de matēria secca por ärea hā um aumento na concentração de manganês, sendo o nível adequado de $11 \mathrm{ppm}$. No entanto no colmo, aos 37 dias de idade foram encontrados 35 ppm e em material produzido em solos àcidos do sul da Austrália normalmente atinge 60-100 ppm.

o conhecimento sobre o potencial de produção dé grãos das diferentes cultivares, a extração e a exportação de nutrientes é importante para poder-se estabelecer os melho res niveis de adubação e formas de apliçação.

McNEAl et ali i (1968) trabalhando em condiços 
de campo em Montäna, EUA, com seis cultivares americanas e a brasileira "Fronteira", sob condições de irrigação, constata ram haver diferenças de produção de matēria seca e concentra ção de nîtrogênio. Em média as culttivares irrigadas acumu- laram o dobro de nitrogênio, no entanto nesta condição exportaram pelo grão $66 \%$ do $N$ total e $75 \%$ quando não irrigadas.

A produção de grãos é influenciada pelos componentès da produção e para avaliar este comportamento, DAY $\varepsilon$ INTALAP (1970), SHIMSHI \& KAFKAFI (i978) e SHARMA et ali i (1981), realizaram experimentos no Estado de Arizona-USA, India e. Israel, respectivamente, incluindo tratamentos com déficit hídrico sobre a planta e concluiram que a medida que cres c.ia a deficiência, havia redução do nümero de perfilhos/planta, número de grãos/espiga e peso de grãos.

Na região do Planalto Central brasileiro em so los originariamente de vegetação de cerrados onde chuvas são escassas na época de cultivo de trigo, SILVA et alii mostraram que com o uso da irrigação as cultivares brasileiras e estrangeiras atingem rendimentos de até $3000 \mathrm{~kg} / \mathrm{ha}$, pre dutividade 3 vezes superior a média nacional (TOMASIN!, 1982). Em concordância com estes resultados, SILVA et alii (1982) e CALHEIROS et alii (1986) obtiveram em solcs de alta fertilidade e com chuvas escassas, no sul do Estado de Mato Grosso do Sul, Brasil, com o uso da irrigaçäo por aspersão, rendimen tos médios com cultivares locais até $3036 \mathrm{~kg} / \mathrm{h} a$, enquanto em condições de sequeiro o rendimento não ultraprassou de $1130 \mathrm{~kg} / \mathrm{ha}$. 
SINGH \& AGGARWAL (1976) estudando três disponibilidades de ägua, $30 \%, 50 \%$ e $70 \%$ da capacidade de campo em um solo arenoso-argiloso da região àrida da lndia, concluíram que os níveis de irrigação afetaram a produção de gräos, - no entanto a produção de matéria seca determinada na emergên cia da espiga não foi anfluenciada.

Atravēs de estudos realizados no Canadá, CAMPBELL et alii (1977) com tratamento irrigado, precipitação natural e sete doses de nitrogênio, aplicados na cultivar "Maniton", verificaram que os componentes de rendimento, como o nümero de plantas/ärea, nūmero de perfilhos/planta, nümero de grãos/espiga e peso de grãos são influenciados pelo fornecimen to de nitrogênio e suprimento de ägua. No entento relataram que o regime de āgua não afeta a concentração de nitrogênio na parte aèrea da planta e o acūmulo total é fortemente influenciado pela irrigação, pois este é função do fornecimento de àgua.

Utilizando quatro tratamentos com irrigação; testemunha, uma, duas e três irrigações durante o cicelo da planta, em um solo arenoso da India, SINGH et alii (1979) verificaram que a produção de palha e grãos cresceu com o nümero de irrigações. O teor de fösforo no grāo roi altamente in fluenciado pelas irrigações, assim como o acümulo de nitrogénio na parte aérea da planta.

Através de trabalho semelhante ao anterior, SHIMSHI E KAFKAFi (1978) estudando irrigaça suplementar, com 
uma, duas e três vezes durante o ciclo da cultura, verificaram uma maior produção de grãos com o tratamento aplicado logo após a germinação mais a aplicação na eníssão da espiga, seguido do trátamento aplicado somente após a germinação.

MUZILLI \& HOEPNER (1981) através de estudos com a nutrição do trigo realizados no Estado do Paraná, mostraram que a espécie tem crescimento lento até atingir o estādio do perfilhamento, intensificando a partir dai até o estâdio de grão leitoso, sendo que posteriormente só há um pequeno acūmulo de matéria seca. O nitrogênio, fósforo e potás sio são acumulados em maior quantidade até o emborrachamento, respectivamente $68 \%, 65 \%$ e $90 \%$ do total encontrado na planta, atingindo o máximo no estádio de grão leitoso.

- A absorção de macronutrientes pela planta, con forme GARGANTINI \& BLANCO (1973) e KARLEN \& WHITNEY (1980) é feita em quantidades que obedece a seguinte ordem: $K>N>$ $>\mathrm{Ca}>\mathrm{P}>\mathrm{S}>\mathrm{Mg}$, no entanto a exportação stes pelo grãonão obedece a mesma ordem, sendo os mais exportados o nitrogênio, câlcio, magnësio, enxớre, potássio e fúsfaro. 
18.

\section{MATERIAL E MÉTODOS}

\subsection{LOCAL DE EXECUGAO DO ENSAIO}

0 ensaio foi conduzido no ano agrícola de 1985 em ärea pertencente a Unidade de Execução de Pesquisa de $\pi_{m}$ bito Estadual da Empresa Brasileira de Pesquisa AgropecuäriaEMBRAPA em DOURADOS-MS, localizada a 220141 de latitude sul e -a 54049' de longitude oeste, a uma altitude média de $452 \mathrm{~m}$.

Segundo a classificação de kß̈ppen, o clima ë caracterizado como Cfa, mesotērmico ümido, com verão chuvoso e inverno seco. A média anual de precipitação pluvial é de $1300 \mathrm{~mm}$, sendo que, aproximadamente $75 \%$ ocorrem no periodo ou tubro-abril e $30 \%$ de maio-setembro, periodo mais frio do ano. A temperatura média anual é 22,190 , sendo 28,890 a média das mäximas e 16,7?c a média das mínimas. A média anual da umidade relativa é $74 \%$.

o solo foi classificado pela equipe de pesqui- 
sa do Departamento Nacional de Pesquisa Agropecuária do Depar tamento Nacional de Pesquisa Agropecuária, como Latossolo Roxo distrófico de textura argilosa, fase campo (BRASIL, 1971). os resultados da análise química do solo, rea3izada antes do plantio, são apresentados na Tabela 1 .

Iabela 1. Análise das amostras de solo da áréa utilizada nos ensaios, de 0-20 cm de profundidade.

Componentes

da anàlise
Amostra Amostra

12

\begin{tabular}{|c|c|c|c|c|}
\hline $\mathrm{pH}$ em $\mathrm{H}_{2} \mathrm{O}(1: 2,5)$ & & 6,2 & 6,1 & \\
\hline $\mathrm{Al}^{+3}(\mathrm{~m} . \mathrm{e} . / 100 \mathrm{~g}$ de & solo) & 0,0 & 0,0 & $K C 1,1 N, 1: 10$ \\
\hline $\mathrm{Ca}^{+2}(\mathrm{~m} . \mathrm{e} . / 100 \mathrm{~g} \mathrm{de}$ & solo) & 11,2 & 8,4 & $K C] I N, 1: 10$ \\
\hline $\mathrm{Mg}^{+2}(\mathrm{~m}, \mathrm{e} . / 100 \mathrm{~g} \mathrm{de}$ & solo) & $i, 9$ & 2,0 & $K C\} I N, 1: 10$ \\
\hline$p(p p m)$ & & 2,0 & 1,7 & Mehlich \\
\hline$k+(p p m)$ & & 154 & 124 & Mehlich \\
\hline $\mathrm{Cu}(p p m)$ & & 10,3 & 7,9 & DTPA-TEA 2 \\
\hline $\mathrm{Fe}(p p m)$ & . & 1,2 & 3,3 & DTPA-TEA \\
\hline $\operatorname{Mn}(p p m)$ & & 74,2 & 61,1 & DTPA-TEA \\
\hline $2 n(p p m)$ & & 0,31 & 0,20 & DTPA-TEA \\
\hline C $(\%)$ & & 2,3 & 2,1 & \\
\hline
\end{tabular}

1 Amostra 1 - área do experimento irrigado

Amostra 2 - ārea do experimento sem irrigą̧ão

2 Dietilenotriamino pentacético - Trietanolamina. 


\subsection{INSTALAeÃO DO ENSAIO}

Foram instalados dois experimentos em condições de campo, um com irrigação e outro em condições seque ro. No primeiro experimento foi utilizada a irrigação por as persão convencional. Os aspersores utilizados apresentavam um raio de alcance de $17,6 \mathrm{~m}$, bocais de $5 \times 6,5 \mathrm{~mm}$ de diâmetro, vazão de $4,42 \mathrm{~m}^{3} / \mathrm{h}$, trabalhando a uma pressãa de 3 atmosferas e com expaçamento de $18 \times 18 \mathrm{~m}$, o que proporcionavá uma precipitação média de $10 \mathrm{~mm} / h o r a$. O segundo experimento, em sequeiro, o trigo permanecia no campo durante todo o seu ciclo, na dependênciá exclusiva da àgua da chúva.

Cada experimento foi instalado segundo o esque ma experimental de parcelas subdivididas no delineamento de blocos casualizados com 4 repetições, sendo as prcelas constituidas de duas cultivares e as subparcelas por idades de amostragem.

As cultivares utilizadas foram a BH 1146 , cria da pela antiga Estação Experimental de Bela Horizonte - MG, de porte aito e com tolerância à deficiência hídrica e a IAC 24-Tucuruí, criada pelo Instituto Agromómico de Campinas, de porte baixo com menor tolerância à deficiência hídrica, sendo ambas de ciclo médio. Foram realizadas seis amostragens de plantas, aos $10,30,50,70,90$ e 110 dias após a emergência, correspondendo respectivamente, ao início do perfilhamento, elongamento do colmo, emborrachamerto, floração, 
grão leitoso e maturação. Foi incluída uma sub-parcela adicional para avaliação dos componentes de produção e rendimento de grãos.

O preparo do solo foi feito através de uma ara ção e duas gradagens. A adubação, imediatamente antes do plan tio, foi feita com $20 \mathrm{~kg}$ de $\mathrm{N}$ e $90 \mathrm{~kg}$ de $\mathrm{P}_{2} \mathrm{O}_{5}$ por hectare, à base de sulfato de amônio e superfosfato triplo e misturados com o solo antes da semeadura. Não foi realizada adubação potássica, visto a alta concentração no solo.

A semeadura foi feita no dia 2 de maio, em sul cos com $5 \mathrm{~cm}$ de profundidade, espaçados de $20 \mathrm{~cm}$, sendo ciada sub-parcela constitulda de 4 sulcos com 4 m de comprimento. A densidade de semeadura foi de 400 sementes aptas/m². Em cada amostragem foram utilizados os dois suicos centrais com $3 m$ de comprimento, desprezando-se $50 \mathrm{~cm}$ em cada cxtremidade.

\subsection{CONDUCÃO DO ENSAIO E DETERMinA\&ÃO DOS NUTRIENTES}

Apōs o plantio os dois experimentos, sequeirò e irrigado, receberam uma irrigação de $30 \mathrm{~mm}$ para que a germiną̧ão fosse uniforme. A partir dal, no experimento irrigado, o controle de umidade foi feito através de tensióme tro, instalado a $10 \mathrm{~cm}$ de profundidade até e final do perfiIhamento e a $30 \mathrm{~cm}$ até a maturaçäo, sendo que as irriçações eram realizadas sempre que a tensão da ägua atingia a 0,5 atin. 
de pressão, com uma precipitação de $30 \mathrm{~mm}$. As ocorrências de chuvas, temperaturas, irrigações efetuadas e amostragens estão apresentadas na Figura 1 e Tabela 2 .

A coleta de plantas para determinação da produção de matéria seca e os nutrientes foi feita entre plantas competitivas, mediante o corte do colmo, junto à superfície do solo. Em cada amostragem foram coletadas 20 plantas por subparcèla, com excessão da primeira amostragem, lo dias de idade, em que foram coletadas 50 plantas. As plantas coletadas aos 90 e 110 dias de idade foram divididas em 5 partes: colmo, folha, folha bandeira, grão e espiga para determinação das variáveis anteriormente relacionadas.

Após a coleta, conforme é recomendado por SARRUGE \& HAAG (1974), o material era lavado para descontaminação mineral e submetido a secagem a estufa, com circulaçãofor çada de ar, à temperatura de 70:C, até peso constante. Apös a secagem, as amostras foram moídas, homogeinizadas e acondicio nadas em saco de papel para posterior realização das anälises.

As anälises foram realizadas no laboratōrio de Nutrição de Plantas do Departamento de Química da ESALQ/USP em Piracicaba. O nitrogênio foi determinado pelo método Kjeldahı; o fósforo por colorimetria; o potässio por fotometria de chama; o cálcio, magnésio, cobre, ferro, manganés e zinco por espectrofotometria de absorção atômica e o enxofre por gravimetria, segundo processos descritos por SARRUGE \& HAAG (1974). o boro roi determinado pelo mëtodo da Azometina-H, conforme descreve MAZAHERI (1976). 


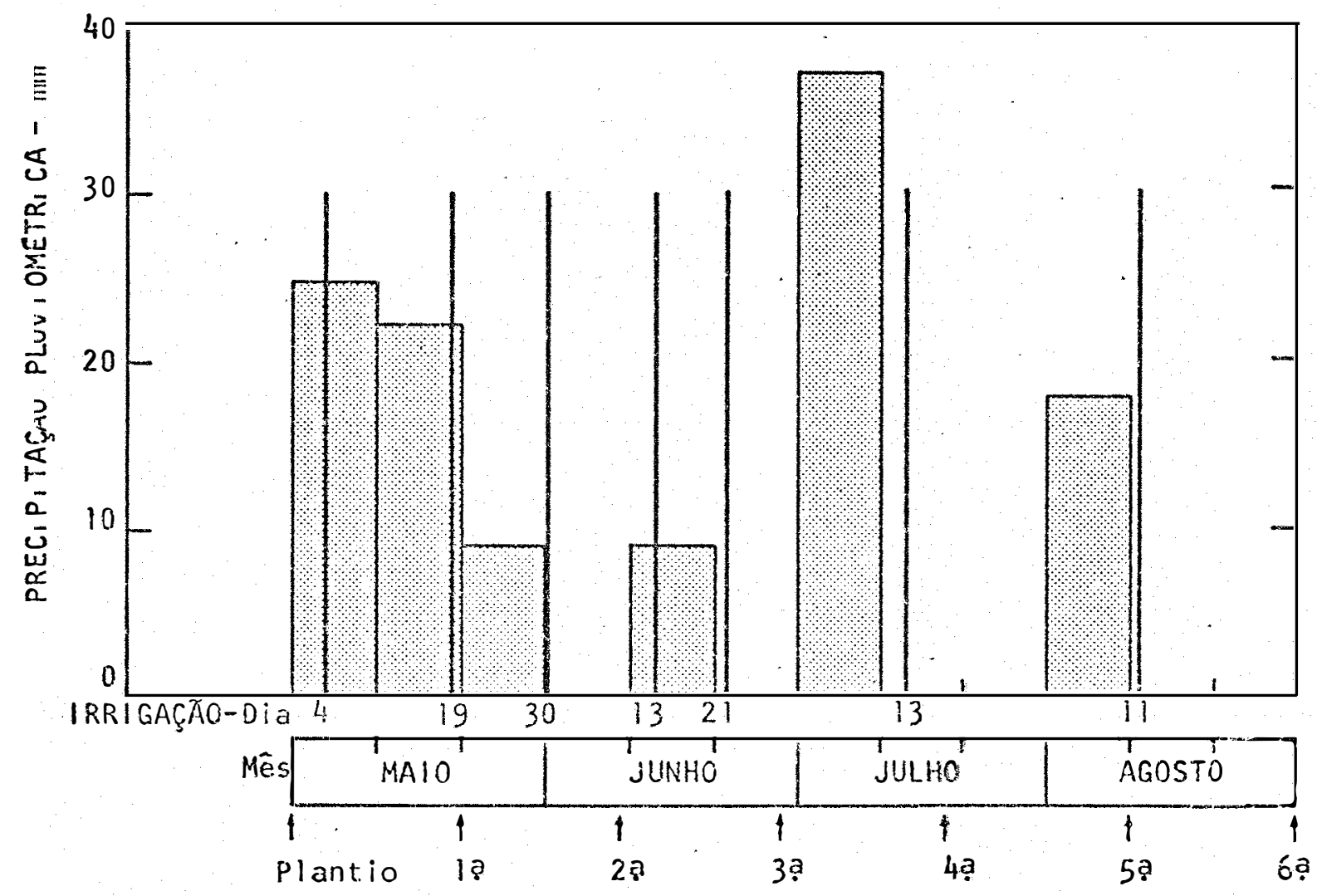

\begin{tabular}{ccl}
\hline AMOSTRAGEM & DATA & ESTADIO DA PLANTA \\
\hline $1 a$ & 20.05 .85 & Inicio perfilhamento \\
$2 a$ & 09.06 .85 & Elongamento \\
$3 a$ & 28.06 .85 & Emborrachamento \\
$4 a$ & 18.07 .85 & Floração \\
$5 a$ & 10.08 .85 & Grão leitoso \\
$6 a$ & 30.08 .85 & Maturação \\
\hline
\end{tabular}

Figura 1. Precipitação pluviomêtrica, irrigações realizadas no experimento e amostragens efetuadas durante o ciclo da cultura. 


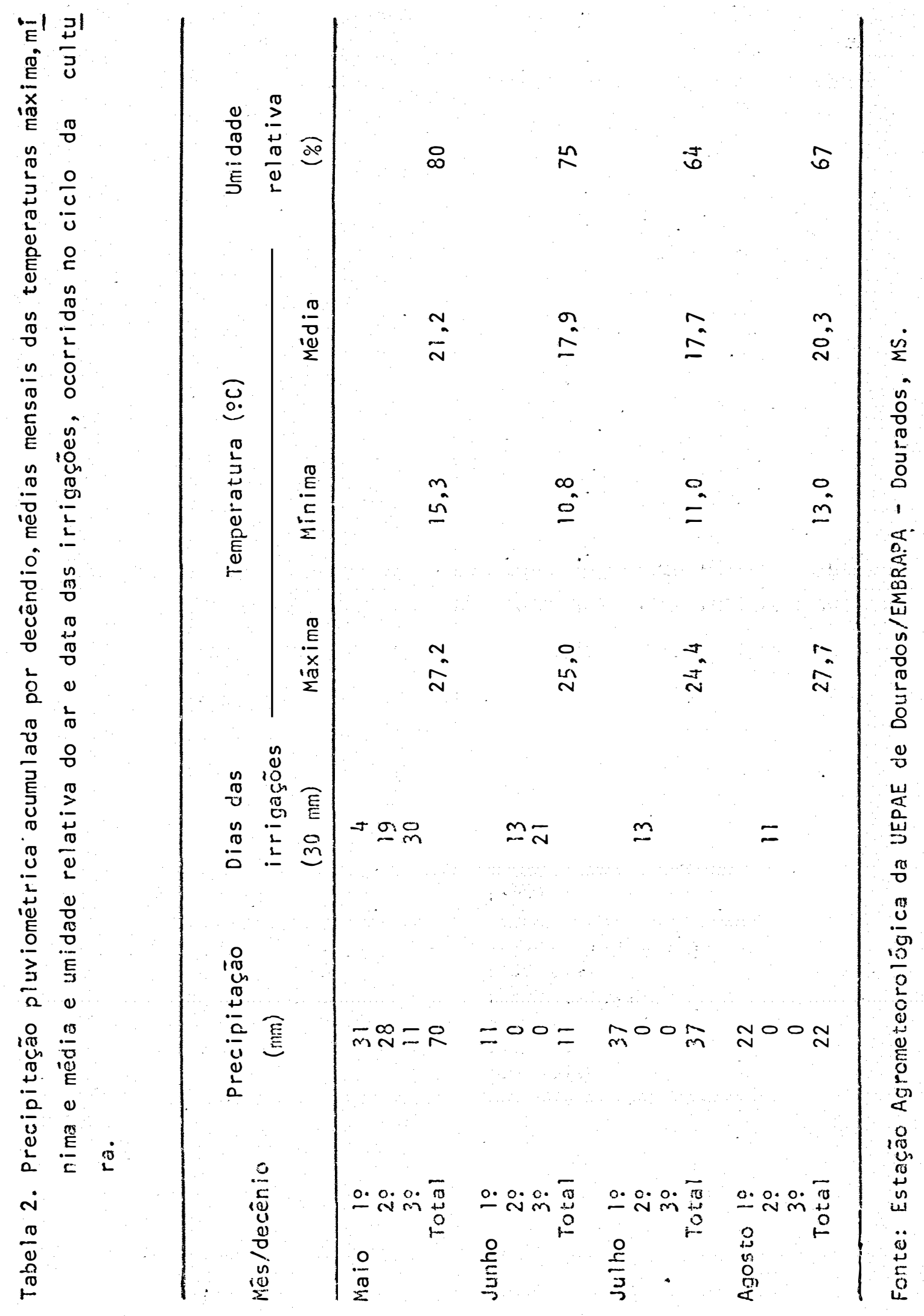




\subsection{ANALise estatIStica}

Para a anālise da produção de matéria seca e teor de nutrientes da planta inteira, foram tomadas as disponibilidades de água e cultivares e combinados um a um e submetidos a análise de variância de regressão considerando-se as idades de coleta como pontos determinantes das curvas, em cada nutriente e produção de matéria seca. Para análise das idades de máxima produção de matéria seca e acūmulo de nutrientes foram considerados os valores observados.

Nos dados das partes da pianta, produção de grãos, peso de mil sementes e peso do hectolitrofoi aplicada a anālise da variância de acordo com o modelo estatístico já mencionado, sendo as médias, quando necessārio, comparadas pe 10 teste Tukey a $5 \%$ de probabilidade.

A análise estatística foi realizada no Centro - de Informática na Agricultura, ESALQ/USP em Piracicaba, SP 
26.

\section{RESULTADOS E DISCUSSÃO}

\subsection{Desenvolvimento da planta}

O desenvolvimento das plantas, avaliado pela produção de matéria seca da parte aérea e produção de matéria seca por ärea, á apresentado na figura 2 e Tabela 3.

No regime irrigado as duas cultivares apresentaram produção de matéria seça por planta e produção de maté- ria seca por área superior ao regime de sequeiro. Para estes dois parâmetros a cultivar BH 1146 apresentou maiores valores aos 90 dias de idade. A cultivar IAC 24-Tucuruí em se queiro, apresentou o máximo de produção de matéria seca na mesma idade, no entanto, quando irrigada a produção máxima fo: verificada na maturação final (Tabela 3 e Figura 2b).

iras duas disponibilidades de água o nūmero de plantas por área apresentou valor máximo no início do ciclo, sendo que no decorreir do desenvolvimento das plantas, este nú mero foi reduzindo-se, atingindo o minimo na maturação final 


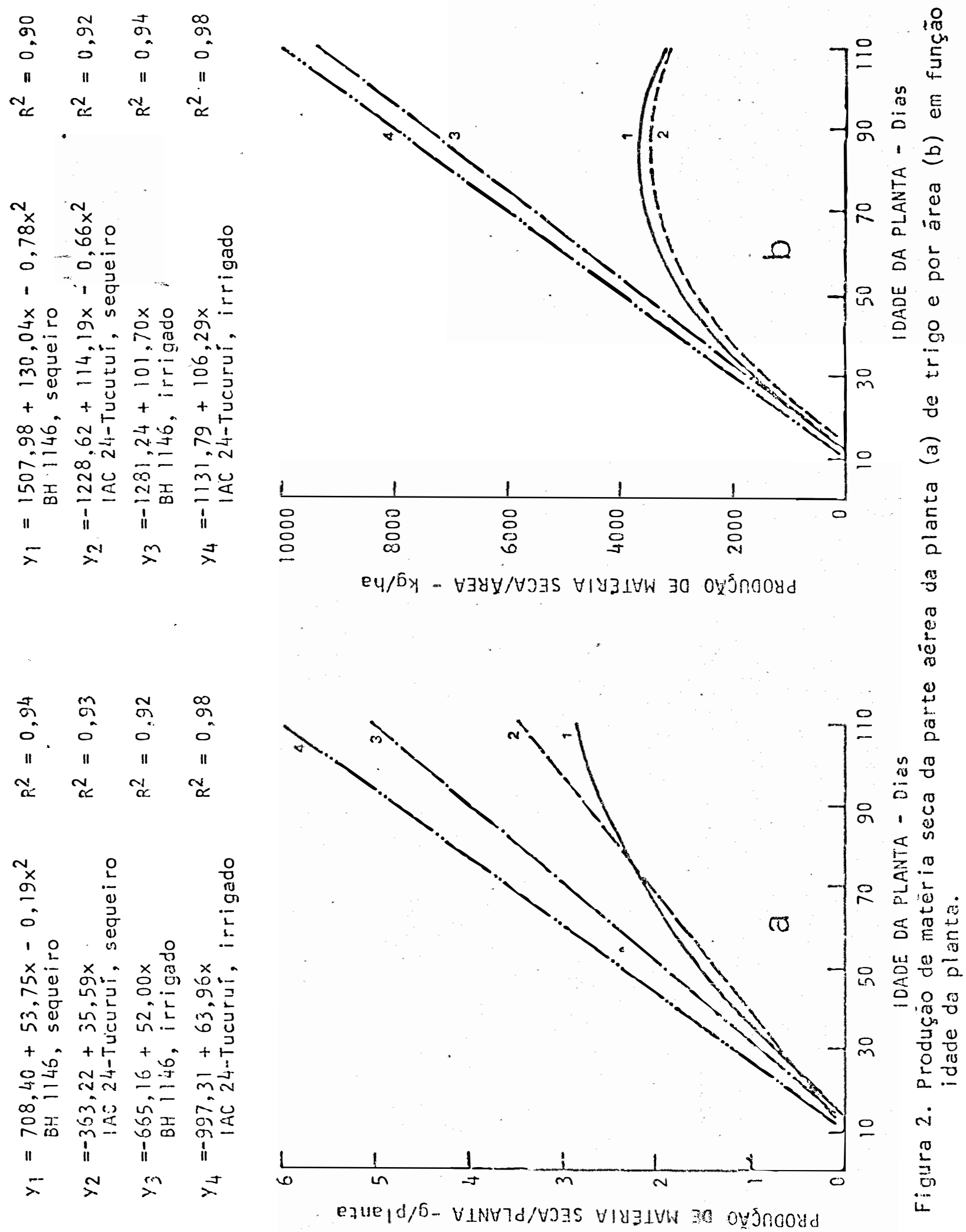




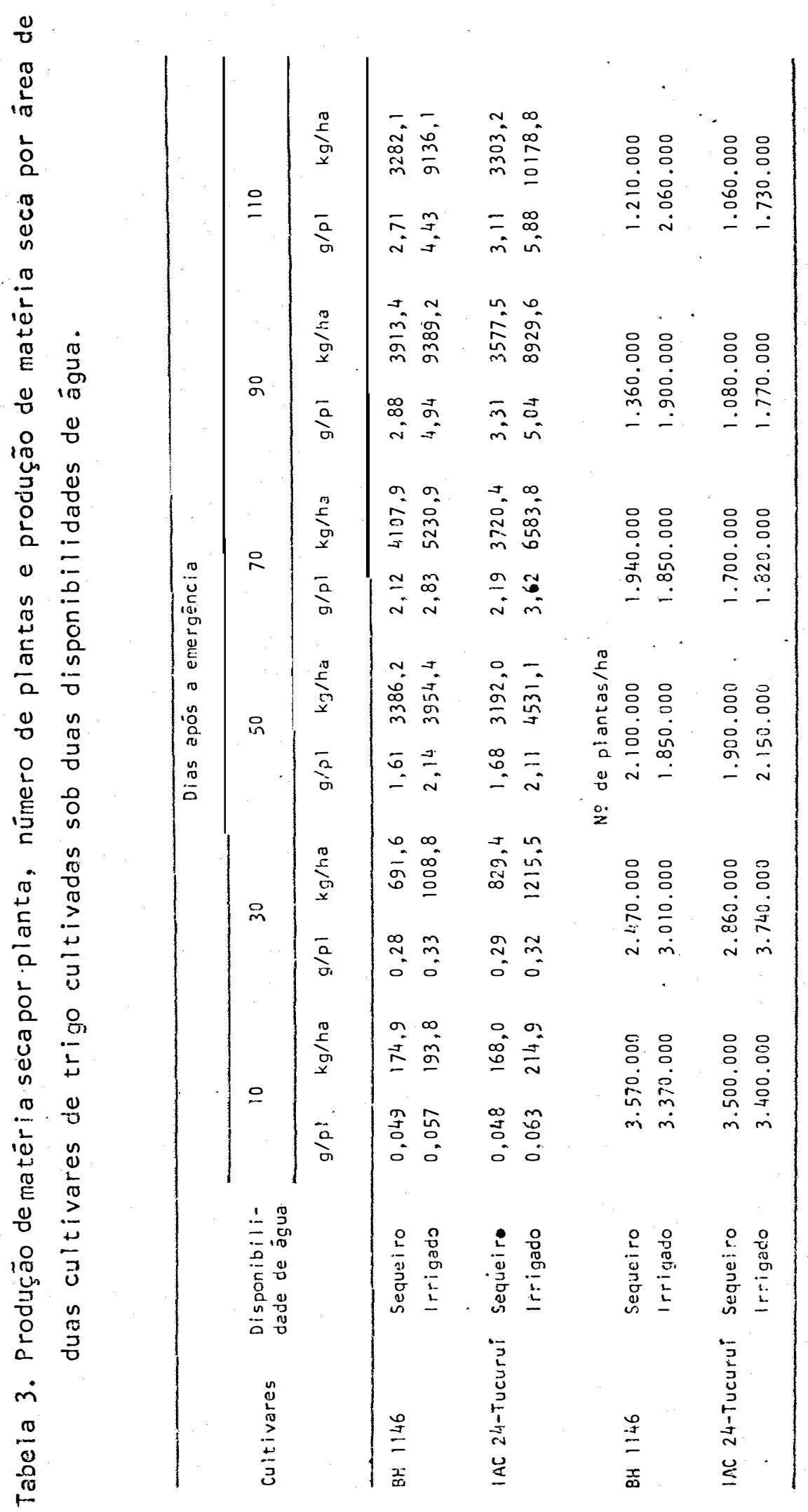


(Tabela 3 e Figura 3). No regime irrigado, tanto a cultivar BH 1146 como a IAC 24-Tucuruí, apresentaram menor redução no nümero de plantas. A redução na população de plantas, verificada bo regime de sequeiro foi devida a deficiencia hídrica.

Em experimento semelhante, SHARMA et ali i (1981), estudando irrigação em trigo com turnos de rega sempre que a tensão de àgua no solo atingia 0,$5 ; 1,2$ e 4 atmosferas de pressão, mostrou que com o aumento dos intervalos houve acentuada redução no número de plantas/área e nümero de perfiIhos. KARLEN E WHITNEY (1980) mostram que as plantas de trigo acumulam um mínimo de matéria séca àté a elongação do colmo, crescendo até atingir valores māximos na maturação fisiológica e depcis mostrando decrēscimo até a maturação final. Coniportamento semelhante ao observado pelo ültimo autor foi mostrado pelas duas cultivares em regime de sequeiro na presen te pesquisa e no regime irrigado verificou-se comportamento crescente desde o início do ciclo até a maturação final.

$$
\text { BOATWRIGHT E HASS (1961) e PAGE et ali }
$$

conduziram experimentos em condições de campo e relatam que. a planta atinge o māximo de produção de matéria seca durante o śstádio de emissäo da espiga, havendo a partir daf um decréscimo nas diversas partes da planta e um acréscimo na matéria seca dos grãos. O presente estudo discorda em parte dos resul. tados obtidos pelo autor, pois a maior produçäo de matëria se ca foi obtida no estádio de grão leitoso, comexcessão da cul- 
30.

$$
\begin{aligned}
& y_{1}=384,92-4,30 x+0,02 x^{2} \quad R^{2}=0,96 \\
& \text { BH } 1146 \text {, seque i ro } \\
& y_{2}=402,39-4,93 x+0,02 x^{2} \quad R^{2}=0,98 \\
& \text { IAC. 24-Tucuruí, sequeiro } \\
& \begin{array}{rl}
y_{3}= & 319,02-1,41 x \\
B H & 1146, \text { irrigado }
\end{array} \\
& y_{4}=414,43-4,35 x+0,02 x^{2} \quad R^{2}=0,81 \\
& \text { IAC 24-Tucuruí, irrigado }
\end{aligned}
$$

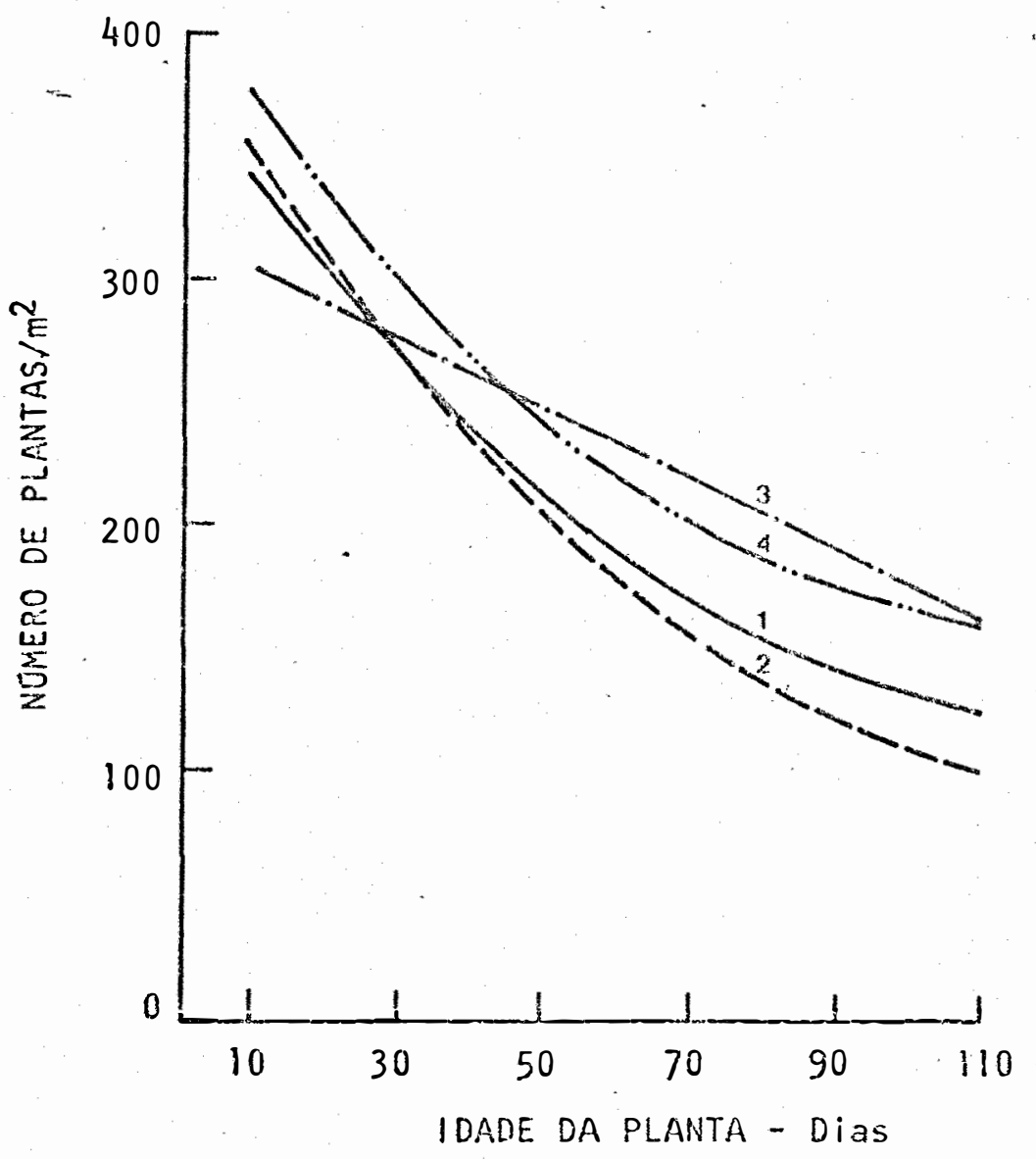

Figura 3. Número de plantas por área de duas cultivares de trigo, cultiva

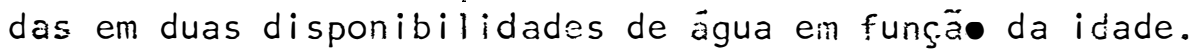


tivar IAC 24-Tucuruí com irrigação que apresentou máximo acúmulo na maturação final. Estudando a nutrição da planta de tri go em vasos GAMA (1977a), obteve uma produção máxima de matéria seca de $8,14 \mathrm{~g} / \mathrm{planta}$, sendo que, WALDREN \& FLOWERDAY (1979) em condições de campo durante três anos consecutivosobtiveram uma produção máxima de matéría seca por planta de $7,61 \mathrm{~g}$, observando-se assim, que estes valores são muito superiores ao máximo atingido na presente pesquisa.

\subsection{Concentracão e acúmulo de nutrientes ina planta}

\subsubsection{NITROGEN1O}

A máxima concentração de nitrogênio na planta

foi verificada no inicio do ciclo, para as duas cultivaresnas duas disponibilidades de água. O acụmulo máximo, considerando a matéria seca produzida por planta, ocorreu no estádio de grão leitoso, com excessão da cuitivar IAC 24-Tucuruí, quando irrigada, que apresentou acúmulo máximo deste nutriente no final do cíclo. A concentração de nitrogênio nas duas cultiva res não mostrou diferenças ao longo do ciclo em cada uma das disponibilidades de água, no entanto, o ácümulo apresentou maiores valcres para as cultivares quancio cultivadas sot irri gação, sendo que à $I A C$ 24-tucuruí acumulou máior quantidade nas duas disponibilidades de água (Figura 4 e Tabelas 4 e 5). 

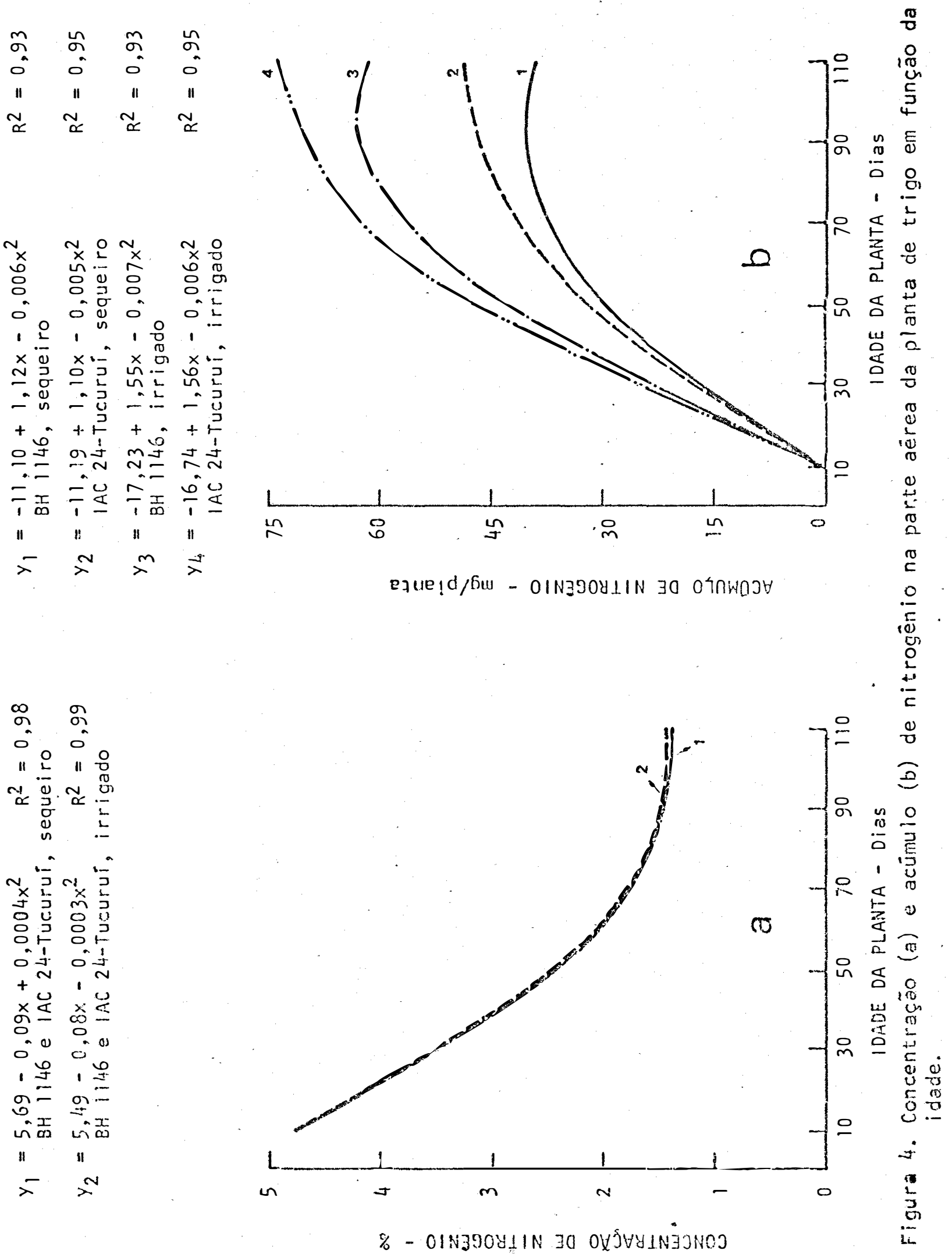


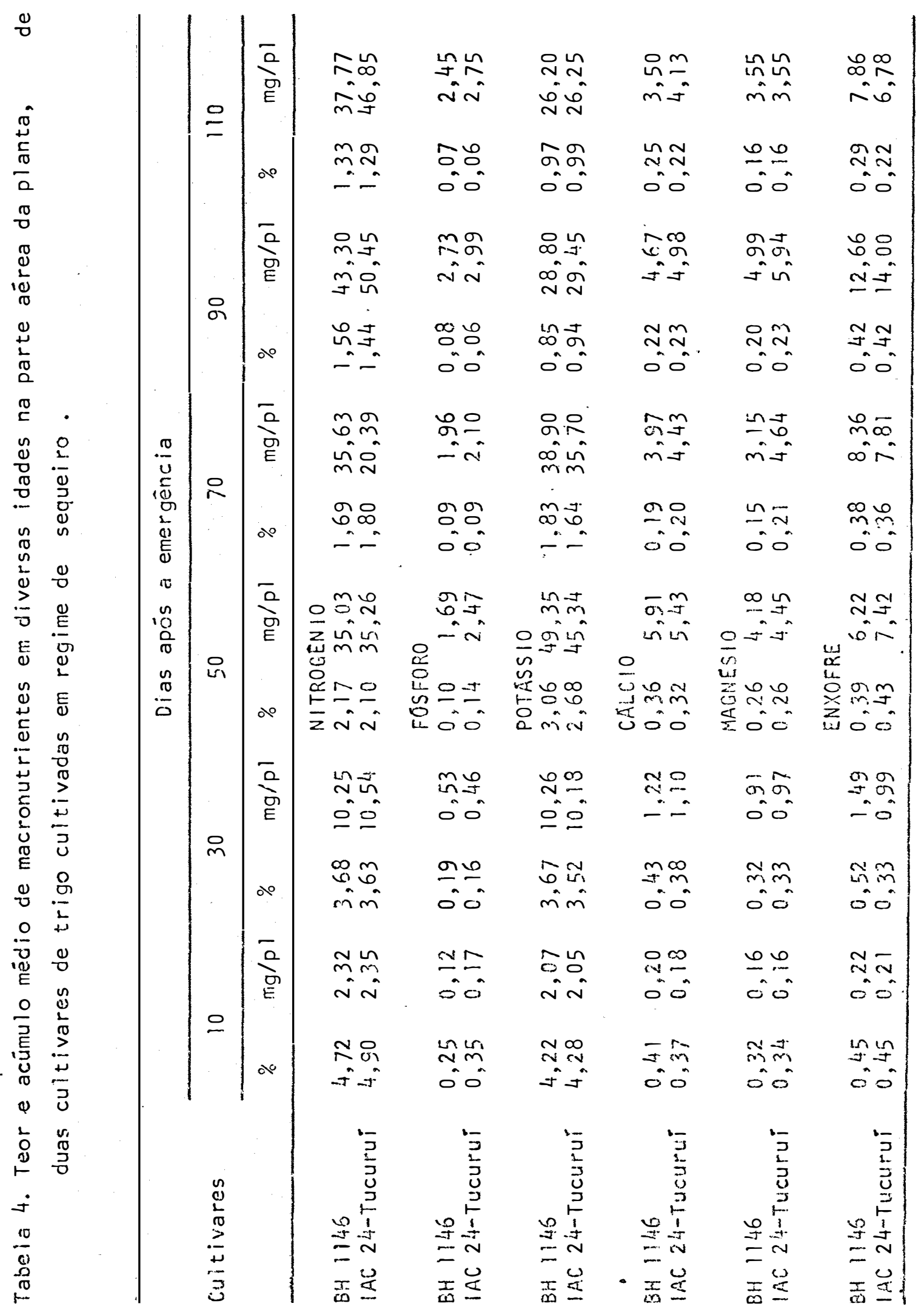




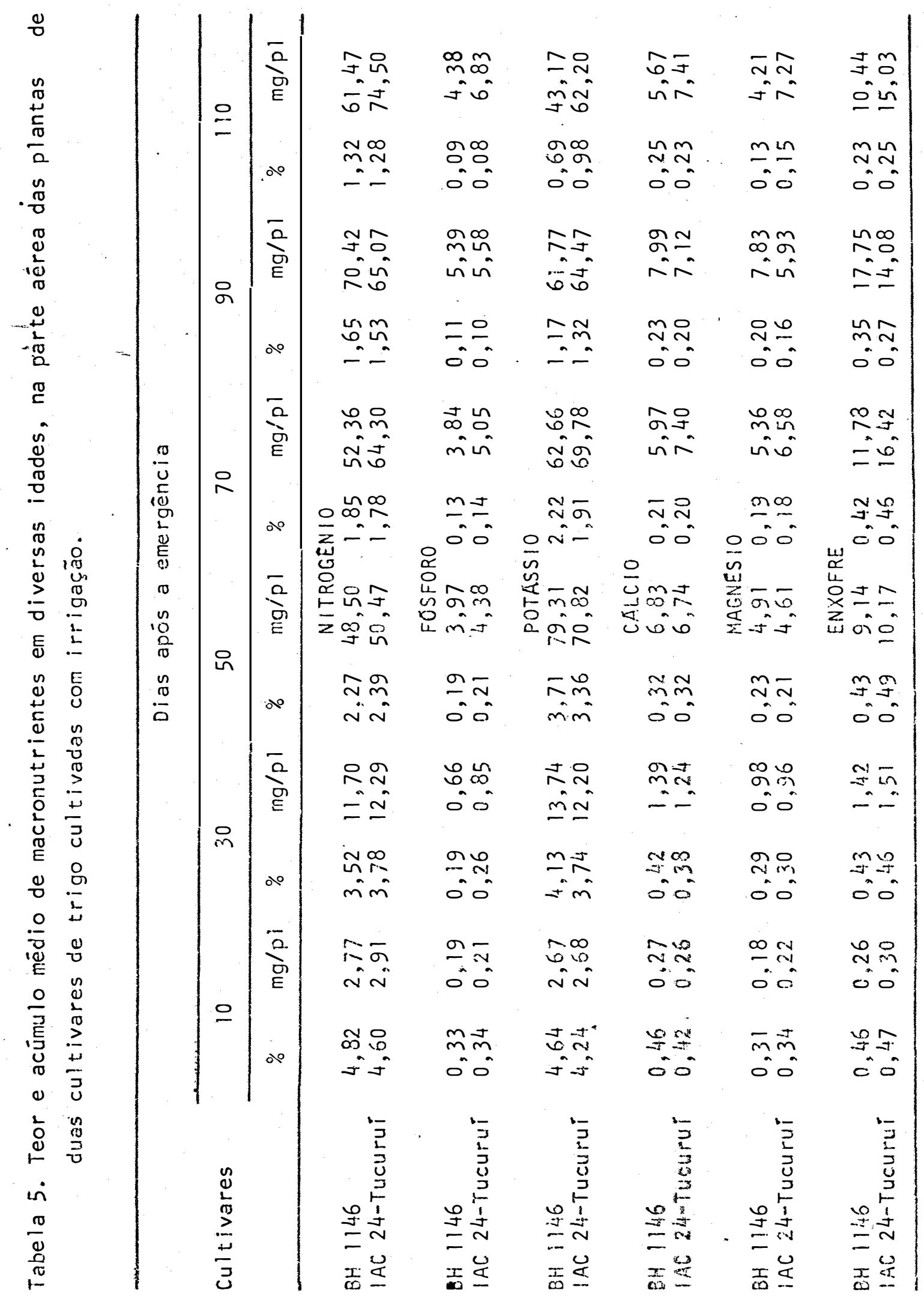


Apesar de nos primeiros dias de idade, o acümulo não ter diferido em todas as situações, na maturação o maior acúmulofoi constatado no regime irrigado para ambas as cultivares.

As diferenças verificadas no acūmulo de nitrogênio, entre as cultivares e disponibilidades déăgua são em função das diferenças de produção de matēria seca/planta, pois conforme mostra a Figura 4 a, não ocorreram diferenças na concentração deste nutriente entre os fatores mencionádos. A este respeito, GASSER \& THORBURN (1972); trabalhando em condições de campo, com e sem irrigação, mostram que o suprimento de àgua influi diferentemente sobre a concentração de cada nu triente na planta. No caso particular do nitrogênio foi verificada uma redução no teor com os tratamentos com irrigação. A concentraçãó de nitrogênio determinada por BAKER \& TUCKER (1973) em plantas de trigo, cultivadas, em un solo deficiente neste nutriente e em fósforo, atingiu o valor máximo de $5 \%$, aos 43 dias de idade.

CAMPBELL et a ! i i (1977) estudando o efeito de fertilizantes nitrogenados e limidade do solo, sobre a concentração de nitrogênio na parte aérea do trigo, constataramque a concentração do nutriente decresce com o tempo, apresentando $5,39 \%$ no estádio de 3 fol has e $0,50 \%$ na maturação e que o maior decréscimo ocorre à partir do perfilhamento. Por outro lado, o autor relata que o regime de ägua não altera a concẹn trą̧ão de $N$ na planta. 
O acúmulo de nitrogênio apesar de crescente du rante todo o ciclo nas duas cultivares e disponibilidades de água, mostra que em condições de sequeiro a cultivar BH 1146 e IAC 24-Tucuruí, aos 50 dias de idade jä haviam absorvido $92,7 \%$ e $75,2 \%$ respectivamente do $N$ acumulado no final do ciclo e em regime de irrigação na mesma idade o acúmulo foi de $78,9 \%$ e $67,7 \%$ respectivamente para as duas cultivares. Este fato comprova a necessidade da aplicação da adubação nitrogenada com antecedência ào estádio do emborrachamento, como nor malmente é feito.

\subsubsection{FOSFORO}

A máxima concentrą̧ão de fösforo nas duas cultivares, em ambas as disponibilidades de água ocorreu no inicio do desenvolvimento da planta, decrescendo a partir daí estabilizando-se a partir dos 70 dias de idade. 0 acúmulo de fósforo na parte aërea da planta foi crescente ao longo do ci clo nas cultires estudadas independente da disponibilidade de água. Em regime de sequeiro o ácúmulo deste nutriente foi semelhante para as duas cultivares ao longo do ciclo. No entanto, com uso da irrigação houve diferença com relação äo acúmu 10 deste nutriente, mostrando que a cuitivar laC 24-Tucuruí, acumulou $36 \%$ a mais em relaçäo a EH 1146, no final do ciclo (Figura 5 e Tabeias 4 e 5). Nas duas disponibilidades de água apesar das cultivares terem apresentado ecamulo crescente, até 


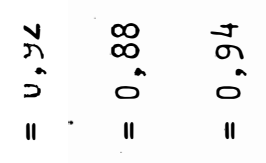

도유 요

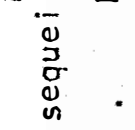

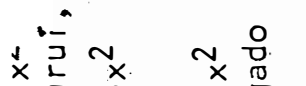

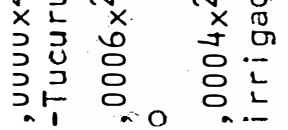

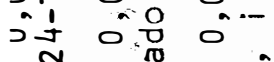

1 1 告

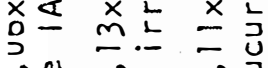

ว0 0.

$+\frac{0}{+-1}+\frac{0}{a}+\frac{1}{2}$

- =

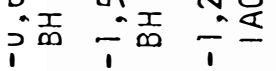

" i $\|$

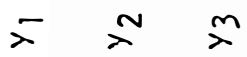

i $\begin{array}{lll}\text { nू } & \text { a } & \text { के }\end{array}$

$\begin{array}{llll}\| & \| & \| & \| \\ \dot{x} & \approx & \propto & \propto\end{array}$

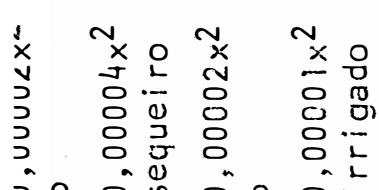

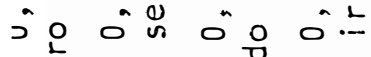

$+\frac{1}{0}+\cdots+\frac{0}{0}+\cdots$

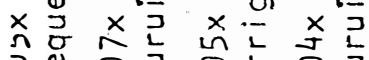

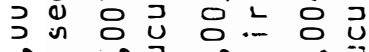

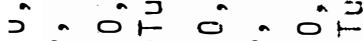

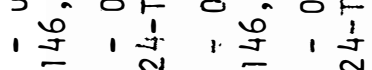

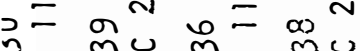

ñ mu ma mu

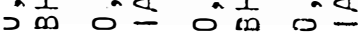

\| " I ।

$\pi \stackrel{n}{x} \pi$
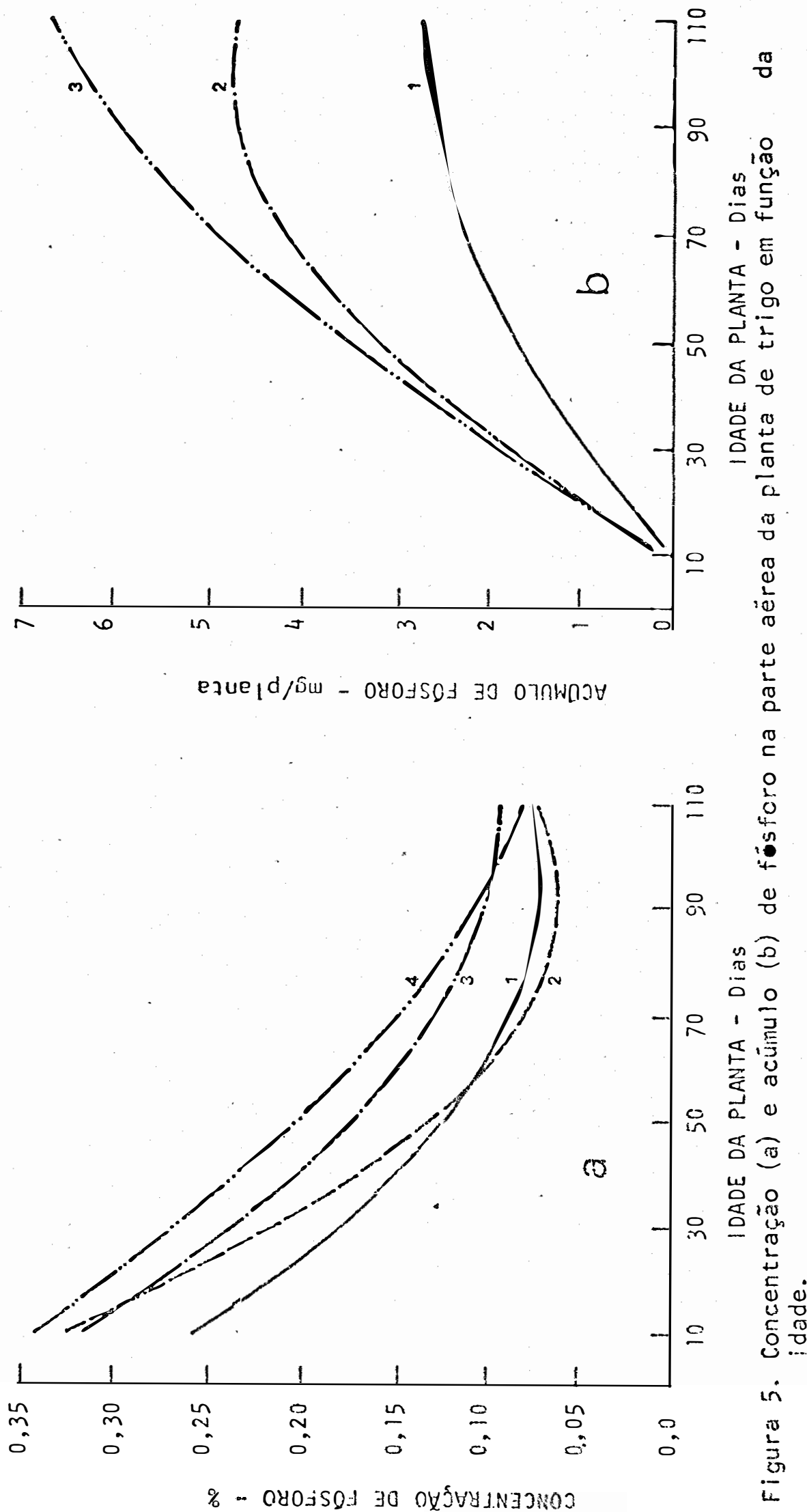
os 30 dias de idade este crescimento foi lesto, acentuando-se a partir daí, sendo que, em "sequei.ro" o máximo acúmulo para as duas cultivares e para a BH 1146 sob irrigação ocorreu aos 90 dias de idade, no entanto a cultivar IAC 24-Tucuruí, irrigada, apresentou o máximo acúmulo na maturạ̧āo final.

No regime de sequeiro, até os 30 dias de ida de as cultivares, BH 1146 e IAC 24-Tucurui, acumularam $21,6 \%$ e $16,7 \%$ de fósforo, respectivamente e em condições de irrigação $15,1 \%$ e $12,4 \%$, respectivamente. Este fato mostra a necessidade do suprimento adequado deste nutriente para a planta até o final do ciclo, principalmente quando os cultivos forem feitos com irrigação, sendo que neste particular, deve-se res saltar que aos 90 dias de idade a cultivar lac 24-Tucurui ain da precisaria absorver aproximadamente $18 \%$ do $P$ total.

BASSIRI \& NAHAPETIAN, (1977) estudando diferentes concentrações de macronutrientes na planta e suas rela ções, em condiçōes de irrigação e șequeiro, concluíram que a máxima absorção de $P$ pela planta de trigo ocorreu com irrigação, sendo que o grupo de cultivares estudiadas não mostraram diferenças na concentraçäo deste nutriente, acontecendo o contrário quando as mesmas foram irrigadas. Näo havendo, no entanto, interação entre cultivares e disponibilidade de água. GREgory et alii (1979) eśtudando acúmulo e ditstribuição de nutrientes ria planta de trigo, relatam que o máximo acúmulo dos nutrientes ocorre aos 60 dias de idade que para o fósfo ro o máximo ocorre mais tardiamente, sendo uge o menor acúnu- 
lo no final do ciclo é devido a baixa assimilação de nutrientes em relação ao carbono e senescência de algumas folhas e perfilhos.

\subsubsection{POTASSIO}

A concentração e acúmuio de potássio pelas plan tas de duas cultivares de trigo em diferentes disponibilida des de ägua podem ser vistos na Figura 6 . Nas quatro situaf̧ões estudadas, verifica-se que a concentração de potássio de cresceu linearmente, desde o início do ciclo até a maturação final. No regime de sequeiro a concentração do nutriente apresentou menor valor nas duas cultivares do que com irrigaf̧ão. Nas duas disponibilidades de água a cultivar BH 1146 con centrou maior teor de potássio. No regime de sequeiro o máximo acúmulo de potássio para as cultivares ocorreu aos 50 - dias de idade, não mostrando diferença entre ambas. No tratamento com irrigação, apesar do máximo acúmulo ter ocorrido na mesma idade, houve diferença entre cultivares, sendo que atë o Estádio do elongamento o maior acūmulo ocorreu na cultivar BH 1146 e a partir dai este fato ocorreu com a cultivar IAC 24-Tucurui (Tabelas 4 e 5 ).

A partir do estádio em que houve o máximo acü. mulo de potássio, ocorreli acentuado decréscimo deste nutriente até ofinal do ciclo. Em regime de sequeiro as cultivares BH 1146 e IAC 24-Tucuruí, reduziu 47\% e $42 \%$, respectiva- 

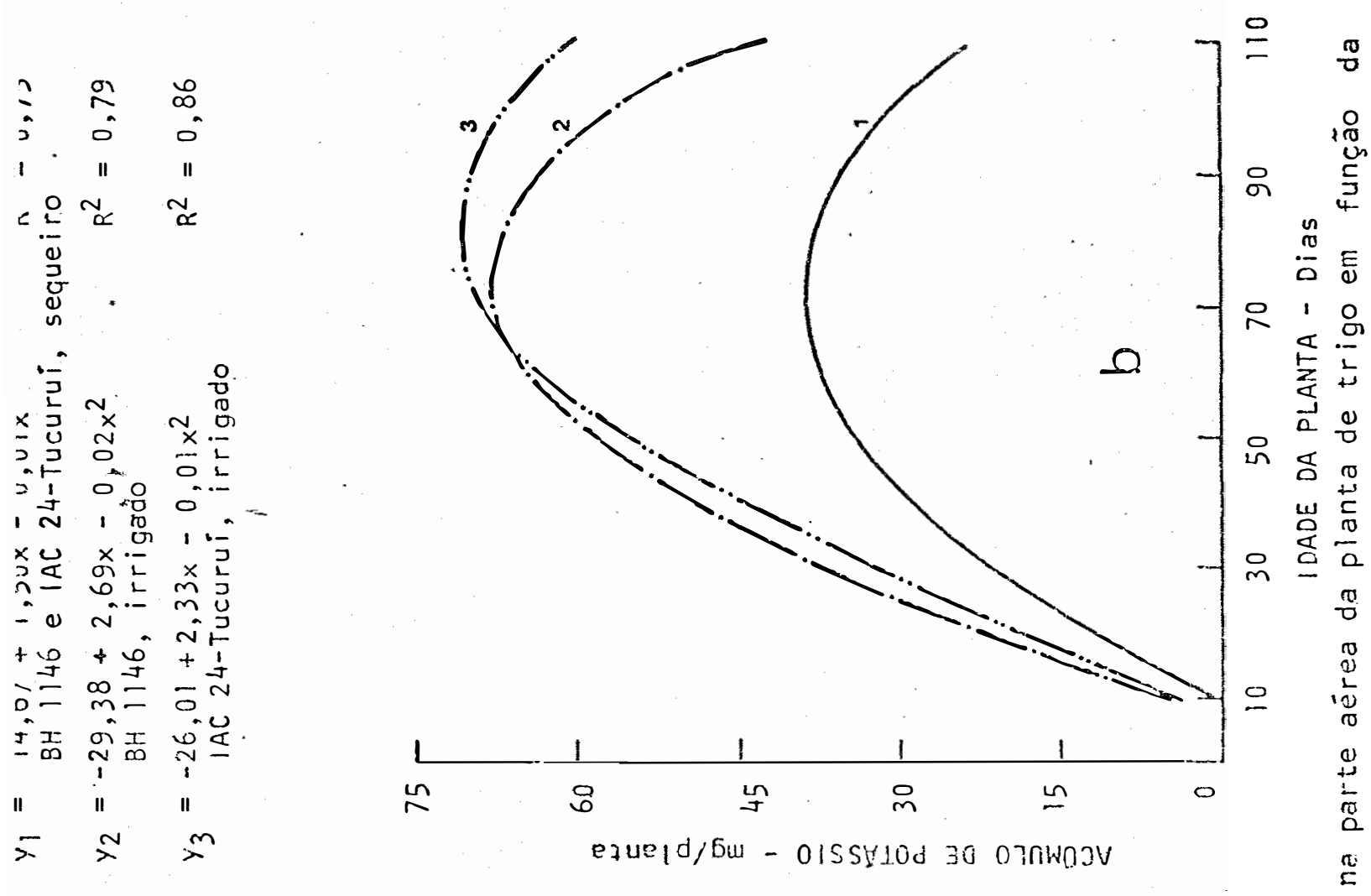

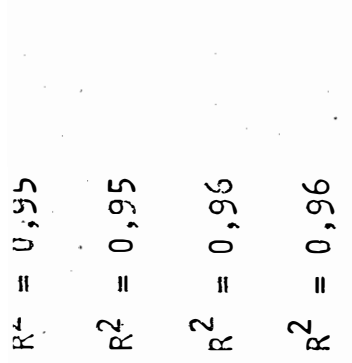
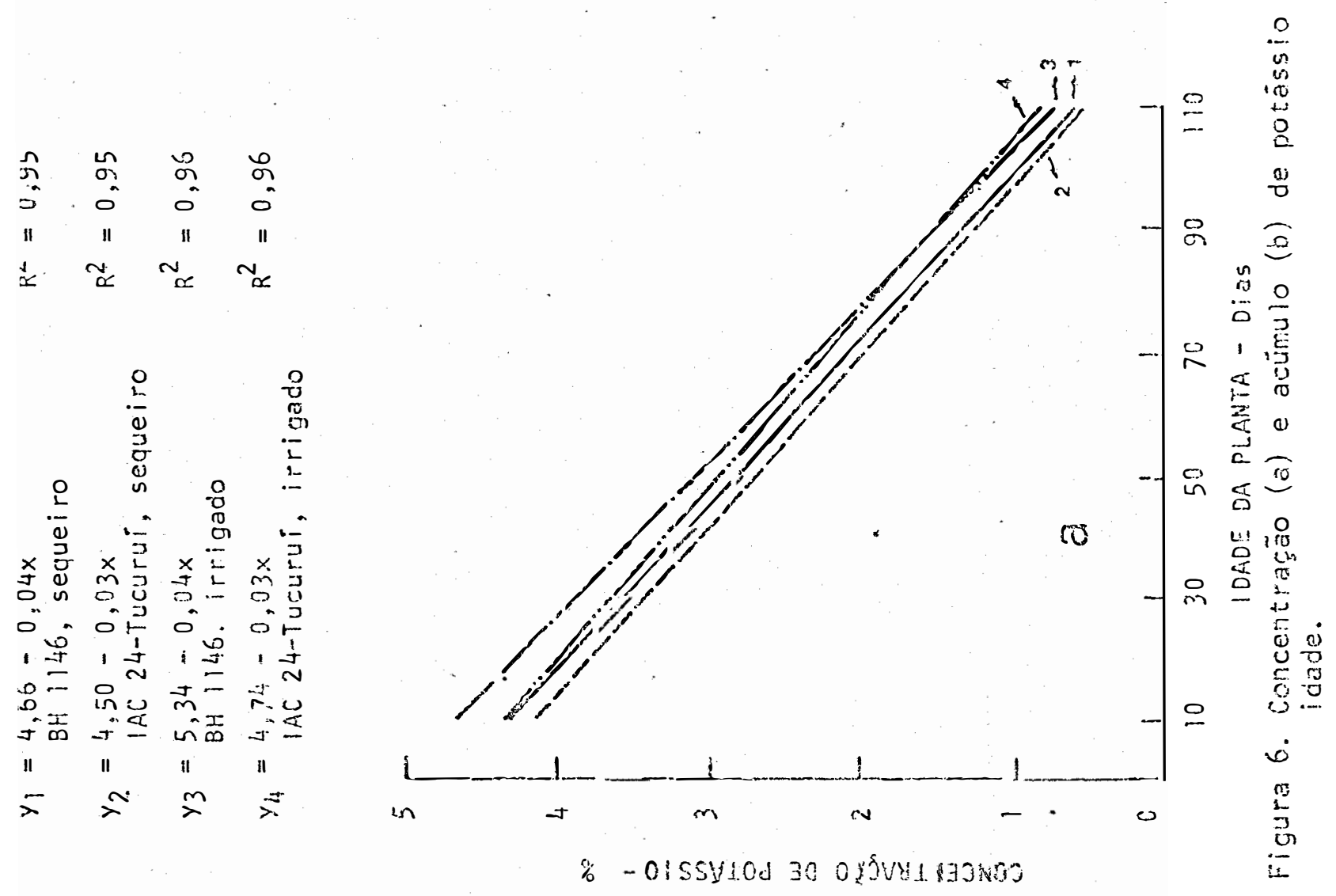
mente e quando irrigadas reduziram $45 \%$ e $22 \%$. As perdas elevadas deste nutriente devem ser consideradas em função da morte de folhas, as quais junto com o colmo são as principais acumuladoras de potássio. De acordó com ORPHANOS E KRENTOS (1980), os quais estudaram absorção de potássio em solos bem supridos deste nutriente, a concentração do mesmo nas folhas, colmos e grãos atingiu $3,09 \%, 1,33 \%$ e $0,50 \%$, respectivamente. - Em estudos de absorção de potássio por cereais de inverno, REMY (1938) mostrou que em trigo, àté o estádio da floração a planta absorve $81 \%$ do total absorvido até a maturação final. Na presente pesquisa o māximo ácúmulo ccorreu mais precocemente, o que pode ser explicado provavelmente pelas diferenças edafo-climáticas onde foram realizados os expe rimentos e também porque o autor acima utilizou cultivares de ciclo mais longo em sua pesquisa.

\subsubsection{CALC10}

Os dados referentes a concentração e acúnulo de cälcio nas duas cultires em duas disponitilidades de água podem ser observados na Figura 7 e Tabelas 4 e 5 .

Para as duas cultivares, independente da dispo nibilióade de ägua a máxima concentração de cálcio ocorreu no início do ciclo e a minima no estädio da flapą̃o, havendo a partir dá uma estabilização. A mäxima concentraçäo ao longo do ciclo ocorreu para a cultivar BH 1146 no regime de seque 
42 .
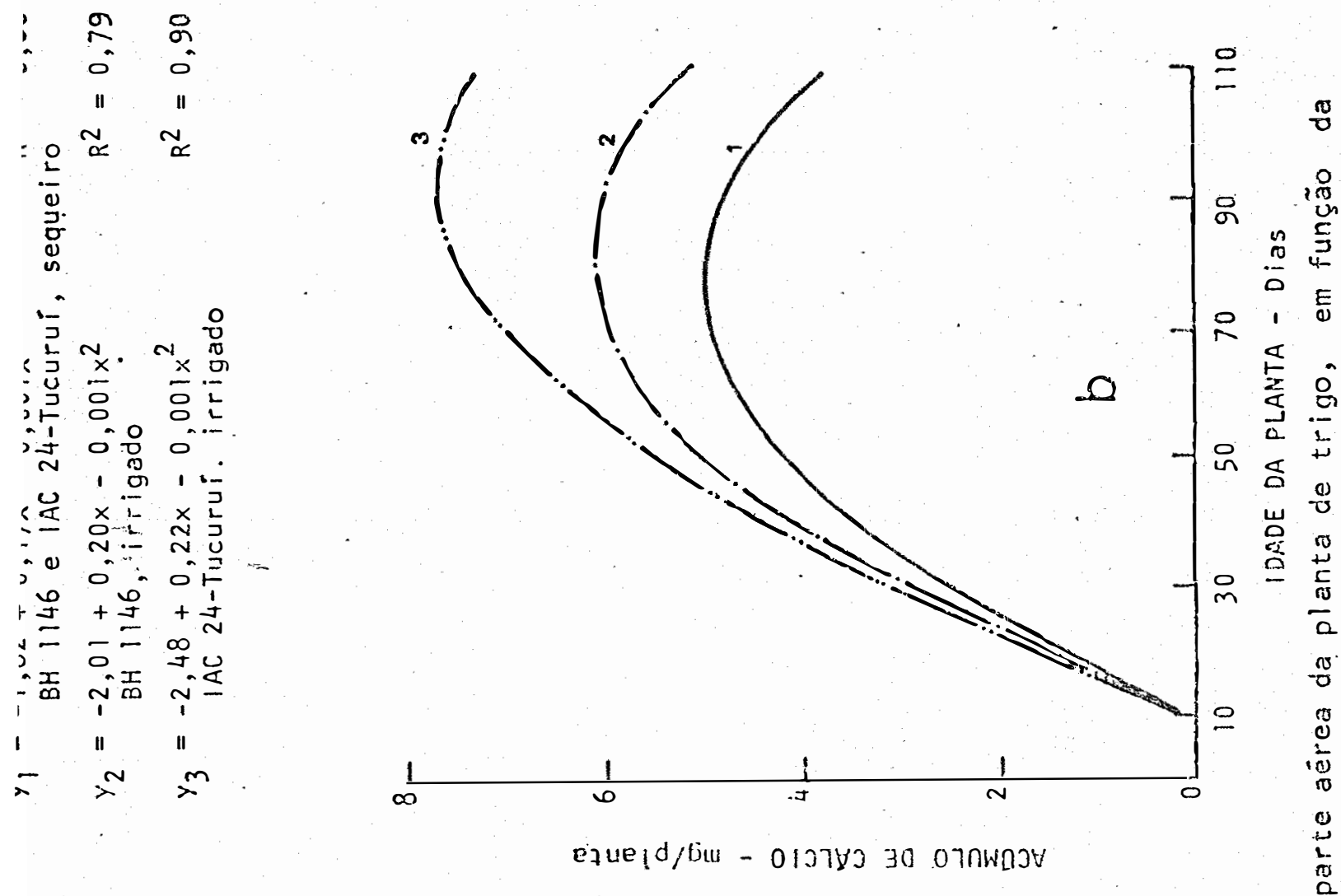

$\begin{array}{lll}2 & 0 & \text { n } \\ 2 & 0 & 0 \\ 1 & 11 & 11 \\ 1 & \sqrt{\alpha} & N_{\infty}\end{array}$

• \begin{tabular}{l}
0 \\
0 \\
0 \\
0 \\
\hdashline \\
\hdashline
\end{tabular}

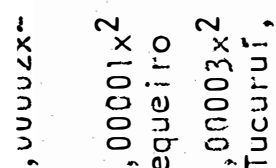

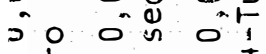

$+\frac{1}{x+a}$

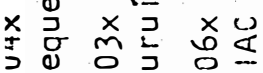

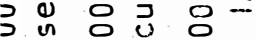

- of 0

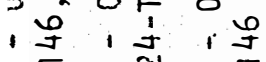

m= mo $N=$

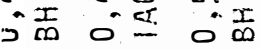

II II

$\therefore \approx x^{m}$

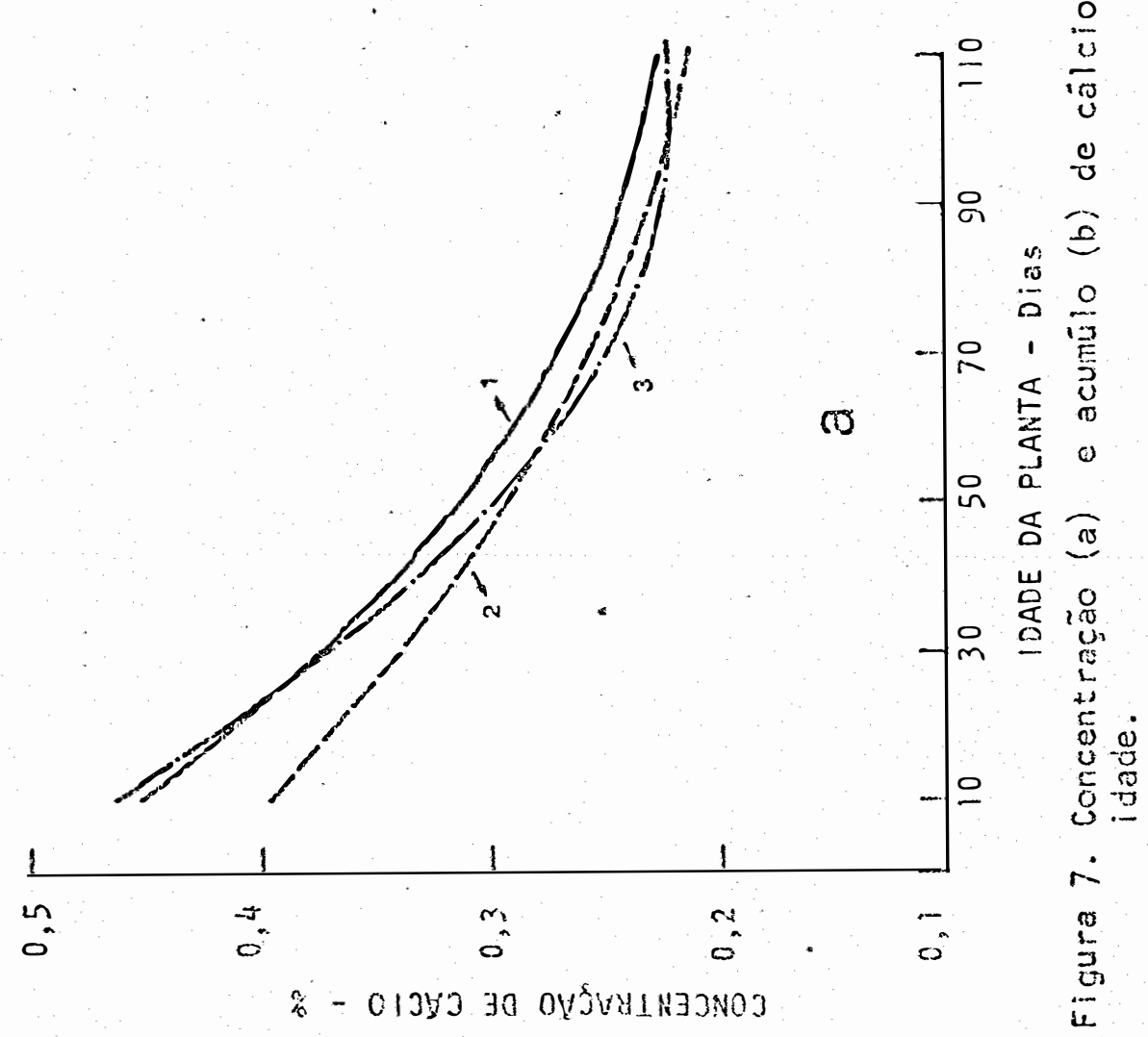


ro e sob irrigação as cultivares mostraram uma menor concentração, sendo que, não houve diferenças entre elas.

o menor acūmulo de cálcio ocorreu para as duas cultivares em regime de sequeiro as quais não mostraram di ferenças entre si. Nestas condições, aos 50 dias de idade a planta já havia acumulado o máximo deste nutriente, ocorrendo a partir daí um decréscimo. Com irrigação o mäximo acümulo na cultivar BH 1146 ocorreu no estádio de grão leitoso e na IAC 24-Tucuruí no estádio da floração.

No tratamento em que houve restrição de äqua, a partir do estädio de máximo acúmulo de cálcio até a maturação final houve uma perda deste nutriente de $40 \%$ e $24 \%$ para as cultivares BH 1146 e IAC 24-Tucurui, respectivamente. Para a primeira cultivar sob irrigação foram perdidos $29 \%$ e na segunda não houve perda, mostrando estabi i zação até o final do ciclo.

Estudando a absorção de nutrientes através das cultivares BH 1146 e IAS 3795 em ambiente controlado, GARGANrINI E BRANCO (1973), mostraram que as plantas atingiram a má $x$ ima concentração de cálcio aos 20 dias de lidade, e que a par tir dai manteve-se praticamente constante até o final do ciclo. No entanto, PAGE et alii (1977) a KARLEN E WHITNEY (1980) em estudos semelhantes móstram que a planta de trigo atingiu os mesmos teores no inicio do ciclo, sendo que a partir do apa recimento do pseudo-colmo iniciou uma queda na concentração, chegando a metade do teor no estädio de gräo mole. os resulta 
dos obtidos na presente pesquisa são comparáveis aos obtidos pelos dois últimos autores em que o máximo foi óbservado próximo ao emborrachamento. Além disso verifica-se que as variações de acūmulo de cälcio na planta são mais em função da prọ dução de matēria seca do que a concentráção do nutriente.

\subsubsection{MAGNESIO}

A concentração de magnēsio na parte aerea das duas cultivares cultivadas em sequeiro e da cultivar BH 1146 cultivada sob irrigação, decresceu sensivelmente do inicio do ciclo até a maturação final, sendo que na cultivar IAC $24-T \underline{u}$ curuí irrigada o maior decréscimo foi verificado aos 70 dias de ida de a partir daí houve estabilização (figura ba).

A Figurä 7 b e Tabelas 4 e 5 mostram que o acümulo de magnésio na parte aērea da planta, das duas cultivares semi irrigação e da BH 1146 cultivada com irrigação, foi crescente até o estädio de gräo leitoso, sendo que daí até a maturação final houve acentuada queda. A cultivar IAC $24-T u c \underline{u}$ ruí com irrigação mostra acúmulo crescente desde o início do perfilhamento até a maturação final.

Apesar do mäximo acúmulo de magnésio, nas duas

cultivares no sistema de sequeiro, ter cocorrido próximo ao fi nal do ciclo, estádio de grão leitoso, durante o emborracha mento as plantas jähaviam acumulado $84 \%$ e $75 \%$ de magnésio na cultivar BH 1146 e IAC 24-Tucurui, respecsivamente. Identicam 
45.

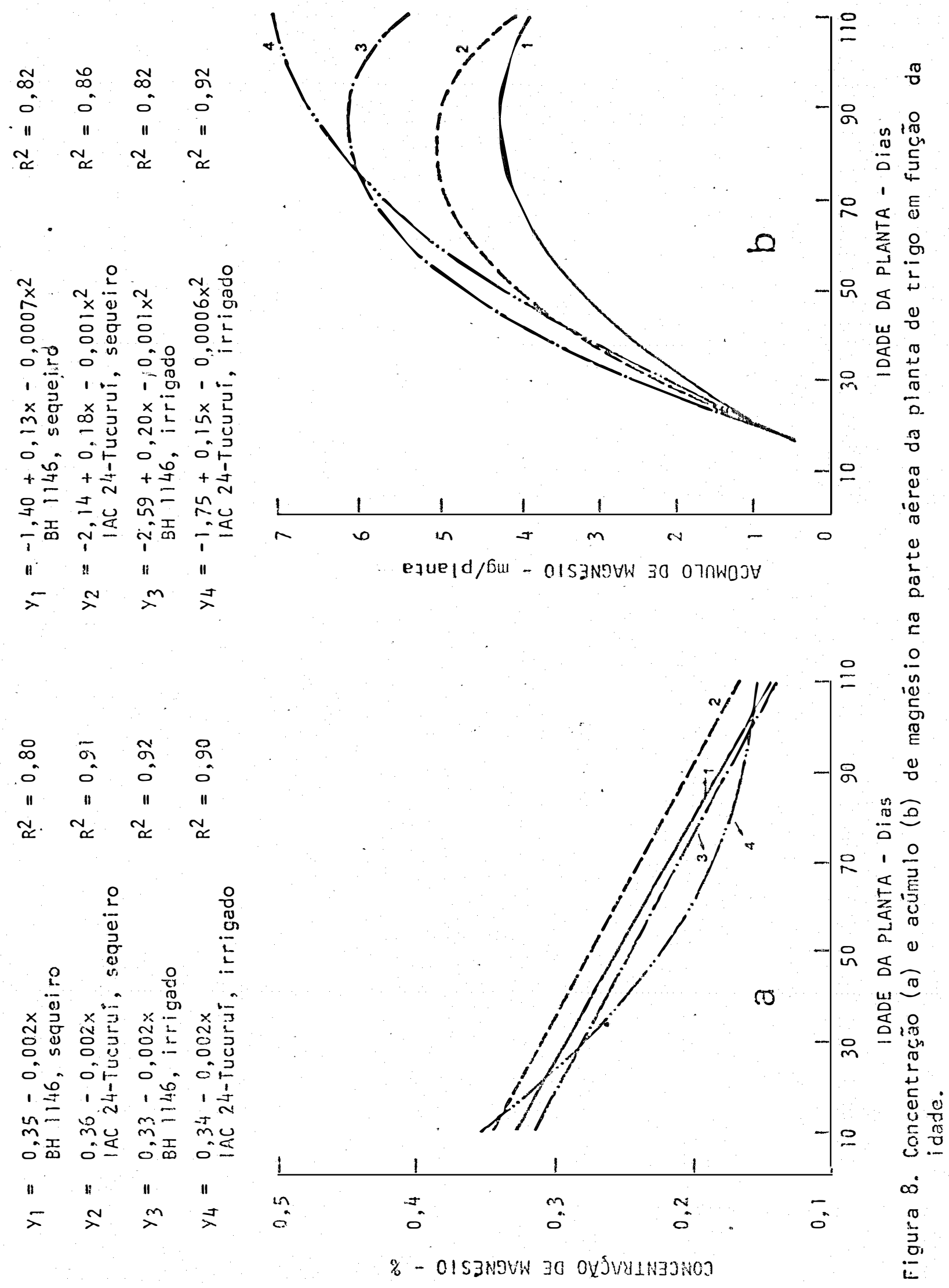


mente, até o emborrachamento, quando os cultivares receberam irrigação o acūmulo ocorrido foi de $63 \%$ para ambas.

As diferenças constatadas quanto a época de acú mulo máximo mostram principalmente, que em cultivos com irrigação o fornecimento do nutriente para a planta deve ser adequado durante todo o ciclo, principalmente para a cultivar IAC 24-Tucuruí.

Com a observação da Figura 3 b verifica-se nas duas disponibilidades de água, o menor acūmulo do nutrientena cultivar BHi 1146 e o maior na IAC 24-Tucuruí. Este comporta mento tambëm foi verificado com o nitrogênio, fösforo, potässio e cólcio.

GALIO et alii. (1972) estudando o comportamento de cultivares de trigo em solo ácido, mostram que en média os teores de Mg a lcançavan no mäximo $0,17 \%$ na parte aérea daplan ta, sendo que KARLEN \& WHITNEY (1980) encontraram valores pró ximos a este, no entanto, relatam haver constância no teor, desde o início ao final do ciclo. Estes resultados säodiscor dantes dos obtidos no presente trabalho, onde os valores foram superiores e a medida que a planta cresce há queda sensível na concentração. Com relação a efeito da irrigação, GAsSER \& THORBURN (1972) mostram que a irrigação decresce os teo res de $N$, Ca e lig na parte aérea da planta. Em trabalho com arroz utilizando três disponibilidades de água, Glub!CE Et alii (1983) mostram-que a irrigação por submersão continua proporcionou acümulo crescente de magnésio atē o final do ciclo. 


\subsubsection{ENXOFRE}

Para assimilação de enxofre atravēs das duas cultivares e disponibilidades de ägua, não foi possivel ajusliar modelos lógicos de regressão. No entanto, é possível verificar atravēs da Figura 9 e Tabelas 4 e 5 , uma tendência de concentração constante do nuṫriente nas quatra situações, até ó estádio de grão leitoso e queda no final do ciclo. No entan to, a cultivar IAC 24-Tucuruí, quando irrigada apresentou decréscimo do nutriente em sua composição a partir da floração.

No regime de sequeiro ocorreu o menor acūmuío do nutriente para as duas cultivares, quando comparado ao regime irrigado, sendo que as duas cultivares não mostraram diferenças entre si. No entanto, quando as cultivares foram irrigadas, a IAC 24 -Tucurui mostrou maior acumalo no final do ciclo do que a BH 1146.

As cultivares quando cultivadas em sequeiromos traram o máximio acümulo aos 90 dias de idade, sendo que óeste estádio até o final do ciclo â perda do nutriente em relação ao acümulo total foi de $28 \%$ na EH 1146 e $52 \%$ na IAC 24-Tucu ruí. Apresar da cultivar BH 1146 com irrigaça apresentar maior acúmulo de enxofre do que sem irrigaçäo, a perda a partir do estädio de grão leitoso até a maturą̧̃o foi de $41 \%$, sendo que a cultivar IAC 24-Tucuruí além de apresencar mäxima concentra. ção e acúmulo na floração aprescntou perda ât a maturaça do somente $8,5 \%$. 
48.

$\begin{array}{ccc}\text { N } & \text { ஸै } & \hat{\infty} \\ 0 & 0 & 0 \\ 11 & \| & \|\end{array}$

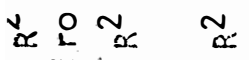
वे

ข

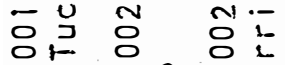

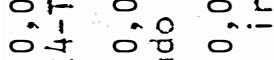

,, O,$\ldots$

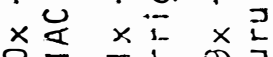

品 \pm m

o o a 0

$+\frac{0}{1}+\frac{1}{2}+\frac{1}{2}$

- $=\hat{0}=0$

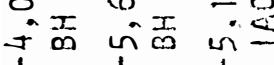

" 11

$\overline{2} x^{m}$

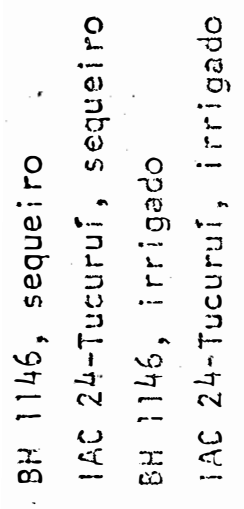

11 $\|$ "

- r m
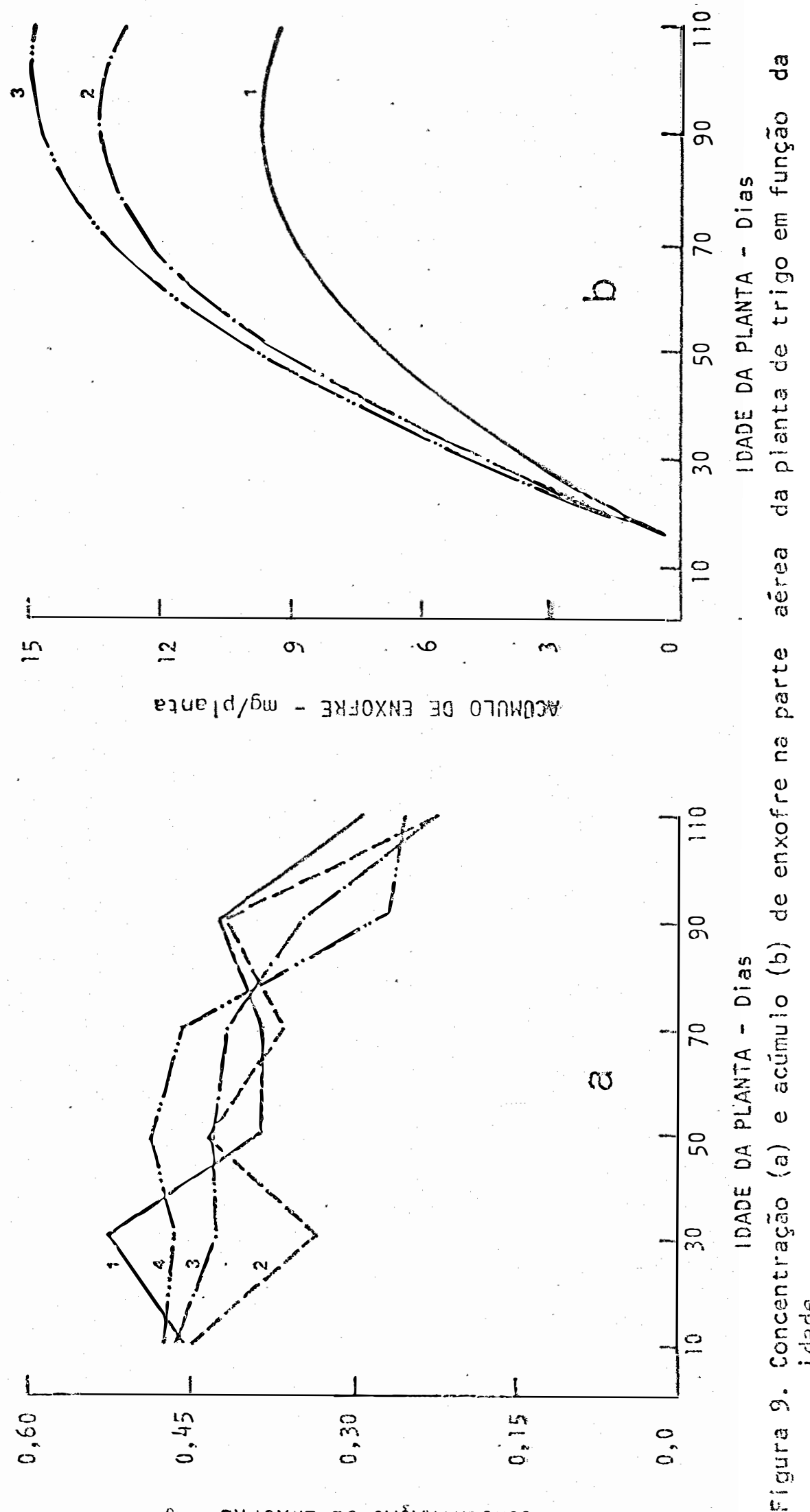

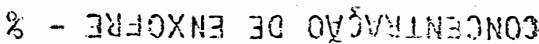

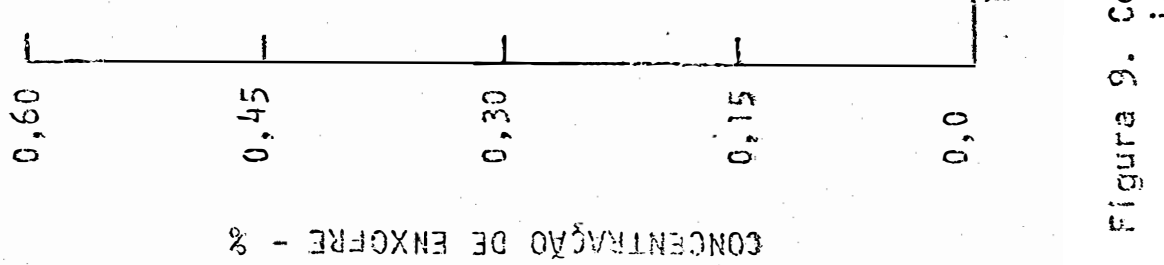


De acordo com KARLEN \& WHITNEY (1980) a concen tração de enxofre apresenta variações no decorrer do ciclo, com teores as vezes altos e baixos na faixa de $0,40 \%$ a $0,10 \%$, no início e final do ciclo, respectivamente. A concentrą̧ão final é concordante com RAMUSSEN et alii (1975) que em experimentos de adubação com enxofre obteve na parte aérea da plan ta, na maturação de $0,06 \%$ a $0,13 \%$. Sendo que na presente pesquisa, a mínima concentração verificada foi de $0,16 \%$ para am. bas as cultivares em sequeiro e $0,23 \%$ para á cuitivar BH1146 com irrigação. Estes resultados estão próximos aos obtidos por GAMA (1977a) que estudando absorção de enxofre em vasos através do trigo obteve teores médiós de $0,19 \%$ no final do ciclo.

\subsubsection{BORO}

o teor de boro nas plantas de trigo de duas cui tivares cultivadas em duas disponibilidades de ägua decresceu de início do ciclo áte o estädio da floração, sendo que a par tir dai houve aumento (Figura lo e Tabela 6). Até o estädio do elongamento, o comportamento de absorgão foi semelhante pá ra as duas cultivares, independente da disponibilidade de ägua, a partir daí foi verificada uma maior concentraçäo na cultivar Bit 1146 na condição de sequeiro quando comparada a IAC 24-Tucuruí. Este mesmo comportamento ocorreu no tratamen 

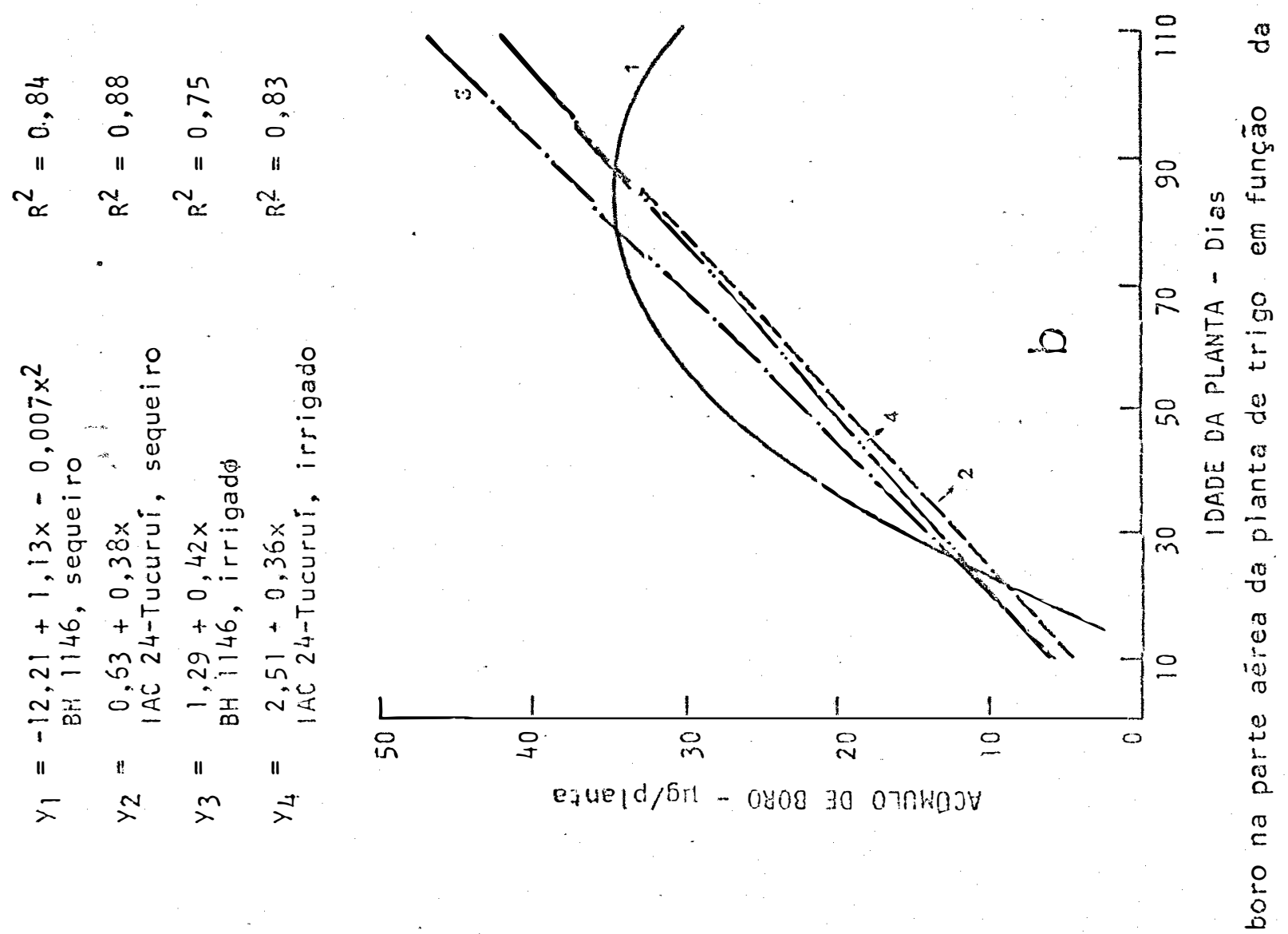

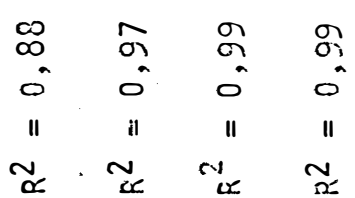

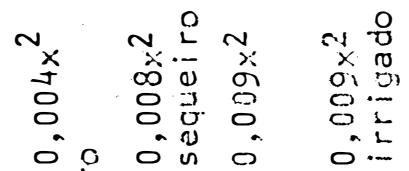

$+\frac{2}{0}+\cdots++\cdots$

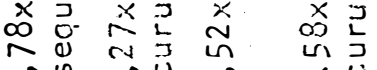

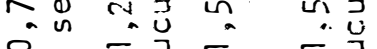

$1000,1,1$

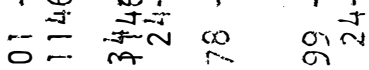

割现

II $\quad$ il il

$\bar{N} \stackrel{m}{n}$

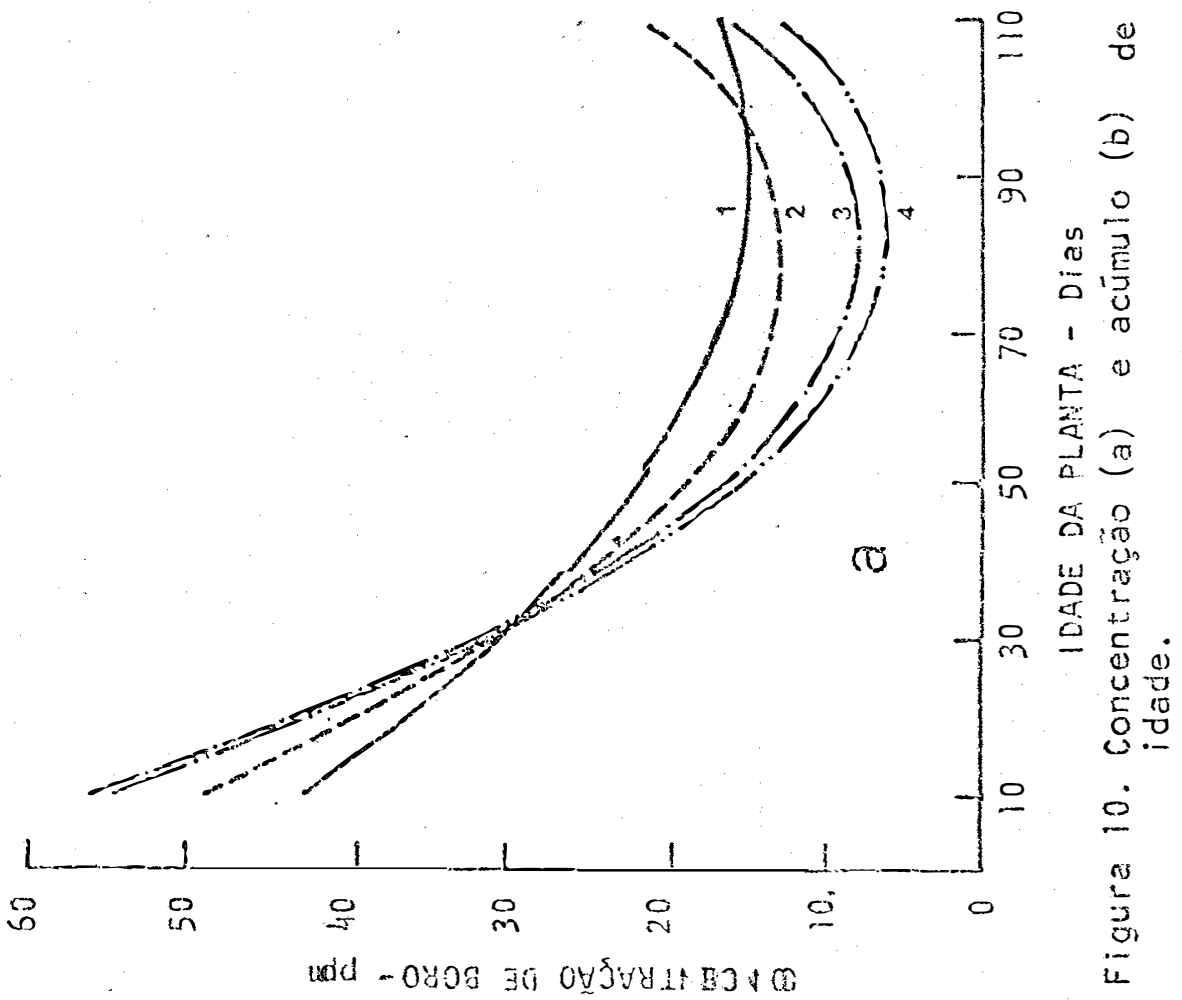


Tabela 6. Teor e acúmulo médio de micronutrientes em diversas idades, na parte aérea da planta de duas cultivares trigo cultivadas sob duas disponibilidades de água.

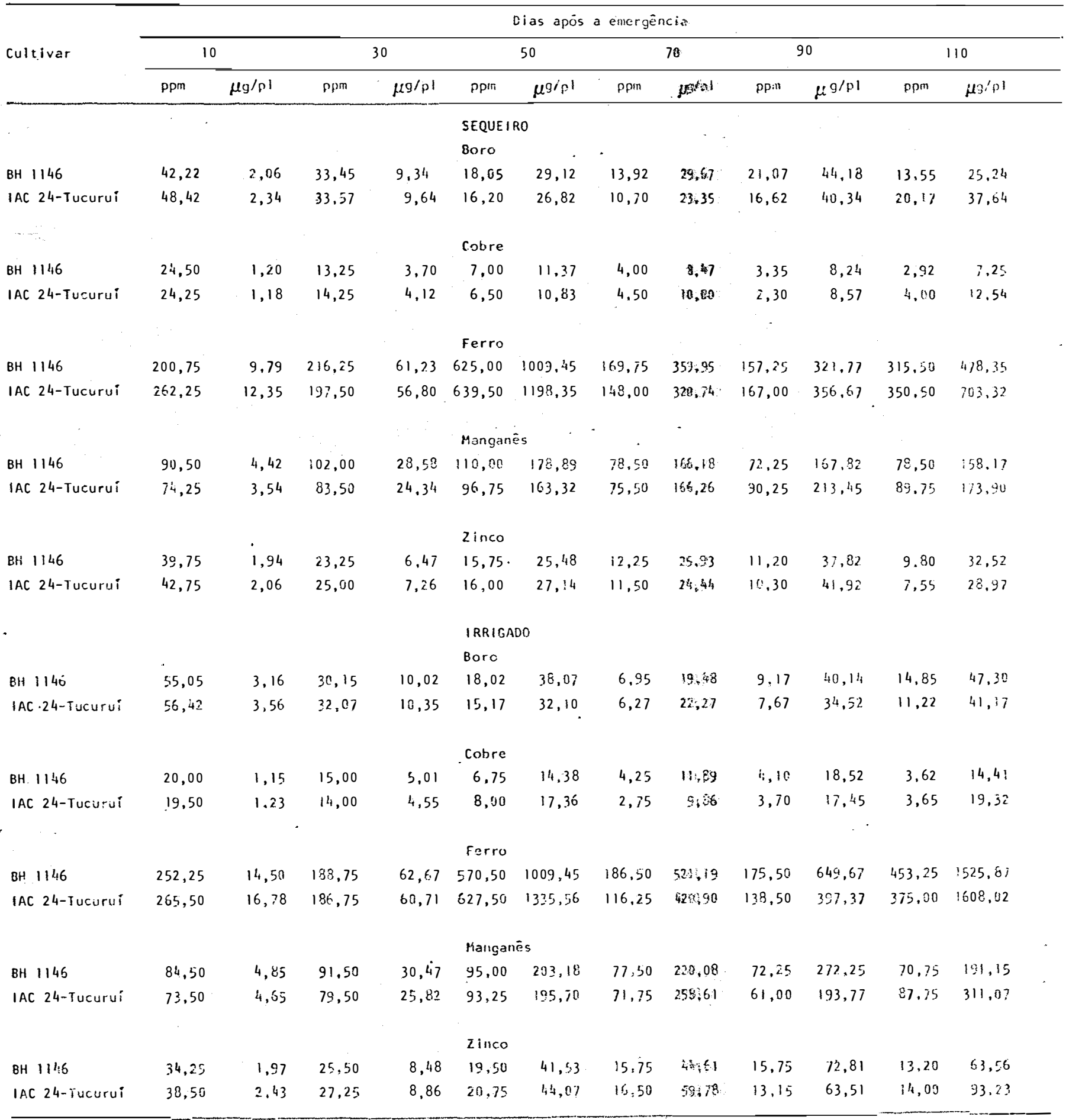


to com irrigação. Nas quatro situações estudadas, no final do ciclo as cultivares mostraram sensível aumento na concentração do nutriente.

A cultivar BH 1146 sem irrigação, mostrou desde os primeiros dias de vida até o estádio de grão leitoso, acūmulo crescente de boro, havendo queda quando aproximou - se da maturação final (Figura lob). Para a cultivar IAC 24-Tucu ruí, sem irrigação e as duas cultivares em tratamento irrigado foi verificado um comportamento linear crescente no acumulo do nucriente. Diferentemente da concentraçäo, quando as cultivares receberam irrigação, apresentaram maior acúmulo de boro e entre elas a IAC 24-Tucuruí mostrou maiores valores du rante todo o cicio. Na cultivar BH 1146 em sequeiro, foi verificada uma perda de $43 \%$ do nutriente, a partir do estádio de máximo acúmulo até a maturação final.

As plantas cultivadas em condições de deficiên cia hidrica de um modo geral apresentam maior concentração de boro em seus tecidos (LUCAS \& KNEZEK, 1972). Por outro lado, GULATI et alii (1980) mostram em experimentos testando doses do nutriente e niveis de irrigação, que a concentração na plan ta è mais influenciada pelo teor no solo do que pela disponibilidade de àgua. Na ültima pesquisa é mostrado que com irri gações mais frequentes há uma redução do teor na planta, o que o autor atribui a um maior movimento do nutriente no sentido decrescente. 
A anālise da concentração de cobre na parte aé rea da planta, mostra que não houve influência das cultivares, independente da disponibilidade de água (Figura lla), sendo que no inficio do ciclo ambas as cultivares apresentaram maior teor em condições de sequeiro e no final do ciclo isto ocorreu com a irrigação. A partir dó estádio de grão leitoso hou ve tendência de estabilização na concentração para as duas disponibilidades de água. Esses resultados são concordantes aos obtidos por FURLANI et ali (1977) que estudando três cu! tivares de arroz cam irrigação por submersão contínua, compro varam não haver diferenças ențre elas quanto a assimilação de cobre.

No tratamento com restrição hídrica, foi detec tado o menor acúmulo do nutriente, sendo que a cultivar BH 1146 acumulou menor quantidade e apresentou decrescimo no final do ciclo de aproximadamente $12 \%$ e a IAC 24-Tucurui acumulou maior quantidade, mostrando tendência a estabilizas̆o desde o estádio do emborrachamento até a maturação finẩ. Já com íriga ção a cultivar IAC 24-Tucuruí mostrou aćmblo crescente, a tin gindo c máximo de aproximadamente 19 plj/plamta no final do ci clo'e a outra cultivar cresceu até a idade de 90 dias, decres cendo posteriormente para $73 \%$ da concentraço máxima (figura 11 e Tabela 6). 


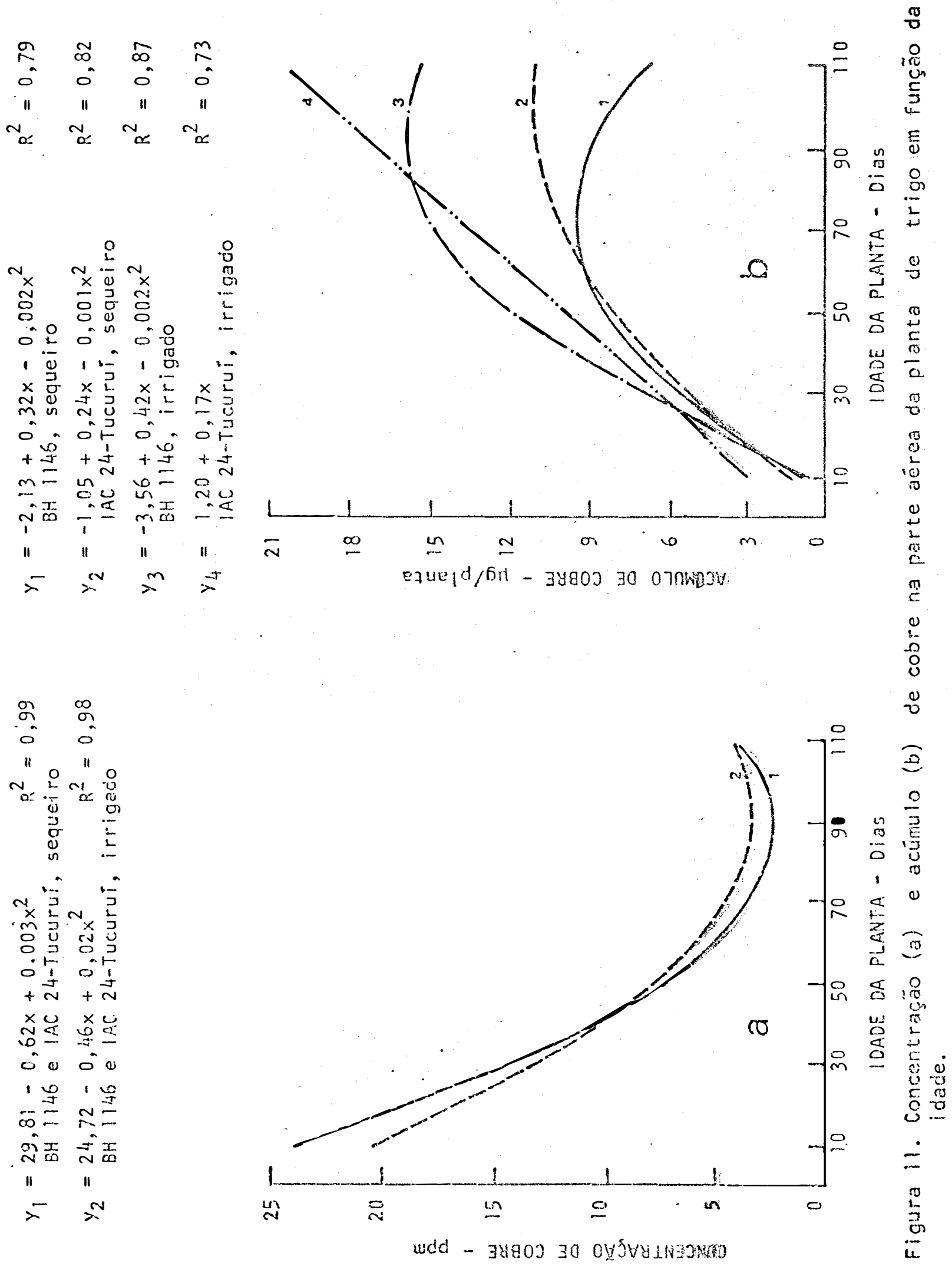


CHAUDHRY E LONERAGAN (1970) estudando o acúmu10 de cobre em três estädios, através da cultivar de trigo de ciclo longo "Gabo", relatam que no início do ciclo o acúmulo do nutriente por planta atingiu $1,21 \mu \mathrm{g}$ e aos 61 dias acumulou $3,7 \mathrm{lg}$. Os valores encontrados pelos autores são inferiores àqueles obtidos neste trabalho, tanto para as condi-. çöes àe sequeiro como irrigado. No entanto, resultados obtidos por BRAR \& SEKHON (1978) em solo de região de clima seco da India, mostram cocentrações na planta aos 75 dias de ida de em torno de 6 ppm, sendo que este valor é superior aos obtidos nesta pesquisa, mesmo com o uso da irrigação.

\subsubsection{FERRO}

A absorção e acümulo de ferro nas plantas de trigo das duas cultivares, estudadas em duas disponibilidades de água, ocorreu com variações ao longo do ciclo, sendo que não foi possível estabelecer um modelo lógico de regressão pá ra estudo (Figura 12). Tanto no regime de sequeiro como no irrigado, as cultivares näo apresentaram diferenças quanto a absorção do nutriente. Já o àcúmulo em sequeiro, foi superior zo longo do ciclo na cultivar iAC 24-Tucurui e sob irigạ̧ão as cultivares não apresentaram diferenças (Figura 12b). A concentração de ferro veri ficada por ocasião da floração, na parte aérea das cultivares "Siete Cerros", "Alondra $5-46 " 1$ e IAC 5-Maringá en três anos de cultivo obtados por batagLIA ét 
56.
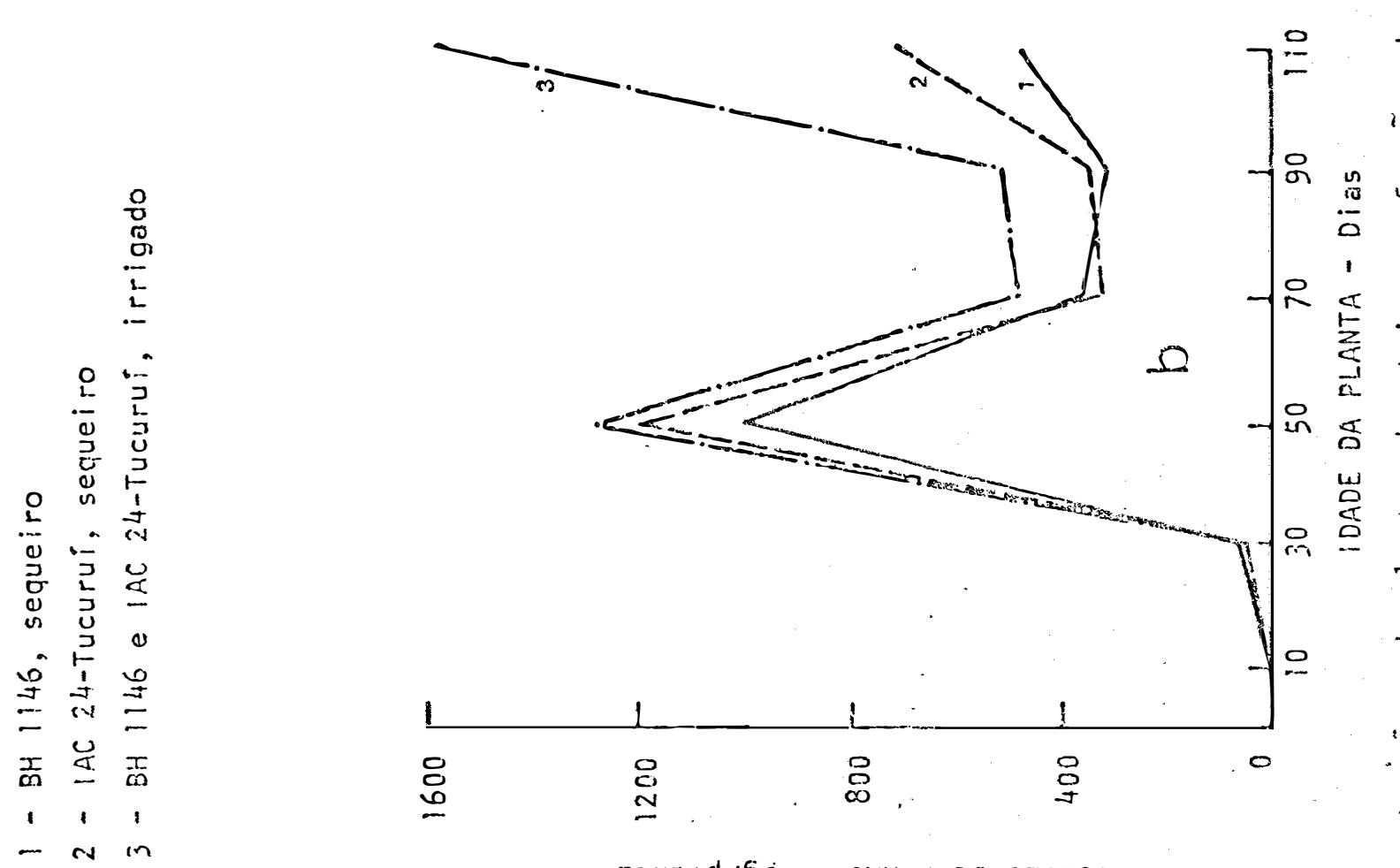

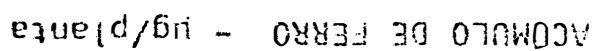
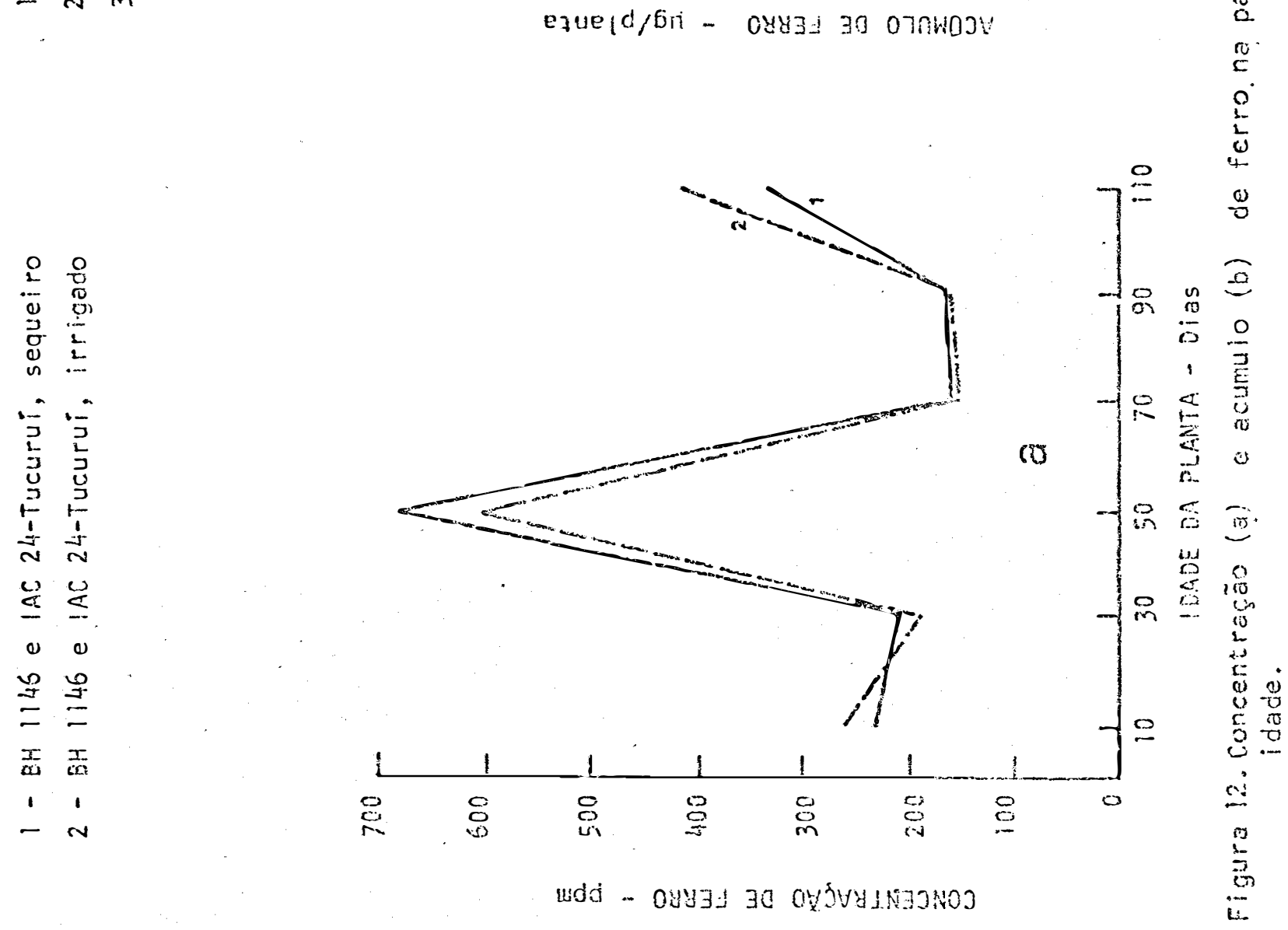
ali (1985) estão bastante próximas das obtidas ro presente trabalho. No entanto, BRAR \& SEKHON (1978) obtiveram em plan tas cultivadas em solo de baixo teor em ferro o máximo de 160 ppm na parte aérea da planta.

A Figura 12 a e Tabela 6 mostran em duas ëpocas de amostragem, 50 e 110 dias, concentrações na planta superiores àquelas consideradas normais quando comparadas a literatura. Os valores considerados anormais fonam obtidos de coletas realizadas após periodos de intensas chuvas, conforme mostra a Figura 1. GIORDANO E MORTVEDT (1972), GALRAO alii (1978) e FAGERIA (1934) mostram que a disponibilidado de ferro para a planta é consequéncia do estado oxirredutor do solo, concluindo assim que a redução do solo, decorrente do aumento da umidade do solo aumentava a disponibilidade do nutriente para a planta. Além da maior disponibilidade de ferro no estádio de emborrachamento é nesta idade que a planta apresenta maior massa foliar e como. as folhas juntamente com os colmos são os maiores armazenadores de nutriente, hä unia grande contribuição destas partes no aumento do teor total na planta inteira.

\subsubsection{MANGANES}

Através da añ̄lise da Figura l3a e Tabelá, verifica-se que a absorf̧ão de manganés pelas plantas das duas cultivares, em duas disponibilidades de agua ocorreucom va- 


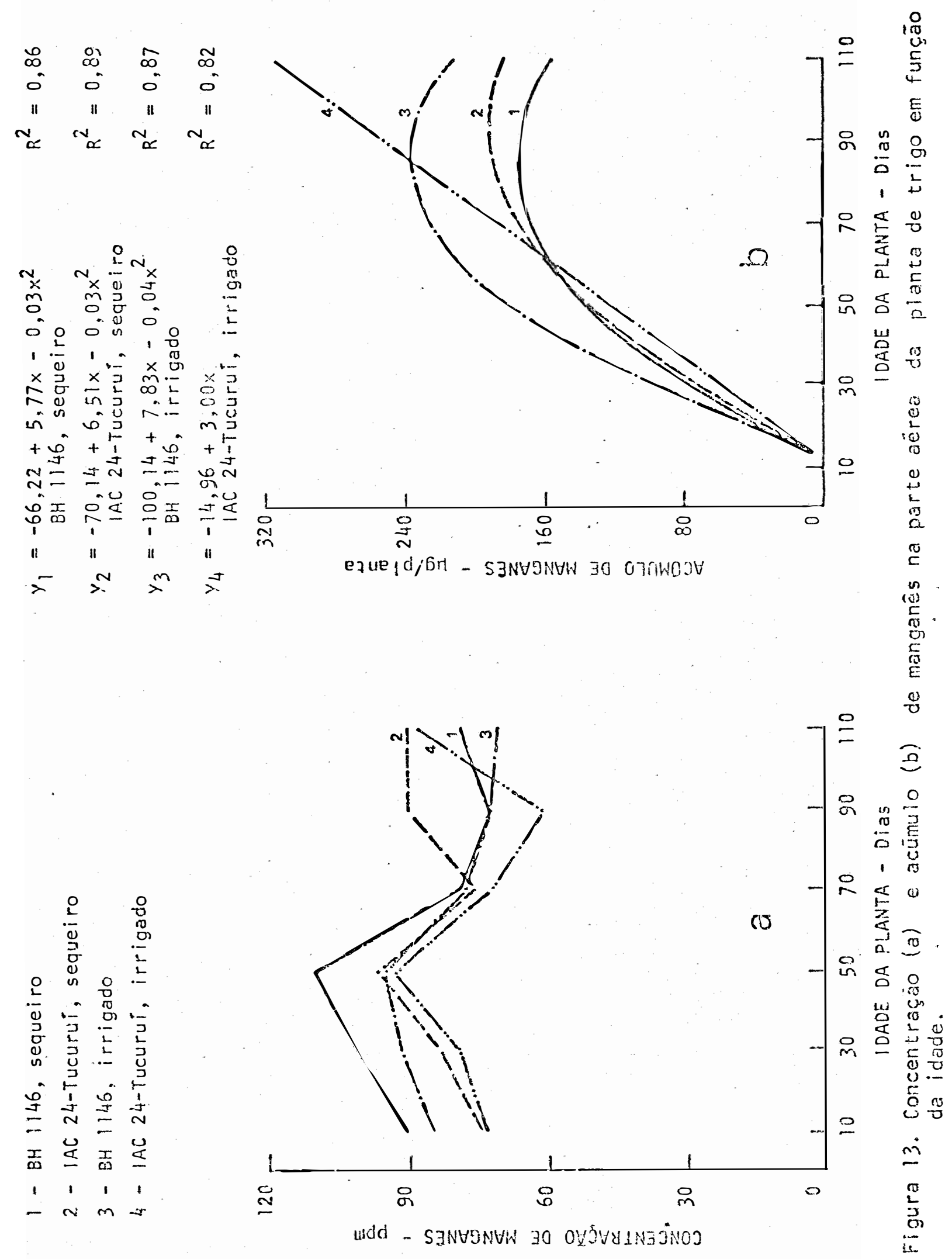


riações ao longo do ciclo, não sendo possível estabelecer modelo lögico de regressão. A ocorrência de máxima absorção pe la planta aos 50 e 110 dias de idade tern fundamento no que foi relatado para o ferro, pois estas idades de coleta foram precedidas de períodos chuvosos, colocando maior quantidade de manganês disponível na solução. FAGER!A (1984) relata que a concentração do nutriente na solução do solo aumenta com a inundação por favorecer a redução das formas complexas de Mn a $\mathrm{Mn}^{+2}$, que ë predominantemente absorvido pelas plantas. Apesar da variação ocorrida, a concentração nas duas cultivares em sequeiro, em determinados estädios foram superiores aos tratamentos com irrigação, destacando-se a cultivar $84 \quad 1146$ do início do perfilhamento a floração e la.c 24-Tucuruí da fio ração atë a maturação. A maior absorção ocorrida em sequeiro é concordarte com resultados obtidos com arroz por GlUDiCE et alii (1983) os quais trabalhando com três diférentes dis ponibilidades de àgua mostraram que com maior disponibilida de houve maior absorfäo do nutriente.

Os ieores de manganês detectados por alguns au tores estäo acima dos obtidos nesta pesquisa. GALlo et ali i (1972) e BRAR \& SEKHON (1978) obtiveram concentraçöes entre 157 e 174 ppm. No entanto, BATAGLIA et alii (i985) trabalhan do em solos brasileiros no Estado de São paulo mostram valores médios entre 60 e $90 \mathrm{ppm}$, sendo que em quatro anos de estudo, somente no primeiro obtiveram diferenças entre cultivares. 
o acūmulo de manganès nas duas cultivares, no regime de sequeiro atingiu o mäximo aos 50 dias de idade, sendo que a IAC 24-Tucuruí apresentou maior vaior, e a partir desta idade ambas mostraram estabilização. Em regime de irrigação ocorreu o mäximo acūmulo, sendo que na cultivar BH1146 cresceu até a idade de 90 dias, decrescencio posteriormen te e a IAC 24-Tucuruí apresentou crescimento linear do inicio áté o final do ciclo (Figura 13b).

\subsubsection{ZINCO}

A concentração de zinco na parte aérea das plantas das duas cultivares, mostrou diferenço entre cuitivares mesmo quando cultivadas em à iferentes disponibilidades de água (Figura 14). No início do ciclo as cultivares apresentaram a máxima concentração, com teores entre 34 e 43 ppm, sen do que a cultivar IAC 24-Tucuruí sem irrigação apresentou maior valor e menor a BH 1146 com irrigação. Ambas as cultivares, independente da disponibilidade de água apresentaram decrésci mo nos teores do nutriente do início do ciclo até o estä́dio da floração, havendo a partir daí tendência a estabilizaçäo com valores nas faixas de 8-12 ppm e 13-16 ppm para os regimes de sequeiro e irrigado, respectivamente. Os teores de zinco aicançados através desta pesquisa comparados aos obtidos por CARROLL \& LONERAGAN (1968) são considerados adequados, pois os autores verificaram que em umáa solução nutritiva de $0,01 \mu M$, 

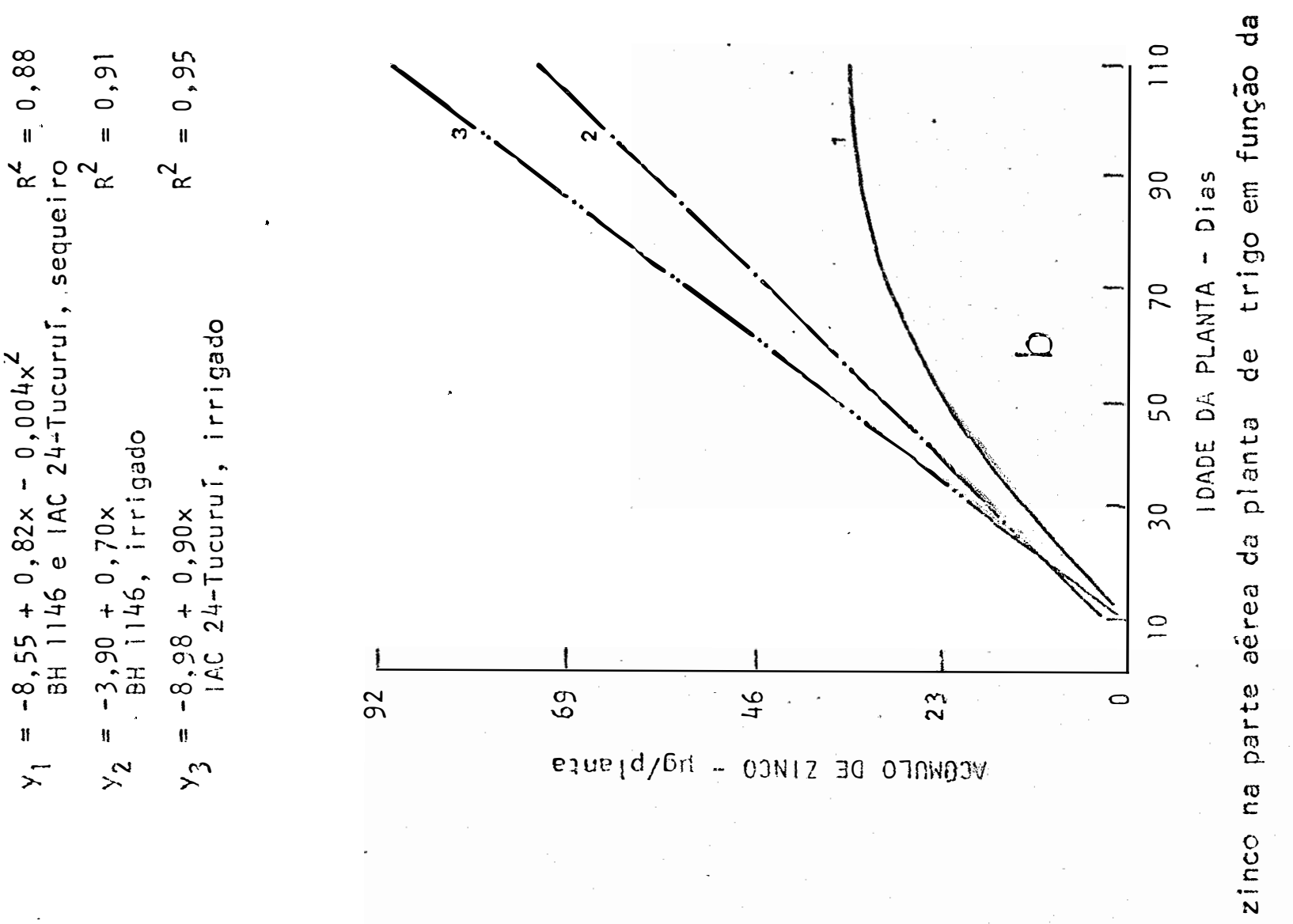

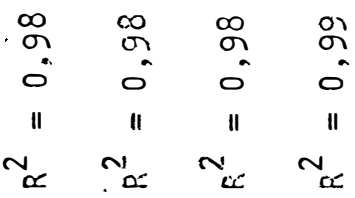
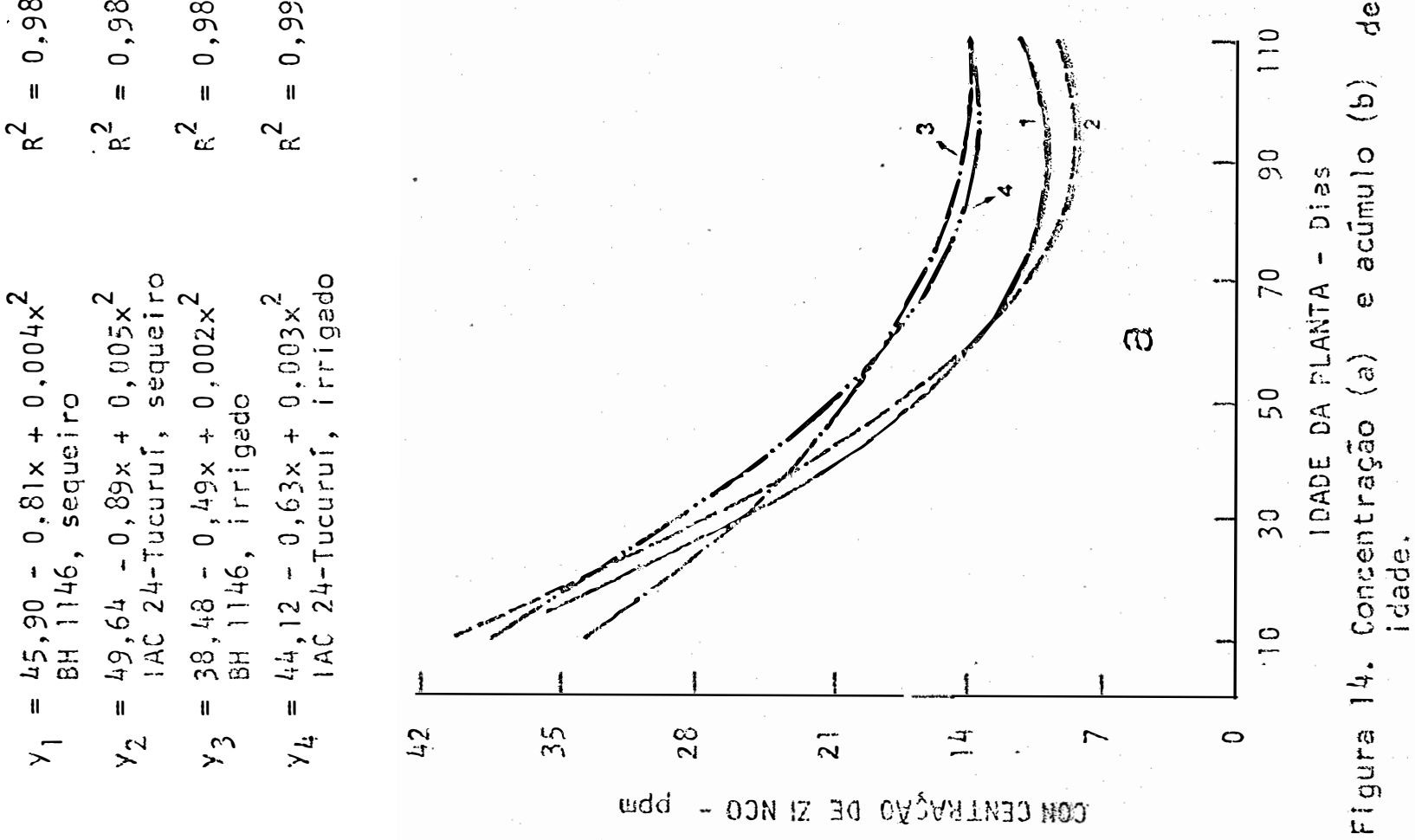
que produzia o máximo peso fresco em uma planta de trigo, o teor na parte aérea aos 46 dias de idade era de 29 ppm. Em trabalho semelhante em solo de aluvião com 0,37 a 0,45 ppm de $2 n$, SINGH et alii (1980) relatam que a planta. de trigo acumuia no tecido da parte aérea aos 50 dias de idade, aproximadamente $17 \mathrm{ppm}$ de $2 \mathrm{n}$, sendo que a concentração que garante $90 \%$ da produção máxima è 24,5 p̀m.

$\rightarrow \quad$ BATAgLIA et ali $\quad$ (1985) estudando a concentra ção de Zn em três cultivares de trigo obtiveram em três anos de estudo, diferença entre cultivares, sendo que os maiores teores foram encontrados na IAC 5-Maringá brasil leira, com valores entre 12,2 e 18,4 ppm e as mexicanas "Siete Cerros"e"Alon dra $5-46^{\prime \prime}$ com valores entre 8,9 e 17,1 ppm.

0 acúmulo do nutriente na parte aérea das duas cultivares em condições de sequeiro não mostrou diferenças, ocorrendo crescimento do início do ciclo até os 50 dias de idade. Já em condições de irrigação, o acümulo foi crescente do início do ciclo até a maturação final, mostrando que a cultivar IAC 24-Tucuruí acumula maior quantidade, sendo que na BH 1146 o maior acúmulo verificado foi de $73 \mu \mathrm{g} / \mathrm{pl}$ anta e na IAC 24-Tucuruí, 93 jig/planra (Tabela 6). As quantidades acumuladas pelas cultivares em regime de sequeiro, aos 50 dias, säo concordantes aos apresentados por CHADHRY \& LONERAGAN (1970) na mesma idade. 
63.

\title{
4.3. ACÚMULO DE MATÉRIA SECA E NUTRIENTES NAS PARTES DA PLANTA
}

\author{
4.3.1. MATERIA SECA
}

os pesos médios de matēria seca contidos nas partes da planta, das duas cultivares e disponibilidades de ägua năs idades de 90 e 110 dias estão apresentados na Tabela 7. Na cultivar BH 1146 o acümulo de matéria seca nas duas ida des, aumentou em todas as partes estudadas com a disponibilidade de àgua, com excessão das folhas bandeira que aos 110 dias de idade permaneceram inalteradas. Com a cultivar IAC 24-TuCu ruí ocorreu de forma semelhante, somente a produção de materia seca nos gräos na iciade de 90 dias permaneceu inalterada com a mudança de disponibiliáade de ägua. Com relação a idade da planta, ambas as cultivares independente da disponibiiidade de àgua, não mostraram alteraşăo na produçäo de matêria se ca nas partes estudadas, dos 90 para os 110 dias de idade, com excessão das folhas bandeira que com 90 dias produziu maior quantidade e os grãos com ilo dias na cultivar IAC 24-Tucuruí em regime irrigado.

$$
\text { A maior produção de matéria seca através dos }
$$

grãos da cuitivar IAC 24-Tucuruí com irrigação mostra a capacidade desta cultivar com disponibilidade adequada de água em permanecer o enchimento de gräos até o final do ciclo. 
Tabela 7. Teores de matēria seca em g/planta contidos nas partes da planta de duas cultivares de trigo estudadas em duas disponibilidades de àgua.

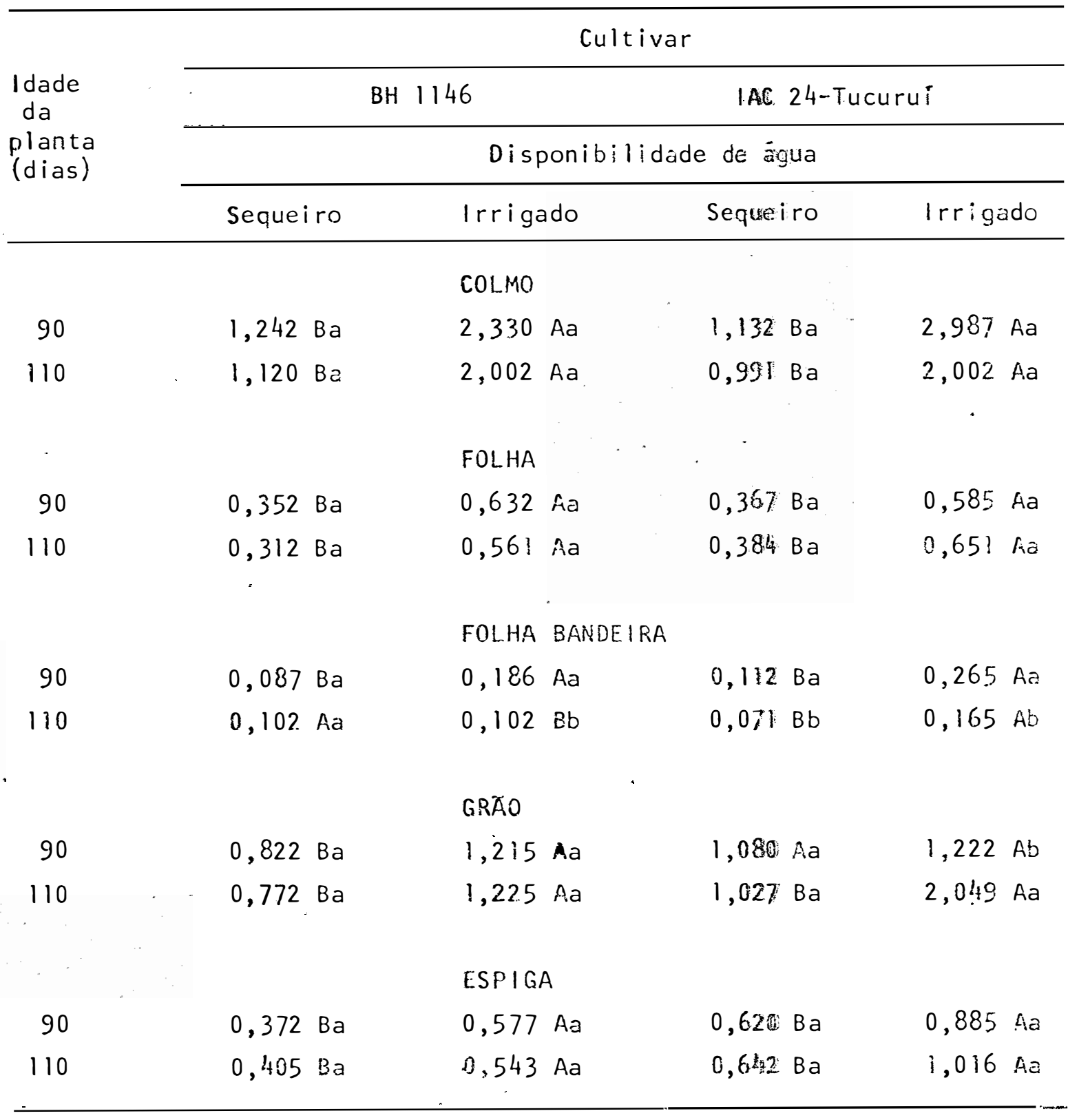

- Para cada cultivar, dentro de cada linha as médias seguidas da mesma le tra maiúscula e dentro de cacia coluna para cada parte da planta, as mëdias de idade seguidas da mesma letra minüscula, não diferem significativamente entre si, pelo teste de Tukey a nivel de $5 \%$ de probabilidade. 
65.

BOATWRIGHT E HASS (1961) relatam que o decrés cimo no peso de matéria seca das partes da planta a partir da formação dos grãos é evidente, visto a translocação de nutrientes a açūcares para este ültimo e mesmo o retorno de alguns nutrientes para as raízes e solo. Os autores evidenciam que - peso da matéria seca dos grãos tem acréscimo acentuado ápar tir da emissão da espiga até a maturação. GARGANTIN E BLANCO (1973) estudando em ambiente controíado a culivivar BH 1146 re latam que o acūmulo máximo de matéria seca na espiga ocorreu aos 100 dias, havendo a partir daí um decréscimo.

\subsubsection{NITROGENIO}

0 peso médio em $\mathrm{mg}^{\prime}$ de nitrogênio acumulado e a sua concentração nas partes da planta, nas idades de 90 e 110 dias, para as duas cultivares e disponibiliades de ầua estão apresentados na Tabela 8. A maior quantidade de nitrogênio acumulado nas partes da planta de trigo da cultivar BH 1146 ocorreu com o regime de irrigação. Para os colmos e foThas bandeira, o maior acümulo de nitrogênio ocorreu no fina! do ciclo, nas duas disponibilidades de ägua, nos gräos e espigas não houve diferenças de acümulo com idade, sendo que as folnas desta cultivar em condições de sequeiro não alterarám o conteúdo de nitrogênio com idade ao passo que com irrigação houve maior acümulo aos 90 dias. miligrama 
86.

Tabela 8. Teores médios de nitrogênio, contidos nas partes da planta de duas cultivares de trigo estudadas em duas disponibilidades de ägua.

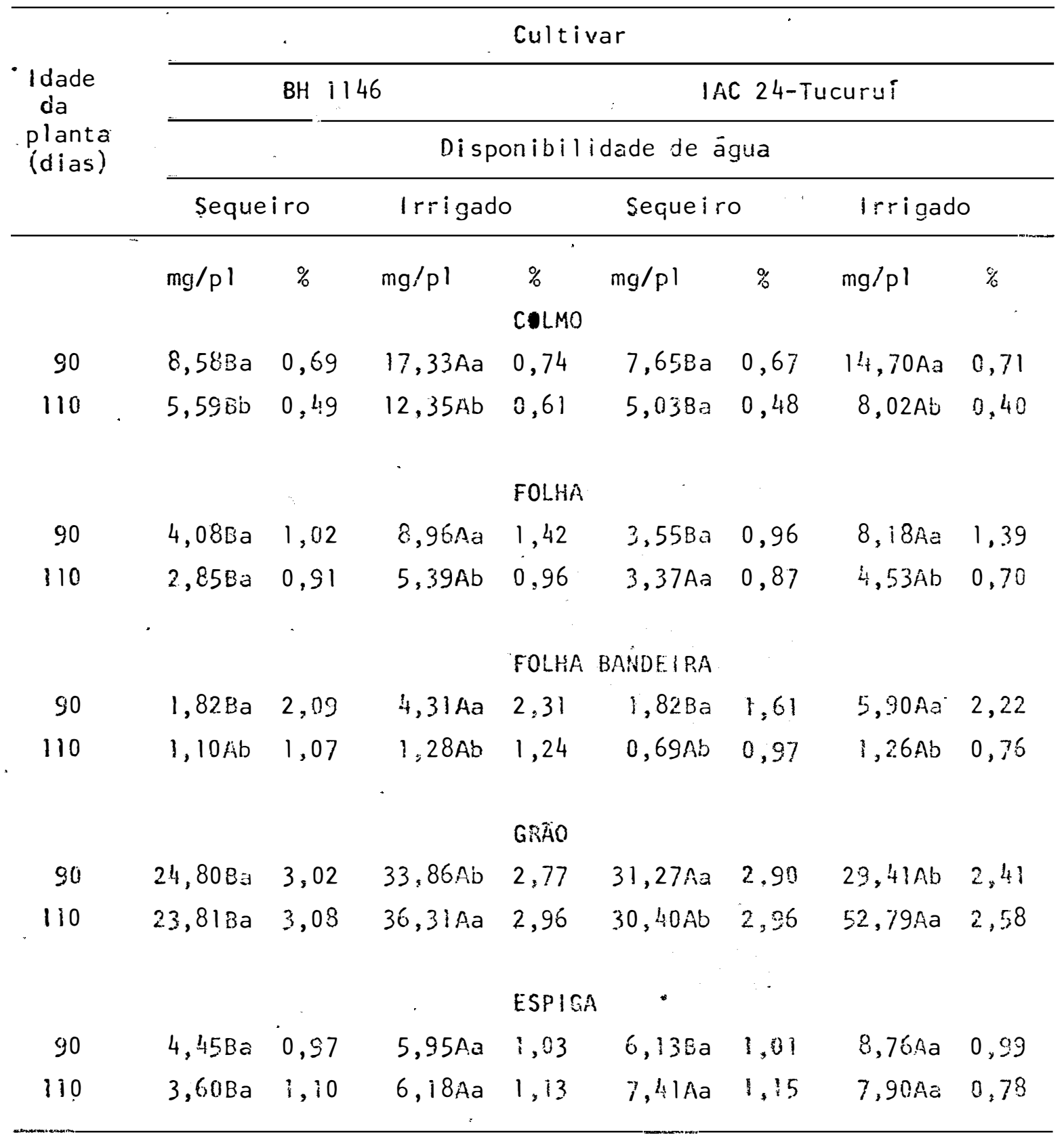

- Para cada cultivar, dentro de cada linha, as médias seguidas da mesma letra, maiuscula e dentro de cada coluna parc cada parte da planta, as médias de idade seguidas da mesma ietra minúscula räo diferen signitica tivamente entre si,pelo teste de Tukey conival de $5 \%$ de probabilidade. 
A cultivar IAC 24-Tucurui com 90 dias de idade, nas cinco partes estudadas, apresentou maior conteúdo de nitrogênio em condições de irrigação, com excessão dos grãos que não diferiu nas duas disponibilidades de ägua. Já no final do ciclo, aos 110 dias de idade, as folhas, folhas bande ra e espigas, não mostraram diferenças quanto ao acúmulo deste nutriente, comparando-se as duas disponitsilidades de ägua, sendo que os colmos e grãos apresentaram maior conteüdo quando as plantas receberam irrigação.

Na cultivar BH 1146, nos colmos e folhas bandeira o acumulo do nutrientes decresceu com idade nas duas dis ponibilidades de água, nos grãos e espigas não houve diferença para as idades; independente da disponibilidade de ägua, sendo que com irrigação houve maior acúnulo de nitrogênio aos 90 dias, não mostrando diferença do regime de sequeiro. A cultivar IAC 24-Tucuruí em regime de sequeiro não modificou - acúmulo do nutiriente dos 90 aos 110 dias de idade ros seas ärgäos, com excessão das folhas bandeira que aos 90 dias apre sentou niaior conteüdo e com irrigação, os coimos, follias e fo Ihas bandeira acumularam mais aos 90 dias, os grãos aos 110 dias e as espigas não apresentaram difarenças ao longo de seu desenvolvimento.

Entre as partes estudadas, os gräos apresentaram maior acümulo de nitrogento nas duas cultivares, independente da disponibilidade de água, mostrando assin haver consi derivel exportação do nutriente pelas colneitas. 
O conteúdo de nitrogénio nos graos segundo ALS TON (1980) reduz com o alimento no número de irrigações, resultado que concorda com os obtidos neste trabalhc, apesar de ocorrér o contrário com o acúmulo, o qual nesta situação é dependente da produção de matēria seca. WALDREN \& FLONERDAY (1979) em estudos de absorção de nitrogênio pela planta de trigo, mostram que cerca de $2 / 3$ do $N$ das folhas e menor quanîdade do colmo e espigas são tránsferidos para o grão, sendo transferidos para este ültimo aproximadamente $71 \%$ do total. Nesta pesquisa, nas duas cultivares e disponibilidades dé água a transferência para o grão foi entre $59 \%$ e $71 \%$ (Tabelas 20 e 21). MCNEAL et alii (1966) estudando o acúmulo de nutrientes nas partes das plantas de cinco cultivares, verificou que o máximo acümulo de nitrogênio nas folhas ocorre na floraçäo, ocorrendo a partir daí acentuado decínio para um aumento cres cente nos grãos, os quais nas cultivares "Chinook"e "pl 266148 " apresentaram $61,6 \%$ e $61,2 \%$, respectivamente do total acumulado na planta inteira, sendo que, segundo os autores o máximo verificado em outras cultivares foi $70 \%$.

\subsubsection{FOSFORO}

As médias em mg e os percentuais de fösoro nos örgãos da plarta, nas idades de 90 e 110 dias, das duas cult vares en duas disponibilidades de água estão apresentados na Tabela 9. As partes da planta da cultivar an 1146 nas dus 
Tabela 9. Teores médios de fósforo contidos nas partes da planta de duas cultivares de trigo estudadas em duas disponibilidades de água.

\begin{tabular}{|c|c|c|c|c|c|c|c|c|}
\hline \multirow{4}{*}{$\begin{array}{l}\text { Idade } \\
\text { da } \\
\text { planta } \\
\text { (dias) }\end{array}$} & \multicolumn{8}{|c|}{ Cultivar. } \\
\hline & \multicolumn{4}{|c|}{ BH 1146} & \multicolumn{4}{|c|}{ IAC 24-Tucuruí } \\
\hline & \multicolumn{8}{|c|}{ Disponibilidade de água } \\
\hline & \multicolumn{2}{|c|}{ Seque i ro } & \multicolumn{2}{|c|}{ Irrigado } & \multicolumn{2}{|c|}{ Sequeiro } & \multicolumn{2}{|c|}{ Irrigado } \\
\hline$=$ & $\mathrm{mg} / \mathrm{pl}$ & $\%$ & $m g / p l$ & $\%$ & $\mathrm{mg} / \mathrm{pl}$ & $\%$ & $\mathrm{mg} / \mathrm{pl}$ & $\%$ \\
\hline & & & & COLMO & & & & \\
\hline 90 & $0,18 \mathrm{Ba}$ & 0,01 & $0,5 i \mathrm{Aa}$ & 0,02 & $0,20 \mathrm{Ba}$ & 0,02 & $0,77 \mathrm{Aa}$ & 0,04 \\
\hline 110 & $0,198 \mathrm{~B}$ & 0,02 & $0,40 \mathrm{Aa}$ & 0,02 & $0,10 B a$ & 0,01 & $0,45 \mathrm{Ab}$ & 0,02 \\
\hline & & & . & FO!HA & & & & \\
\hline 90 & $0,10 B a$ & 0,03 & $0,33 \mathrm{Aa}$ & 0,05 & $0,055 a$ & 0,01 & $0,3] \mathrm{Aa}$ & 0,05 \\
\hline 110 & 0,0 A Aa & 0,02 & $0,15 \mathrm{Aa}$ & 0,03 & $0,09 \mathrm{Aa}$ & 0,02 & $0,19 \mathrm{Aa}$ & 0,03 \\
\hline & & . & & FOLHA & BANDE!RA & & & \\
\hline 90 & $0,03 B a$ & 0,04 & $0,14 \mathrm{Aa}$ & 0,08 & $0,048 \mathrm{a}$ & 0,03 & $0,23 \mathrm{Aa}$ & 0,09 \\
\hline 110 & $0,02 \mathrm{Aa}$ & 0,02 & $0,03 \mathrm{Ab}$ & 0,03 & $0,01 \mathrm{Aa}$ & 0.01 & $0,01: A B$ & 0,02 \\
\hline & & & & GRAO & & & & \\
\hline 90 & $2,30 \mathrm{Ba}$ & 0,28 & $4,03 \AA a$ & 0,33 & $2,548 \mathrm{a}$ & 0,24 & $3,48 \mathrm{Ab}$ & $0,2 \hat{0}$ \\
\hline 110 & $1,95 \mathrm{Ba}$ & 0,25 & $3,39 \mathrm{Aa}$ & 0,30 & $2,283 \mathrm{a}$ & 0,22 & $5,48 \mathrm{Aa}$ & 0,27 \\
\hline . & & & & ESPIGA & & & & \\
\hline so & $0,158 \mathrm{~B}$ & 0,04 & $0,38 \mathrm{Aa}$ & 0,06 & $0,163 a$ & 0,04 & $0,78 \mathrm{Aa}$ & 0,09 \\
\hline 110 & $0,23 \mathrm{Ba}$ & 0,06 & $0,41 \mathrm{Aa}$ & 0.07 & $0,278 a$ & 0,04 & $0,67 \mathrm{Aa}$ & 0,07 \\
\hline
\end{tabular}

- Para cada cuitivar, dentro de cada linha, as médias seguidas da mesme letra maiuscula e dentro de cacia coluna para cada parte da planta, as mëdias de idade seguidas da mesma letra minuscula näo diferem significa tivämente entre si, pelo teste de Tukey ao nivel de $5 \%$ de probabilida die. 
idades apresentaram maior acúmulo de fósforo quando receberam irrigação, com excessão das folhas e folhas bandeira que com 110 dias de idade não mostraram diferenças. Na cultivar laC 24-Tucuruí, somente nas folhas bandeira na maturação da planta, não houve diferença no acúmulo entre o tratamento sequei ro e irrigado, sendo que nas demais partes e idades o último tratamento proporcionou maior ácúmulo.

$\because$.

Com relação a idade da planta, a cultivar EH 1146 mostrou não haver diferenças de acúmulo de fósforo nas diferentes partes com a variação de idade, com excessão das fo Ihas bandeira, no tratamento irrigado que acumulou maior peso aos 90 dias. Na cultivar IAC 24-Tucurui em sequeiro, todas as partes e com irrigação as fol has e espigas não mostraramdi ferenças entre idades; os colmos e folhas bandeira acumularam maior peso com 90 dias de idade e o grão no final do cicio.

os grãos produzidos, pelas duas cultivares nas duas disponibilidades de água, foi o órgão que mostrou maior acúmulo de fósforo. Em regime de sequeiro os grãos acumularam no final do ciclo $80 \%$ e $83 \%$ nas cultivares BH 1146 e IAC 24-Tucurui, respectivamente e $77 \%$ e $80 \%$, para as mesmas culti vares, do total acumulado pela planta inteira. Em estudos de absorção, dristribuição de matéría seca e nuterientes nos dife rentes órgãos da planta de trigo, VALDREN \& flowerofy (1979) mostram que na maturação os grãos contén $75 \%$ do total de fósfo ro absorvido, valor próximo aos atingidos nesta pesquisa.

BASSIRI \& MAHAFETIAN (1977), estudanto as G:- 
ferenças entre concentração de nutrientes nos grãos das culti vares mexicanas de trigo "Penjamo" e "Tobari", em regime de sequeiro e irrigado, constataram em média $0,36 \%$ e $0,41 \%$ de P para as duas disponibilidades de água, respectivamente.

\subsubsection{POTASSIO}

Os pesos médios em mg e percentuaís de potás sio nos örgäos das plantas de duas cultivares, nas idades de 90 e 110 dias, estudadas em duas disponibilidades de àgua estão apresentados na Tabela 10. Na cultivar BH 1146, os colmos e grãos nas duas idales mostraram maior acümulo do nutriente quando a planta recebeu irrigeção, acontecendo de forma semelhante coni as folhas e folhas bandeira aos 90 dias de idade; sendo que as folhas aos 110 dias e espigas nas duas idades não mostraram diferenças nas duas disponibilidades òe àgua e as folthas bandeira aos 110 dias de idade acumularam maior quant dade com o regime de sequeiro.

os colmos, folhas bandeira espigas das plantas da cultivar IAC 24-Tucuruí mostraram maior acúmulo de potăssio em regime irrigado, independente da idacie estudada; nas folhas aos 90 dias houve maior acümulo atravexs do regime de sequeiro a no final do ciclo não houve difarença entre disponibilidades de água; nos grãos no final do ciclo o maior a-

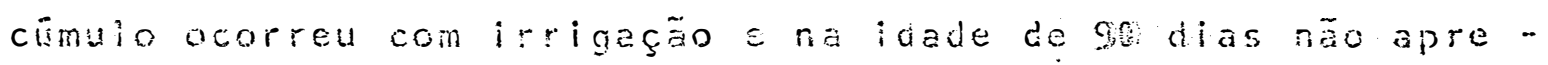
sertoli diferenga. 
Tabela 10. Teores médios de potássio contidos nas partes da planta deduas cultivares de trigo estudadas em duas disponibilidades de áqua.

\begin{tabular}{|c|c|c|c|c|c|c|c|c|}
\hline \multirow{4}{*}{$\begin{array}{l}\text { Idade } \\
\text { da } \\
\text { Planta } \\
\text { (dias) }\end{array}$} & \multicolumn{8}{|c|}{ Cultivar } \\
\hline & \multicolumn{3}{|c|}{ BH 1146} & \multicolumn{5}{|c|}{ IAC 24-Tucurui } \\
\hline & \multicolumn{8}{|c|}{ Disponibilidade de ãgua } \\
\hline & \multicolumn{2}{|c|}{ Seque iro } & \multicolumn{2}{|c|}{ Irrigado } & \multicolumn{2}{|c|}{ Seque iro } & \multicolumn{2}{|c|}{ Irrigado } \\
\hline$\cdot \ldots$ & $\mathrm{mg} / \mathrm{pl}$ & $\%$ & $\mathrm{mg} / \mathrm{pl}$ & $\begin{array}{c}\% \\
\text { COLMO }\end{array}$ & $\mathrm{mg} / \mathrm{pl}$ & 8 & $\mathrm{mg} / \mathrm{pl}$ & $\%$ \\
\hline 90 & $19,71 \mathrm{Ba}$ & 1,61 & $39,42 \mathrm{Aa}$ & 1,68 & $15,42 \mathrm{Ba}$ & 1,34 & $35,54 \mathrm{Aa}$ & $i, 72$ \\
\hline 110 & $17,10 \mathrm{Ba}$ & 1,53 & $33,73 \mathrm{Aa}$ & $\begin{array}{l}1,68 \\
\text { FoL }\end{array}$ & $13,61 \mathrm{Ba}$ & 1,33 & $40,27 \mathrm{Aa}$ & 2,01 \\
\hline 90 & $3,40 B a$ & 0,95 & $11,79 \mathrm{Aa}$ & 1.87 & 3,6382 & 1,09 & $10,75 \mathrm{Aa}$ & 1,82 \\
\hline 110 & $2,50 \mathrm{Aa}$ & 0,80 & $3,20 \mathrm{AD}$ & $\begin{array}{l}0,57 \\
\text { FOLHA }\end{array}$ & $\begin{array}{r}4,02 A a \\
\text { BANDE IRA }\end{array}$ & 1,03 & $5,73 \mathrm{Ab}$ & 0,88 \\
\hline 90 & $0,673 \mathrm{Bb}$ & 0,78 & $2,56 \mathrm{Aa}$ & 1,41 & $1,37 \mathrm{Ba}$ & 1,14 & $4,56 \mathrm{Aa}$ & 3,72 \\
\hline 110 & $1,74 \mathrm{Aa}$ & 1,68 & $0,610 b$ & $\begin{array}{l}0,61 \\
\text { GRTOO }\end{array}$ & $1,12 \mathrm{Ba}$ & 1,57 & $1,80 \mathrm{Ab}$ & 1,09 \\
\hline 90 & $2,70 \mathrm{Ba}$ & 0,33 & $5,07 \mathrm{Aa}$ & 0,42 & 4.7942 & 0,45 & $5,85 \mathrm{Ab}$ & 0,48 \\
\hline 110 & $2,70 B a$ & 0,35 & $4,28 \mathrm{Aa}$ & 0,35 & 3,5983 & $0 ! 35$ & $9,42 \mathrm{Aa}$ & 0,46 \\
\hline & & & & ESPIGA & & & & \\
\hline 90 & $2,35 \mathrm{Aa}$ & 0,63 & $2,89 \mathrm{Aa}$ & 0,50 & $4,188 a$ & 0,67 & $7,78 \mathrm{Aa}$ & 0,38 \\
\hline 110 & $2,13 A a$ & 0,53 & $1,33 \mathrm{Ab}$ & 0,25 & $3,92 \mathrm{Ba}$ & $a, a$ & $5,01 \mathrm{ab}$ & 0,50 \\
\hline
\end{tabular}

- Para cada cultivar, dentro de cada linha, as méthias seguidas da mesma letra maiúscula e dentro de cada coluna para cala nerte da planta, as mêdias de idade seguidas da mesne letra minúscule mo diferem sianificativamente entre si, pelo teste de Tukey ao niwal je $5 \%$ de probabi!idade. 
Os colmos e o grão da cultivar BH 1146 não apre sentaram diferenças no conteüdo de potássio com o aumento da idade, independente da disponibilidade de áqua, o mesmo ocor rendo com as folhas e espigas no regime de sequeiro, as quais em reigme irrigado acumularam o máximo dos 90 dias; sendo que as folhas bandeira em reigme de sequeiro mostrou maior valor aos 110 dias e com irrigação aos 90 dias. Todas as partes estudadas da cultivar IAC 24-Tucuruí, em sequeiro, não apre sentaram alteração na quantidade acumulada de potássio com a idade, sendo que com irrigação as folhas, forthas bandeira e espigas apresentaram maior acúmulo com 90 dias de idade e grãos no final do ciclo, não havendo diferença nos colmos com a idade.

No final do ciclo, as cultivares estudadas nas duas disponibilidades de água mostram acúmulo de potássio nos grãos entre $10 \%$ e $15 \%$, sendo que o órgão mais acumulador de potássio foram os colmos com valores médios de $65 \%$ (Tabelas 19 e 20$)$.

GREGORY et alii (1979) trabahando com experimentos em condições de campo para estudar a acúmulo e distribuiçäo de $N a, K, C a, M g, P, S$ e $N$ nas plantas de trigo, verificaram que a concentraçäo de K, $P$ e $N$ é geralmente maior nos colmos do que nas folhas, sendo que a concentração nas folthas e espigas decrescem com a idade e nos colmos há estabilidade até o final da colheita. Os resultados obtidos com potásio sáo concordantes aos de PAGE et ali i (1977) a qual mostra que 
o teor de potássio e cálcio decrescem nas espigas com a idade.

os resultados obtidos na presente pesquisa são concordantes aos encontrados na literatura.

\section{3 .5 CALC10}

Os pesos em mg e percentuais médios de cálcio alcançados pelos órgãos das plantas das cultrivares BH 1146 e IAC 24-Tucurui em duas disponibilidades de água estão apresen tados na Tabela 11. A primeira cultivar mostrou nos colmos, nas folhas bandeira aos 90 dias de idade e nas folhas nas duas idades, o maior acümulo de cálcio no reglime de sequei ro ; já com lío dias de idade os colmos e folthas bandeira não mostraram diferenças entre as disponibilidadles de água; os grãos acuniularam maior quantidade aos 110 dilles atrávés do tra tamento irrigado e as espigas não mostraran differenças de acü mulo com as disponibilidades de água em quallquer das idades.

A cultivar IAC 24-Tucurui, mostrou nas folhas

e folhas bandeira, maior acúmulo do nutriente com o tratamento irrigado, nas duas idades; os colmos näe mostraram diferen ças aos 90 e 110 dias; sendo que os grãos espigas no finai do ciclo apresentaram maior quantidade de allo quando receberam irrigaçăo, ocorrendo igualdade aos gia dias.

Em sequeiro a cultivar Bh l146 mostrou maior acúmuio nos colmos, gräos e espigas no final do cicio e nas 
Tabela 11. Teores médios de cálcio contidos nas partes da planta de duas cultivares de trigo estudadas em duas disponibilidades de àgua.

\begin{tabular}{|c|c|c|c|c|c|c|c|c|}
\hline \multirow{5}{*}{$\begin{array}{l}\text { Idade } \\
\text { da } \\
\text { planta } \\
\text { (dias) }\end{array}$} & \multicolumn{8}{|c|}{ Cultivar } \\
\hline & \multicolumn{4}{|c|}{$\mathrm{BH} 1146$} & \multicolumn{4}{|c|}{ IAC 24-Tucurui } \\
\hline & \multicolumn{8}{|c|}{ Disponibilidade de água } \\
\hline & \multicolumn{2}{|c|}{ Seque i ro } & \multicolumn{2}{|c|}{ Irrigado } & \multicolumn{2}{|c|}{ Seque i ro } & \multicolumn{2}{|c|}{ Irrigado } \\
\hline & $\mathrm{mg} / \mathrm{pl}$ & $\%$ & $\mathrm{mg} / \mathrm{pl}$ & $\%$ & $\mathrm{mg} / \mathrm{pl}$ & $\%$ & $\mathrm{mg} / \mathrm{pl}$ & $\%$ \\
\hline & & & & COLMO & & & & \\
\hline 90 & $1,82 \mathrm{Ba}$ & 0,15 & $2,83 \mathrm{Aa}$ & 0,12 & $1,50 \mathrm{Aa}$ & 0,13 & $1,77 \mathrm{Aa}$ & 0,08 \\
\hline \multirow[t]{2}{*}{110} & $0,87 \mathrm{Ab}$ & 0,08 & $1,51 \mathrm{Aa}$ & 0,07 & $1,33 \mathrm{Aa}$ & 0,13 & $2,04 \mathrm{Aa}$ & 0,10 \\
\hline & & & & FOLHA & & & & \\
\hline 90 & $1,64 \mathrm{Ba}$ & 0,46 & $3,10 \mathrm{Aa}$ & 0,49 & $1,70 \mathrm{Ba}$ & 0,46 & $2,71 \mathrm{Aa}$ & 0,46 \\
\hline \multirow[t]{2}{*}{110} & $1,39 \mathrm{Ba}$ & 0,45 & $2,59 \mathrm{Aa}$ & 0,46 & $1,46 \mathrm{Ba}$ & 0,38 & $3,00 \mathrm{Aa}$ & 0,46 \\
\hline & \multicolumn{8}{|c|}{ FOLHA BANDEIRA } \\
\hline 90 & $0,27 \mathrm{Bb}$ & 0,31 & $1,01 \mathrm{Aa}$ & 0,59 & $0,49 B a$ & 0,40 & $1,25 \mathrm{Aa}$ & 0,47 \\
\hline \multirow[t]{2}{*}{110} & $0,65 \mathrm{Aa}$ & 0,62 & $0,59 \mathrm{Ab}$ & 0,59 & $0,34 \mathrm{Ba}$ & 0,48 & $0,74 \mathrm{Ab}$ & 0,45 \\
\hline & & & & GRAOO & & & & \\
\hline 90 & $0,44 \mathrm{Aa}$ & 0,05 & $0,52 \mathrm{Aa}$ & 0,04 & $0,51 \mathrm{Aa}$ & 0,05 & $0,51 \mathrm{Aa}$ & 0,04 \\
\hline \multirow[t]{2}{*}{110} & $0,25 \mathrm{Bb}$ & 0,03 & $0,49 \mathrm{Aa}$ & 0,04 & $0,31 \mathrm{Bb}$ & 0,03 & $0,61 \mathrm{Aa}$ & 0,03 \\
\hline & & & & ESPIGI & & & & \\
\hline 90 & $0,49 \mathrm{Aa}$ & 0,13 & $0,52 \mathrm{Aa}$ & 0,09 & $0,77 \mathrm{Aa}$ & 0,12 & $0,87 \mathrm{Aa}$ & 0,10 \\
\hline 110 & $0,34 \mathrm{Ab}$ & 0,09 & $0,47 \mathrm{Aa}$ & 0,09 & $0,69 \mathrm{Ba}$ & 0,11 & $1,01 \mathrm{Aa}$ & 0,10 \\
\hline
\end{tabular}

- Para cada cultivar, dentro de cada linha, as médias seguidas da mesma letra maiúscula e dentro de cada coluna para cada parte da planta, as médias de idade seguidas da mesma letra minúscula não diferem significativamente entre si, pelo teste de Tukey ao nivel de $5 \%$ de probabilidade. 
folhas bandeira aos 90 dias, sendo que as folhas não mostraram diferenças; com irrigação apenas as folhas bandeira mostraram aumento com a idade, não sendo verificadas diferenças nas demais partes. A cultivar IAC 24-Tucurui, nas duas disponibilidades de água não mostrou diferenças de acúmulo nas par tes com a idade, com excessão das folhas bandeira em regime irrigado e os grãos em 'sequeiro que decresceram com a idade.

Os órgãos mais acumuladores de cálcio, nas duas cultivares e disponibilidades de água, foram os colmos e foIhas, sendo que as ültimas apresentaram maior teor em relação as demais partes.

KARLEN \& WHITNEY (1980) atravès de estudos de absorção e distribuição de nutrientes nas partes da planta de trigo, mostram que a concentração de cálcio nas follhas e colmos decresce até a maturação fisiológica e nas espigas da flo ração a maturação é caracterizada pọ variações, sendo que na espiga os teores se apresentam constantes desde a sua formação até a maturação. Com relação a disponibilidade de água, BASSIRI E NAHAPETIAN (1977) mostram a ocorrência de maiores teores através de tratamentos sem irrigação, principalmente, nas folhas e colmos, já as maiores diferenças entre cultivares foram obtidas com tratamentos irrigados. Na presente pesquisa, nos órgãos de ma ior a cúmulo, folthas e colmos, não foram encontradas diferenças entre cultivares, independentemente da disponibilidade de àgua. 


\subsubsection{MAGNESIO}

Na Tabela 12, estão apresentados os pesos em mg e percentuais médios de magnésio encontrados nos órgãos das duas cultivares de trigo, em duas disponibillidades de ägua. A cultivar BH 1146 mostrou em todas as partes maior acúmulo do nutriente com o tratamento irrigado, sendo que no final do ciclo os colmos, folhas, folhas bandeira e espigas não mostra ram diferenças estatísticas com a restrição de água, já os grãos mostraram maior acúmulo no regime irrigado. A cultivar IAC 24-Tucuruí aos 90 dias de idade não mostrou diferença no acūmulo de magnésio com as diferentes idades nos colmos, foIhas, grãos e espigas, já no final do ciclo todas as partes mostraram maiór acúmulo no regime irrigado.

Com relação a idade a cultivar BH 1146 em sequeiro não mostrou diferenças quanto ao acúmulo nas partes ana lisadas, com excessão das folhas que armazenaram maior quant dade aos 90 dias e com irrigação o maior acúmulo para as partes ocorreu com 110 dias de idade, no entanto, os grãos não mostraram diferenças com a idade. A cultivar IAC 24 -Tucurui em sequeiro acumulou maior quantidade aos 90 dias nas folhas, grãos e espigas, nos colmos e folhas bandeira não ocorreram diferenças com a idade, com irrigação esta culltivar näo mostrou diferenças com a idade nas folhas e esplgas, nos colmos e grãos houve maior acúmulo no final do ciclo e nas folthas ban deira aos 90 dias de idade. 
Tabela 12. Teóresmédios de magnésio contidos nas partes da planta de duas cultivares de trigo estudadas em duas disponibilidades de água.

\begin{tabular}{|c|c|c|c|c|c|c|c|c|}
\hline \multirow{5}{*}{$\begin{array}{c}\text { Idade } \\
\text { da } \\
\text { planta } \\
\text { (dias). }\end{array}$} & \multicolumn{7}{|c|}{ Cultivar } & \\
\hline & \multicolumn{4}{|c|}{ BH 1146} & \multicolumn{4}{|c|}{ IAC 24-Tucuruí } \\
\hline & \multicolumn{8}{|c|}{ Disponibilidade de āgua. } \\
\hline & \multicolumn{2}{|c|}{ Seque i ro } & \multicolumn{2}{|c|}{ Irrigado } & \multicolumn{2}{|c|}{ Seque i ro } & \multicolumn{2}{|c|}{ Irrigado } \\
\hline & $\mathrm{mg} / \mathrm{pl}$ & $\%$ & $\mathrm{mg} / \mathrm{pl}$ & $\%$ & $\mathrm{mg} / \mathrm{pl}$ & $\%$ & $\mathrm{mg} / \mathrm{pl}$ & $\%$ \\
\hline & $\therefore$ & & & COLMO & & & & \\
\hline 90 & $1,41 \mathrm{Ba}$ & 0,12 & $2,11 \mathrm{Aa}$ & 0,09 & $1 ; 01 \mathrm{Aa}$ & 0,09 & $1,10 \mathrm{Ab}$ & 0,05 \\
\hline 110 & $1,10 \mathrm{Aa}$ & 0,09 & $1,14 \mathrm{Ab}$ & 0,06 & $0,69 \mathrm{Ba}$ & 0,07 & $1,60 \mathrm{Ba}$ & 0,08 \\
\hline & & & & FOLLHA &. & & & \\
\hline 90 & $0,998 \mathrm{a}$ & 0,28 & $1,77 \mathrm{Aa}$ & 0,28 & $1,08 \mathrm{Aa}$ & 0,29 & $1,11 \mathrm{Aa}$ & 0,19 \\
\hline 110 & $0,53 \mathrm{Ab}$ & 0,17 & $0,80 \mathrm{Ab}$ & 0,14 & $0,71 \mathrm{Bb}$ & 0,18 & $1,15 \mathrm{Aa}$ & 0,18 \\
\hline 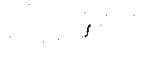 & & & & FOLHA & BANDEIRA & & & \\
\hline 90 & $0,19 \mathrm{Ba}$ & 0,22 & $0,60 \mathrm{Aa}$ & 0,31 & $0,38 \mathrm{Ba}$ & 0,32 & $0,67 \mathrm{Aa}$ & 0,28 \\
\hline 110 & $0,28 \mathrm{Aa}$ & 0,25 & $0,23 \mathrm{Ab}$ & 0,23 & $0,23 \mathrm{Ba}$ & 0,33 & $0,46 \mathrm{Ab}$ & 0,25 \\
\hline & & & & GRÃO & & & & \\
\hline 90 & $1,75 \mathrm{Ba}$ & 0,25 & $2,47 \mathrm{Aa}$ & 0,20 & $2,35 \mathrm{Aa}$ & 0,22 & $1,99 \mathrm{Ab}$ & 0,16 \\
\hline 110 & $1,19 \mathrm{Ba}$ & 0,15 & $1,75 \mathrm{Aa}$ & 0,14 & $1,20 \mathrm{Bb}$ & 0,12 & $3,13 \mathrm{Aa}$ & 0,15 \\
\hline & & & & ESPIG/ & & & & \\
\hline 90. & $0,62 \mathrm{Aa}$ & 0,17 & $0,88 \mathrm{Aa}$ & 0,15 & $1,12 \mathrm{Aa}$ & 0,18 & $1,06 \mathrm{Aa}$ & 0,12 \\
\hline 110 & $0,46 \mathrm{Aa}$ & 0,11 & $0,49 \mathrm{Ab}$ & 0,09 & $0,72 \mathrm{Ab}$ & 0,11 & $0,94 \mathrm{Aa}$ & 0,09 \\
\hline
\end{tabular}

Para cada cultivar, dentro de cada linna, as médias seguidas da mesma letra maiúscula e dentro de cada coluna para cada parte da planta, as médias de idade seguidas da mesma letra minúscula näo diferem significa tivamente entre si, pelo teste de Tukey ao nivel de $5 \%$ de probabilida de. 
As partes mais acumuladoras de magnésio em ambas as cultivares e disponibilidades de água foram os grãos e colmos, na irrigação houve maior acúmulo nos grãos da cultivar IAC 24-Tucuruí (Tabelas 19 e 20). PAGE et alii. (1977) verificaram que a planta apresenta conteúdos máximos de magnésio quando inicia o aparecimento do pseudo colmo decrescendo até o estádio da antese, ocorrendo nas espigas e grãos cresci mento assintótico desde o seu aparecimento até a maturação. Na folhagem decresce abruptamente até o final da maturaçãoem função da transferência para as espigas.

Em concordância a esta pesquisa FURLANI - et alii (1977) trabalhando com as cultivares de arroz "IR 665", "IAC $435^{\prime \prime}$ e "IAC $120 "$ mostram que os órgãos mais acumuladores de magnésio são os grãos descascados e cascas e que as culti vares diferem entre si no acúmulo deste nutriente naqueles ór gãos .

\subsubsection{ENXOFRE}

Na Tabela 13 estão apresentadas as quantidadẹs em mig e percentuais médios de enxofre determinados nas partes das plantas de duas cultivares em regime de sequeiro e irriga ção. As plantas da cultivar BH 1146 mostram nos colmos e foThas aos 90 dias, maior acúmulo do nutriente em regime irriga do, no entanto, estas mesmas partes aos 110 dias e as demais não apresentam diferenças com a disponibididade de ägua. 
Tabela 13. Teores médios de enxofre contidos nas partes da planta de duas cultivares de trigo estudadas emduas disponibilidades de água.

\begin{tabular}{|c|c|c|c|c|c|c|c|c|}
\hline \multirow{5}{*}{$\begin{array}{l}\text { Idade } \\
\text { da } \\
\text { planta } \\
\text { (dias) }\end{array}$} & \multicolumn{8}{|c|}{ Cultivar } \\
\hline & \multicolumn{4}{|c|}{$\mathrm{BH} 1146$} & \multicolumn{4}{|c|}{ IAC 24-Tucuruí } \\
\hline & & & Dispon i & oilida & e de äguá & & & \\
\hline & \multicolumn{2}{|c|}{ Sequei ro } & \multicolumn{2}{|c|}{ Irrigado } & \multicolumn{2}{|c|}{ Sequeiro } & \multicolumn{2}{|c|}{ Irrigado } \\
\hline & $\mathrm{mg} / \mathrm{pl}$ & $\%$ & $\mathrm{mg} / \mathrm{pl}$ & $\%$ & $\mathrm{mg} / \mathrm{pl}$ & $\%$ & $\mathrm{mg} / \mathrm{pl}$ & $\%$ \\
\hline & & & & COLMO & & & & \\
\hline 90 & $5,83 \mathrm{Ba}$ & 0,47 & $8,52 \mathrm{Aa}$ & 0,36 & $4,68 \mathrm{Ba}$ & 0,41 & $6,49 A a$ & 0,31 \\
\hline 110 & $3,48 \mathrm{Ab}$ & 0,31 & $4,79 A b$ & 0,24 & $2,17 \mathrm{Bb}$ & 0,22 & $5,20 \mathrm{Aa}$ & 0,26 \\
\hline & & & & FOLHA & & & & \\
\hline 90 & $1,68 \mathrm{Ba}$ & 0,47 & $2,37 \mathrm{Aa}$ & 0,37 & $1,61 \mathrm{Aa}$ & 0,43 & $1,62 \mathrm{Aa}$ & 0,27 \\
\hline 110 & $0,89 \mathrm{Ab}$ & 0,29 & $1,13 A b$ & 0,20 & $0,83 \mathrm{Bb}$ & 0,22 & $1,56 \mathrm{Aa}$ & 0,24 \\
\hline & & & & FOLHA & BANDE |RA & & & \\
\hline 90 & $0,36 \mathrm{Ba}$ & 0,41 & $0,61 \mathrm{Aa}$ & 0,33 & $0,46 \mathrm{Ba}$ & 0,40 & $0,69 A a$ & 0,26 \\
\hline 110 & $0,33 \mathrm{Aa}$ & 0,32 & $0,25 \mathrm{Ab}$ & 0,24 & $0,10 ́ \mathrm{Bb}$ & 0,23 & $0,47 \mathrm{Aa}$ & 0,29 \\
\hline & & & & GRÃO & & & & \\
\hline 90 & $3,47 \mathrm{Aa}$ & 0,42 & $4,37 \mathrm{Aa}$ & 0,25 & $4,56 \mathrm{Aa}$ & 0,43 & $3,16 \mathrm{BD}$ & 0,26 \\
\hline 110 & $2,04 \mathrm{Ab}$ & 0,27 & $3,04 \mathrm{Aa}$ & 0,36 & $2,29 B b$ & 0,22 & $5,68 \mathrm{Aa}$ & 0,28 \\
\hline & & & & ESP $1 G$ & & & & \\
\hline 90 & $1,31 \mathrm{Aa}$ & 0,35 & $1,87 \mathrm{Aa}$ & 0,33 & $2,68 \mathrm{Aa}$ & 0,42 & $2,12 \mathrm{Aa}$ & 0,24 \\
\hline 110 & $1,12 \mathrm{Aa}$ & 0,29 & $1,23 \mathrm{Ab}$ & 0,23 & $1,32 \mathrm{Ab}$ & 0,20 & $2,12 \mathrm{Aa}$ & 0,21 \\
\hline
\end{tabular}

- Para cada cultivar, dentro de cada linta, as médias seguidas da mesma letra maíuscula e dentro de cada coluna para cada parte da planta, as mëdias de idade seguidas da mesma letra minúscula não diferem significa tivamente entre si, pelo teste de Tukey ao nivel de $5 \%$ de probabilidá de. 
cultivar IAC 24-Tucuruí apresenta nos colmos e folhas bandeira maior acūmulo atravēs da irrigação, as follhas e grãos somente apresentaram este mesmo comportamento no final do ciclo e as espigas não mostraram diferenças com a alteração de suprimento de àgua.

Com o aumento da idade a cultivar BH 1146 em sequeiro e com irrigação, nas cinco partes estudadas decres ceu o conteúdo de enxofre, havendo igualdade nas folhas bandeira e espigas em sequeiro e folhas bandeira em regime irrigado

Tanto o acúmulo do nutriente nas partes. da planta como o teor mostraram-se iguais com excessão das folhas bandeira que foram os örgãos com menor acúmulo, no entan to seus teores foram elevados.

GARGANTINI \& BLANCO (1973) determinaram em ambiente controlado a composição quínica de duas cultivares de trigo em treze diferentes idades. Na maturaçáo final encontra ram na cultivar $B H 1146,0,28 \%, 0,30 \%, 0,36 \%$ e $0,34 \%$ de enxofre nas rá́zes, parte aérea, espigas e grãos, respectivamen te; para a IAS 3795 , na mesma sequência, $0,16 \%, 0,38 \%, 0,38 \%$ e $0,23 \%$. GIUOICE et alii (1983) estudando a distribuição de nutrientes nas partes da planta de arroz, verificaram a tendência de aumento do teor de enxofre nas partes vegetativas com a restrição de água. Os resultados obtidos com arroz foram semelhantes a esta pesquisa, onde na cultivar BH 1145 foram encontrados os maiores teores deste nutriente em sequei- 
ro, com menores diferenças para a cultivar IAC 24-Tucuruí. Em trigo RASMUSSEN et alii (1975) constataram que os teores de enxofresão inferiores aos trabalhos anteriores e à presen te pesquisa, verificaram que os teores nos grãos atingem valores entre $0,09 \%$ e $0,16 \%$ e na parte aérea entre $0,03 \%$ e $0,10 \%$, em diversos anos de cultivo.

\subsubsection{BORO}

As médias em mg por planta e as quantidades em ppm, de boro nos órgãos das plantas de trigo de duas cultivares sob a influência de duas disponibilidades de água, aos 90 e 110 dias de idade, estão apresentadas na Tabela 14. As folhas bandeira, grãos e espigas da cultivar BH 1146 não mostra ram diferenças no acūmulo do micronutriente com as diferentes disponibilidades de água; os colmos e folhas armazenaram, no final do ciclo, maior quantidade com o tratamento irrigado. Todas as partes da cultivar IAC 24-Tucuruí não mostraram diferenças em acúmulo com a variação de disponibilidade de āgua, com excessão dos grãos que, na maturação final acumulạram maicr peso no tratamento irrigado.

Com o aumento da idade, a cultivar BH 1146 en sequeiro não modificou o acümulo nas folhas, folhas bandeira e espigas, nos colmos e grãos houve decrëscimo; com irrigação esta cultivar manteve inalterados os pesos em todos os órgãos com excessão das folhas que apresentaram irescimento com a 
Tabela 14. Teores médios de boro contidos nas partes da planta de duas cultivares de trigo estudadas em duas disponibilidades de ägua.

\begin{tabular}{|c|c|c|c|c|c|c|c|c|}
\hline \multirow{5}{*}{$\begin{array}{l}\text { Idade } \\
\text { da } \\
\text { planta } \\
\text { (dias) }\end{array}$} & \multicolumn{8}{|c|}{ Cultivar } \\
\hline & \multicolumn{4}{|c|}{ BH 1146} & \multicolumn{4}{|c|}{ IAC 24-Tucuruí } \\
\hline & \multirow{2}{*}{\multicolumn{2}{|c|}{ Seque i ro }} & \multicolumn{4}{|c|}{ Disponibilidade de água } & & \\
\hline & & & Irrigad & & Seque ir & & Irrigad & \\
\hline & $\mu g / p l$ & $\mathrm{ppm}$ & $\mu g / p l$ & $\begin{array}{l}\text { Ppm } \\
\text { COLMO }\end{array}$ & $\mu g / p l$ & ppm & $\mu g / p l$ & $\mathrm{ppm}$ \\
\hline 90 & $18,54 \mathrm{Aa}$ & 15,05 & $21,17 \mathrm{Aa}$ & 9,32 & $16,27 \mathrm{Aa}$ & 14,37 & $15,74 \mathrm{Aa}$ & 7,67 \\
\hline 110 & $8,92 \mathrm{Bb}$ & 8,45 & $21,41 \mathrm{Aa}$ & $\begin{array}{l}10,70 \\
\text { FOLHA }\end{array}$ & $11,51 \mathrm{Aa}$ & 11,72 & $11,87 \mathrm{Aa}$ & 5,97 \\
\hline 90 & $10,00 \mathrm{Aa}$ & 28,55 & $7,20 \mathrm{Ab}$ & 11,40 & $7,74 \mathrm{Aa}$ & 21,45 & $6,34 \mathrm{Ab}$ & 10,67 \\
\hline 110 & $6,04 \mathrm{Ba}$ & 19,67 & $11,84 \mathrm{Aa}$ & $\begin{array}{l}21,05 \\
\text { FOLHA }\end{array}$ & $\begin{array}{l}11,56 \mathrm{Aa} \\
\text { BANDE IRA }\end{array}$ & 29,62 & $10,83 \mathrm{Aa}$ & 16,75 \\
\hline 90 & $3,62 \mathrm{Aa}$ & 40,77 & $2,54 \mathrm{Aa}$ & 28,12 & 3,39 A.a & 31,13 & $2,96 \mathrm{Aa}$ & 23,17 \\
\hline 110 & $2,45 \mathrm{Aa}$ & 24,82 & $2,86 \mathrm{Aa}$ & $\begin{array}{l}13,57 \\
\text { GRÃO }\end{array}$ & $3,18 \mathrm{Aa}$ & 44,97 & $3,83 \mathrm{Aa}$ & 11,05 \\
\hline 90 & $7,22 \mathrm{Aa}$ & 8,65 & $4,92 \mathrm{Aa}$ & 4,00 & $6,91 \mathrm{Aa}$ & 6,52 & $5,28 \mathrm{Aa}$ & 4,27 \\
\hline 110 & $3,86 \mathrm{Ab}$ & 5,07 & $5,99 \mathrm{Aa}$ & $\begin{array}{l}4,87 \\
\text { ESPIG }\end{array}$ & $5,10 \mathrm{Ba}$ & 4,92 & $8,31 \mathrm{Aa}$ & 4,05 \\
\hline 90 & $4,80 \mathrm{Aa}$ & 12,55 & $4,31 \mathrm{Aa}$ & 7,55 & $6,02 \mathrm{Aa}$ & 9,80 & $4,2 i \mathrm{Aa}$ & 4,72 \\
\hline 110 & $3,954 a$ & 9,92 & $5,20 \mathrm{Aa}$ & 9,57 & $6,29 \mathrm{Aa}$ & 9,85 & $6,33 \mathrm{Aa}$ & 5,25 \\
\hline
\end{tabular}

- Para cada cultivar, dentro de cada linha, as mëdias seguidas da mesma letra maiúscula e dentro de cada coluna para cada parte da planta, as médias de idade seguidas da mesma letra minúscula näo diferem significa ticamente entre $5 \mathrm{i}$, pelo teste de Tukey ao nivel de $5 \%$ de probabilida de. 
84.

idade. A cultivar IAC 24-Tucuruí não sofreu modificação no conteüdo do nutriente, nas duas disponibilidades de ägua, em todas as partes, com a idade somente as folhas em regime irrigado mostraram aumento.

Os maiores teores em ppm, nas duas cultivares, foram encontrados nas folhas e foltias bandeiras, no entanto o órgão mais acumulador de boro foram os colmos.

BATISTA (1974) em estudos de absorção de boro pelo feijoeiro, mostra que as plantas da época das águas absorvem maiores quantidades que na época das secas, mostrando a influência da disponibilidade de ägua sobre o acúmulo deste nutriente. 0 mesmo trabalho mostra aumento no acúmulo do nutriente nas folhas e caules até os 40 dias de idade e um posterior decréscimo até os 70 dias, final do ciclo, sendo que nas vagens hà um crescimento desde sua formą̧a até os 60 dias e depois estabiliza-se. FURLANI et alii (1977) estudando a . composição química do arroz, mostram que o teor médio de boro nas cultivares IR 665, IAC 435 e IAC 120 atinge 17 ppm, 10 ppm, 4 ppm.e 6 ppm, nas folhas, colmos, gräos descascados e cascas, respectivamente.

os resultados obtidos pelo wiltimo autor são parcilamente concordantes aos obtidos com trigo na presente pesquisa. 
85.

4.3.9. COBRE

Na Tabela 15 estão apresentadas as médias em mg por planta e as quantidades, em ppm, de cobre nas partes da planta de trigo de duas cultivares, dos. 90 e 110 dias de idade, influenciadas pela disponibilidade de água. os órgãos das plantas da cultivar BH 1146 mostraram maior acúmulo em re gime irrigado, no entanto, as folhas na idade de 90 dias, foIhas bandeira, grãos e espigas aos 11.0 dias não apresentam di ferenças com a mudança de disponibilidade de ägua. No final do ciclo, as folhas, folhas bandeira, grãos e espigas da cultivar IAC 24-Tucuruí, mostraram maiór acúmulo no tratamentoir rigado e os colmos no tratamento em sequeiro, com go dias o maior acūmulo ocorreu sem irrigação em todas as partes, porēm a anālise estatística mostra que nas folhas, gräos e espigas, não hà diferença.

Com relação a idade, as duas cultivares cultivadas nas duas disponibilidades não mostram diferenças no acū mulo do nutriente em nenhuma das partes, com excessão das foIhas da cultivar IAC 24-Tucuruí em sequeiro que mostrou maior acúmulo no final do ciclo.

Os maiores teores de cobre no final do ciclo, nas duas cultivares foram encontrados nas folthas e grãos, sen do que a irrigação proporcionou maior conteúdo nas follhas do que nos gräos. 
Tabela 15. Teores médios de cobre contidos nas partes da planta de duas cultivares de trigo estudadas em duas disponibilidades de água.

\begin{tabular}{|c|c|c|c|c|c|c|c|c|}
\hline \multirow{5}{*}{$\begin{array}{l}\text { Idade } \\
\text { da } \\
\text { planta } \\
\text { (dias). }\end{array}$} & \multicolumn{8}{|c|}{ Cultivar } \\
\hline & \multicolumn{4}{|c|}{ BH 1146} & \multicolumn{4}{|c|}{ IAC 24-Tucurui } \\
\hline & & & Dispon & bilidac & de de ägua & & & \\
\hline & \multicolumn{2}{|c|}{ Sequeiro } & \multicolumn{2}{|c|}{ Irrigado } & \multicolumn{2}{|c|}{ Sequeiro } & \multicolumn{2}{|c|}{ Irrigado } \\
\hline & $\mu \mathrm{g} / \mathrm{pl}$ & ppm & $\mu g / p l$ & $\begin{array}{l}\text { Ppm } \\
\text { COLMO }\end{array}$ & $\mu g / p l$ & $\mathrm{ppm}$ & $\mu \mathrm{g} / \mathrm{pl}$ & $\mathrm{ppm}$ \\
\hline 90 & $1,528 \mathrm{a}$ & 1,25 & $4,60 \mathrm{Aa}$ & 2,00 & $1,45 \mathrm{Ba}$ & 1,25 & $4,224 a$ & 2,00 \\
\hline 110 & $1,71 \mathrm{Ba}$ & 1,52 & $4,30 \mathrm{Aa}$ & 2,15 & $2,38 \mathrm{Aa}$ & 2,40 & $2,09 A \mathrm{~A}$ & $\begin{array}{c}1,05 \\
.\end{array}$ \\
\hline 90 & $1,35 \mathrm{Aa}$ & 3,75 & $2,39 A a$ & 3,75 & $0,76 \mathrm{Ab}$ & 2,00 & $2,64 \hat{A} a$ & 4,40 \\
\hline \multirow[t]{2}{*}{110} & $1,178 \mathrm{a}$ & $4,05^{\circ}$ & $4,02 \mathrm{Aa}$ & 7,15 & $2,43 \mathrm{Ba}$ & 6,05 & $4,744 a$ & 7,30 \\
\hline & & & & FOLHA & BANDEIRA & & & \\
\hline 90 & $0,18 \mathrm{Ba}$ & 2,25 & $0,72 \mathrm{Aa}$ & 4,00 & $0,17 \mathrm{Ba}$ & 1,50 & $1,44 A a$ & 5,30 \\
\hline \multirow[t]{2}{*}{110} & $0,29 A a$ & 3,25 & $0,4\} A a$ & 3,75 & $0,28 \mathrm{Aa}$ & 3,92 & $0,57 \mathrm{Aa}$ & 3,45 \\
\hline & & & . & GRÃO & & & . & \\
\hline 90 & 4,6482 & 5,75 & $8,75 A a$ & 7,26 & $5,45 A a$ & 5,00 & $7,35 \mathrm{Aa}$ & 6,35 \\
\hline \multirow[t]{2}{*}{110} & $3,65 \mathrm{Aa}$ & 4,85 & $5, ? 3 \mathrm{Aa}$ & 4,25 & $5,898 \mathrm{a}$ & 5,70 & $10,06 \Omega \mathrm{a}$ & 5,00 \\
\hline & & & & ESPIG & & & & \\
\hline 90 & $0,54 \mathrm{Ba}$ & 1,50 & $2,05 \mathrm{Aa}$ & 3,50 & $0,74 \mathrm{Aa}$ & 1,25 & $1,30 \mathrm{Aa}$ & 1,50 \\
\hline 110 & $0,41 \mathrm{Aa}$ & 1,05 & $0,54 \mathrm{Aa}$ & 1,00 & $1,35 \mathrm{Aa}$ & 2,05 & $1,85 \AA \mathrm{a}$ & 1,35 \\
\hline
\end{tabular}

- Para cada cultivar, dentro de cada linha, as médias seguidas da mesma letra malúscula e dentro de cada colune para cada parte da planta, as médias de idade seguidas da mesma letra minúscula näe diferem significa tivamente entresi, pelo teste de Tukey ao nivei de $5 \%$ de probabilide de. 
BRAR \& SEKHON (1978) estudando o efeito do zin co e cobre sobre o conteúdo de micronutrientes nos örgãos da planta de trigo, mostram que em 75 dias de idade o teor nocol mo foi de.4,8 ppm e no grão 7,7 ppm. $0 \mathrm{~s}$ valores encontrados ho mesmo órgão na presente pesquisa e os encontrados nos grãos são bastante próximos. ROBSON et alii (1984) analisando o con teúdo deste nutriente em follias novas de trigo, concluiu que a medida que aumenta a idade há redução do teor, apresentárido acs 33, 55,81 dias e na maturação, 4,4 ppm, 2,7 ppm, 2,2 ppm. e 0,7 ppm, respectivamente. 0 mesmo autor mostra que as folhas bandeira atingiram, no início do espigamento da planta 2,2ppm do nutriente. NAMBIAR (1976) estudando a resposta de oito cul tivares a diferente doses de cobre na solução nutritiva, veri ficou que a concentração deste nutriente nas folhas novas e colmos não apresentou diferença entre cultivares, ocorrendono entanto diferenças entre cultivares, quando analisadas as foThas velhas. 0 teor de cobre nas folhas bandeira das cultivares apresentou valores entre $1,37 \mathrm{ppm}$ e 2,52 ppm e no grão entre 0,25 ppm e 1,73 ppm. Tanto os teores nas folhas bande ra e dos grãos são superiores aos obtidos na presente pesquisa. Estas diferenças podem ser devaidas as diferentes condições de execução dos experimentos. Os resultados de GALRÃo E SOUSA (1985) são semelhantes aos deste trabaiho, onde foram determinados 5,4 ppme 5,5 ppm, nas folhas e gräos, respectivamente, no início do espigamento da cultivar de trigo BR10 . 
88.

\subsubsection{FERRO}

Os teores, em ppm, e. as quantidades em mg de ferro encontrados nas partes de duas cultivares de trigo cultivadas em duas disponibilidades de água estão apresentados na Tabela 16. Os colmos, folhas e grãos da cultivar BH il46, no final do ciclo mostraram maior acūmulo de fierro como tratamento irrigado, as espigas nas duas idades e colmos e foIhas aos 90 dias não apresentaram diferenças; as folhas bandeira acumularam maior quantidade com irrigação aos 90 dias e no final do ciclo não diferiram com as disponibilidades de água. As partes da cultivar IAC 24-Tucuruí, no final do ciclo, acumularam máior peso do nutriente através do tratamento irrigado, os colmos, folhas e.grãos na idade de 90 días não diferiram quanto ao acūmulo de ferro em função da variação de disponibilidade de água e as folthas bandeira atingiram maior peso com irrigação, ocorrendo o contrário com as espigas.

Na cultivar BH 1146, em sequeiro, a idade não influi sobre o acúmulo nos colmos, giãos e espigas, e nas folhas e folhas bandeira cresceu com o decorrer do tempo; com irrigaçäo da idade de 90 para 110 dias" nos colmos, folhas e espigas houve aumiento e näo influi sobre as folnas bandeira e grãos. A culitivar IAC 24-Tucuruí, mostrou tanto em condições de sequeiro como em irrigaçäo, crescimento rio acúmulo de fer ro com a idade, nos colmos e folnas; nas folnas bandeira e gräos näo howye diferença, nas espigas aumentou com idade no 
Tabela 16. Teores médios de ferro contidos nas partes da planta de duas cultivares de trigo estudadas em duas disponibilidades deágua.

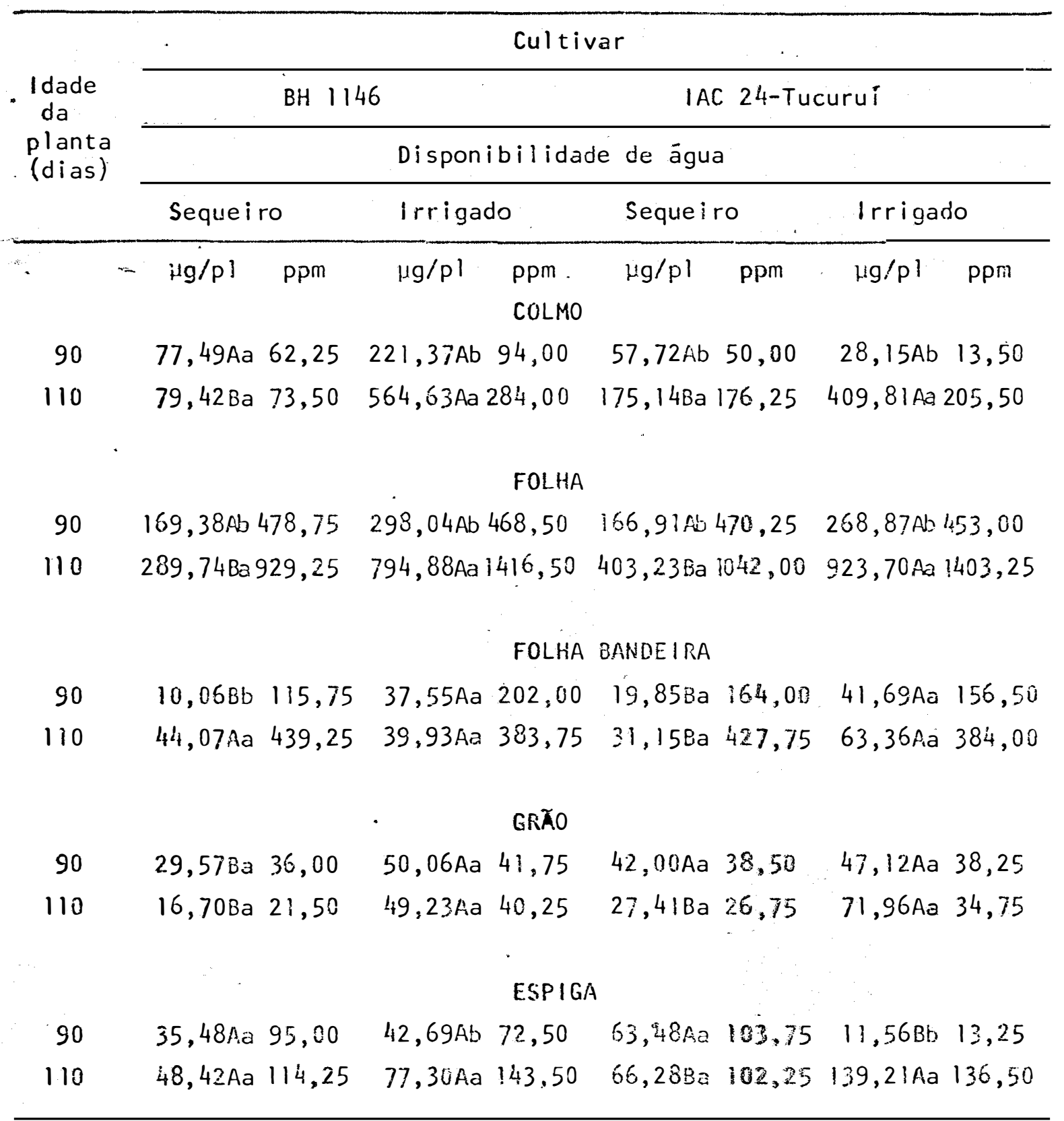

- Para cada cultivar, dentro de cada linha, as mëdias seguidas da mesma letra maluscula e dentro de cada coluna para cada parte da planta, as médias de idade seguidas da mesma letra mirúscula näo diferem significa tivamente entre si, pelo teste de Tukey a nivel de $5 \%$ de probobilia dáde. 
tratamento irrigado e permaneceu inalterado em sequeiro.

No final do ciclo, o maior acúmulo do nutriente para ambas as cultivares e disponibilidades de água foi en contrado nos colmos e folhas e o maior teor nas folhas, foIhas bandeira e colmos, com maior destaque para o tratamento irrigado. Em estudo semelhante com cinco cultivares e hibridos de milho, ANDRADE et alii (1977) relatam que na maturação final não houve diferença de acúmulo de ferro entre cu! tivares, sendo que neste mesmo estádio os brgãos mais acumula dores foram os pendões e colmos + folhas, independente da cu! tivar ou hibrido. GALRAo e SOUSA (1985) estudando absorfão de micronutrientes em um solo orgânico através da cultivar de trigo BR 10, constataram em média 123 ppme 57 ppm de ferro nas folhas e grãos das plantas desta. cultura.

\subsubsection{MANGANES}

Na Tabela 17 estão apresentadas as quantidades em mg e os teores, em ppm, de manganẽs nos örgãos de duas cultivares de trigo, em duas idades, cultivadas sob a influén cia de duas disponibilidades de ãgua. Os grãos e espigas da cultiva: 341146 näo mostraram diferenças no acúmuio do nutri ente com as disponibilidiades de água, ocorrendo de forma seme lhante com os colmos e folhas bandeira no final do ciclo e as folhas apresentaram maior acumulo através do tratamento irri- 
Tabela 17. Teores médios de manganês contidos nas partes da planta deduas cultivares de trigo estudadas em duas disponibilidades deāgua.

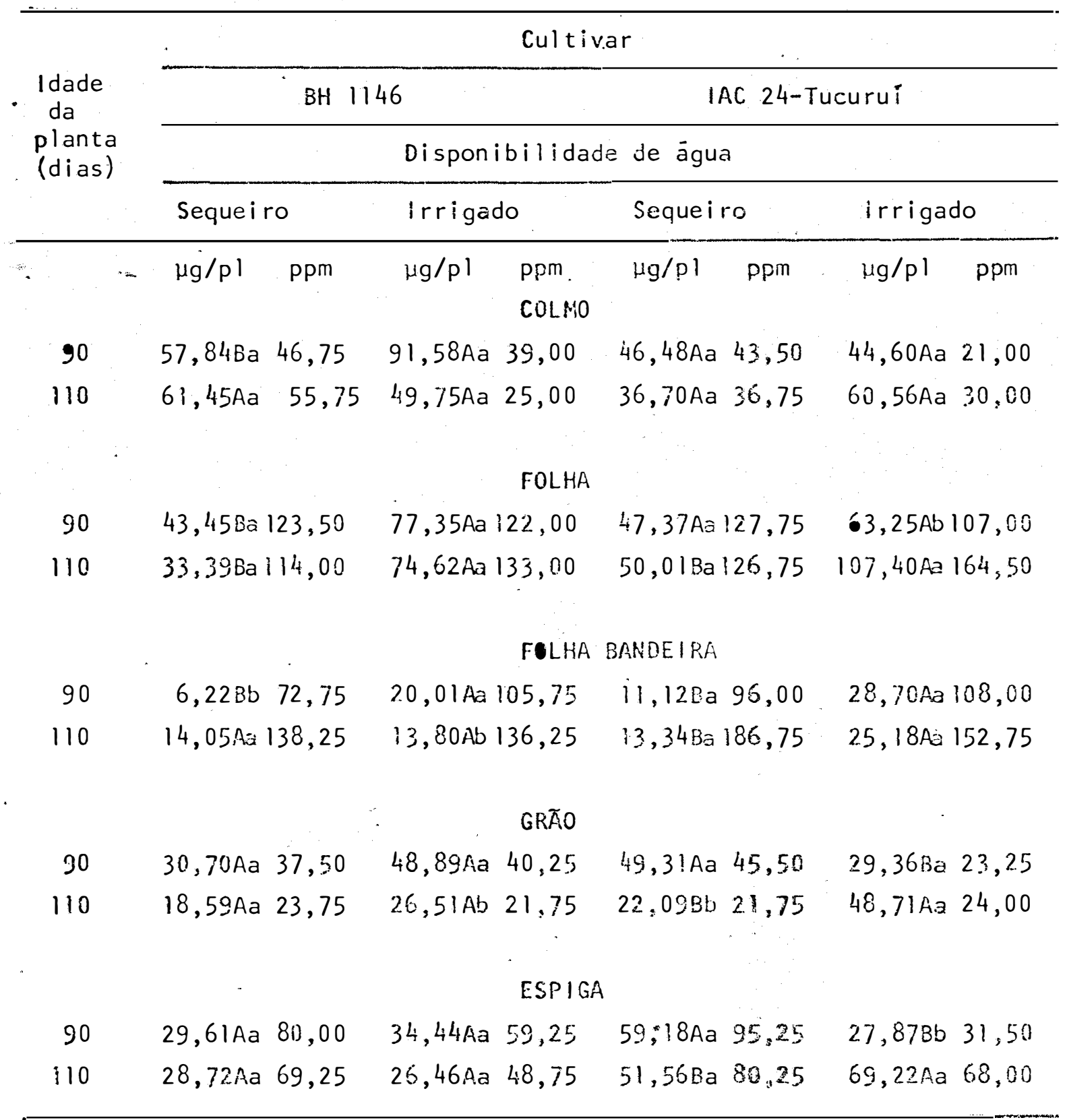

- Para cada cultivar, dentro de cada linta, as médias seguidas da mesma letra, maiúscula e dentro de cada coluna para cada parte da planta, as médias de idade seguidas da mesma letra minúscula ha diferem significa tivanente entre si, pelo teste de Tukey ao nivel de $5 \%$ de probabili= dade. 
gado. Na cultivar IAC 24-Tucuruí, no finai do ciclo, as foIhas, grãos e espigas acumularam maior peso do nutriente em regime irrigado; os colmos não mostraram diferenças com a variação da disponibilidade de àgua, sendo que as folhas bandei ra acumularam maior peso em irrigação, nas duas idades.

$$
\text { Em regime de sequeiro, na cultivar BH } 1146 \text {, }
$$

somente as folhas bandeira mostraram acümulo crescente de man ganês, as demais partes não sofreram alteração; com îrrigação as folhas bandeira e os grãos decresceu o acúmulo com o aumen to da idade e as demais partes não sorreram alteração. Na cul tivar IAC 24-Tucuruí, eni sequeiro o acūmulo não sofreu alteração com a idade nos colmos, folhas, folhas bandeira e espigas e os grãos acumularam maior peso aos 90 dias; em irriga ção o peso do nutriente permaneceu inalterado nos colmos, foIhas bandeira e grãos; nas folhas e espigas houve meior acúmu lo na maturação final.

o maior acúmulo de manganês, em ambas as cültivares e disponibilidades de água foi verificado nos colmos e folhas e o maior teor, nas folhas e folhas bandeira. GALRÃ E SOUSA (1985) analisando os teores de manganēs na parte aërea da cultivar de trigo $B R 10$ no iniçio do espigamento, encontraram em média, nas folhas e gräos, 106 e 59 ppm, respectivamente. Em estudo com diversas cultivares de trigo, em am biente controlado, NAMBIAR (1976) encontrou no grão teores en tre 16 e $45,3 \mathrm{ppm}$. Os teores encontrados pelos autores anteriores estão pröximos aos obtidos na presente pesquisa. Ho en 
tanto, BRAR \& SEKHON (1978) encontraram valores bem mais elevados do que os aqui relatados, 153 e 195 ppm, no colmo e foIhas, respectivamente.

Os diferentes teores relatados anteriormente, inclusive os desta pesquisa podem ser devido às adversidades nas condições de execução dos experimentos, principalmente a umidade do solo (FAGERIA, 1984).

\subsubsection{ZINCO}

As médias, em mg e as concentrações, em ppm, contidos nas partes das plantas de duas cultivares de trigo, aos 90 e 110 dias de idade, cultivados em duas disponibilida des de ägua estão apresentadas na Tabela 18. As folhas, grãos e ecpialda cultivar BH 1146 apresentaram maior acúmulo de zinco na presença do tratamento irrigado; os colmos e folhas bandeira näo apresentaram diferenças no final do ciclo e aos 90 dias acumularam mais peso com irrigação. Na ciltivar IAC 24-Tucurui, todas as partes mostraram maior acúmulo com irrigação, com excessão do grão que aos 90 dias de idade não mostrou diferença entre disponibilidades de ägua.

Na cultivar BH 1346 todas as partes das plantas cultivadas em sequeiro, as folhas, grãos e espigas com ir rigaçäo não mostraram alterz̧̧قo do conteüdo de zinco em peso com a idade. Com irigąão os colmos, folhas e folhas bándei ra desta última cultivar acumularam maior quantidade aos 90 
Tabela 18. Teores médios de zinco contidos nas partes da planta de duas cultivares de trigo estudadas emduas disponibilidades de agua.

\begin{tabular}{|c|c|c|c|c|c|c|c|c|}
\hline \multirow{5}{*}{$\begin{array}{l}\text { Idade } \\
\text { da } \\
\text { planta } \\
\text { (dias) }\end{array}$} & \multicolumn{8}{|c|}{ Cultivar } \\
\hline & \multicolumn{4}{|c|}{$\mathrm{BH} 1146$} & \multicolumn{4}{|c|}{ IAC 24-Tucuruí } \\
\hline & & & Dispor & nibilid & ade de àgu & & & \\
\hline & \multicolumn{2}{|c|}{ Seque iro } & \multicolumn{2}{|c|}{ Irrigado } & \multicolumn{2}{|c|}{ Seque iro } & \multicolumn{2}{|c|}{ Irrigado } \\
\hline & $\mu \mathrm{g} / \mathrm{pl}$ & $\mathrm{ppm}$ & $\mu \mathrm{g} / \mathrm{pl}$ & $\begin{array}{l}\text { Ppm } \\
\text { COLMO }\end{array}$ & $\mu \mathrm{g} / \mathrm{pl}$ & ppm & $\mu g / p l$ & $\mathrm{ppm}$ \\
\hline 90 & $5,10 \mathrm{Ba}$ & 4,25 & $17,47 \mathrm{Aa}$ & 7,50 & $4,04 B a$ & 3,50 & $10,78 \mathrm{Aa}$ & 5,25 \\
\hline 110 & $3.96 \mathrm{Aa}$ & 3,50 & $4,00 \mathrm{Ab}$ & $\begin{array}{l}2,00 \\
\text { FOLHA }\end{array}$ & $1,73 \mathrm{Bb}$ & 1,75 & $11,56 \mathrm{Aa}$ & $\begin{array}{r}5,75 \\
.\end{array}$ \\
\hline 90 & $1,49 \mathrm{Ba}$ & 4,25 & $5,16 \mathrm{Aa}$ & 13,25 & $1,11 \mathrm{Bb}$ & 6,00 & $5,73 \mathrm{Ab}$ & 9,75 \\
\hline 110 & $1,59 \mathrm{Ba}$ & 5,00 & $6,55 \mathrm{Aa}$ & $\begin{array}{c}11,75 \\
\text { FOLHA }\end{array}$ & $\begin{array}{r}2,24 B a \\
\text { BANDEIRA }\end{array}$ & 2,75 & $10,35 \mathrm{Aa}$ & 15,75 \\
\hline 90 & $0,22 \mathrm{Ba}$ & 2,50 & $1,84 \mathrm{Aa}$ & 9,75 & $0,71 \mathrm{Ba}$ & 5,75 & $2,87 \mathrm{Aa}$ & 11,00 \\
\hline 110 & $0,18 \mathrm{Aa}$ & 1,75 & $0,53 \mathrm{Ab}$ & $\begin{array}{l}5,25 \\
\text { GRXOO }\end{array}$ & $0,238 a$ & 3,25 & $1,41 \mathrm{Ab}$ & 8,50 \\
\hline 90 & $25,99 \mathrm{Ba}$ & 31,50 & $39,09 \mathrm{Aa}$ & 32,25 & $29,29 A a$ & 27,00 & $32,12 \mathrm{Ab}$ & 26,25 \\
\hline 110 & $.23,088 \mathrm{a}$ & 29,75 & $44,42 \mathrm{Aa}$ & 36,25 & $23,12 \mathrm{Ba}$ & 22,50 & $57,94 \mathrm{Aa}$ & 28,25 \\
\hline & & & & ESPIG & & & & \\
\hline 90 & $5,03 \mathrm{Ba}$ & 13,50 & $9,2.5 \mathrm{Aa}$ & 16,00 & $5,668 \mathrm{a}$ & 9,25 & $12,01 \mathrm{Aa}$ & 13,50 \\
\hline 110 & $3,73 \mathrm{Ba}$ & 9,00 & $8,164 a$ & 15,00 & $2,69 \mathrm{Bb}$ & 5,00 & $11,97 A a$ & 11,75 \\
\hline
\end{tabular}

- Para cada cultivar, dentro de cada linha, as médias seguidas da mesma letra maiúscula e dentro de cada coluna para cada parte da planta, as médias de idade seguidas da nesma letra minüsculas näo diferem signifi.cativamente entre si, pelo teste de Tukey ao nível de $5 \%$ de probabilidade. 
dias. Os colmos e espigas das plantas da cultivar IAC 24-Tucuruí em "sequeiro" apresentaram maior acúmulo com 90 dias de idade, as folhas com 110 dias e folhas bandeira e grãos não apresentaram diferenças com a idade; com irrigação as folhas e grãos acumularam maior peso na maturação final, folhas ban deira aos 90 dias e colmos e espigas não mostraram diferenças entre as idades.

$$
\text { o māximo acūmulo e concentração de zinco para }
$$
as duas cultivares em duas disponibilidades de àgua foi encontrado nos grãos.

GIORDANO \& MORTVEDT (1962) estudando a influên cia de doses de fösforo e zinco sobre o teor deste ültimo no tecido das plantas de arroz, constatou os maiores teores em tratamento com inundação do que sem inundação. No primeiro Eratamento o acúmulo médio de zinco foi de $0.75 \mathrm{mg} / \mathrm{pl}$, no segundo $0,20 \mathrm{mg} / \mathrm{pl}$. Com relação ao comportamento de diferentes genötipos na absorçãc de zinco, NAMBIAR (1gig) mostra que en tre dez cultivares de trigo; aveia e cevadacultivadas em ambiente controlado o teor deste nutriente nasi folhas ibandeira foi de 11 a 20,7 ppm. Analisando o teor she zinco das partes das plantas das cultivares de arroz IR 65 , IAC 435 e IAC 120 , FURLAN! et alii $(1977)$ obtiveram emédia nas fo-lhas, colmos, grãos descascados e cascas, $32,44,21$ e 27 ppm, respectivamente, mostrando diferença signifücativa entre as cultivares estudadas em todos os örgãos. Em estudos com tri*, em regime de sequeiro e irigado, BASSIRI E NAHAPETIAN 
(1977) não obtiveram efeito da disponibilidade de água sobre - teor de $Z n$ na planta, sendo que em ambas as disponibilidades de água, as plantas apresentaram em média de 32 a 57 ppm do nutriente. Nas partes da planta, BRAR \& SEKHON (1978) em determinação realizada aos 75 dias de idade obtiveram 20 e 23 ppm, respectivamente nos colmos e folhas.

\subsubsection{DISTRISUIÇÃO PERCENTUAL DE MATERIA SECA \\ E NUTRIENTES NOS ORGÃOS DA PLANTA}

Com base no acúmulo total de matéria seca e nu trientes na parte aérea da planta e nas partes da planta de trigo, foi estudada a distribuição proporcional para cada cul tivar e disponibilidades de água aos 90 e 110 dias de idade (Tabelas 19 e 20$)$. A comparação desta distribuição percen. tual permitiu analisar as alterações da composição dos órgãos da planta. Verificou-se que no tratámento com irrigaçäo para as duas cultivares a produção de matéria seca do colmo, órgäo que mastrou maior acúnulo, foi proporcionalmente maior em relação ao tratamento sem irrigạção, no entanio neste último, - gräo apresentou acúmulo proporcional maior para ambas as cultivares aos 90 dias de idade e aos 110 dias, a cultivar IAC 24-Tucuruí com irrigação mostrou maior produção proporcio na! de matëria seca no grão.

A distribuição percentual de nitrogênio, fösforo e cobre no grão das duas cultivares se apresentou mais 
Tabela 19. Distribuição percentual de matéria seca e nutrientes minerais nas partes das plantas de duas cultivares de trigo cultivadas em condições de sequeiro.

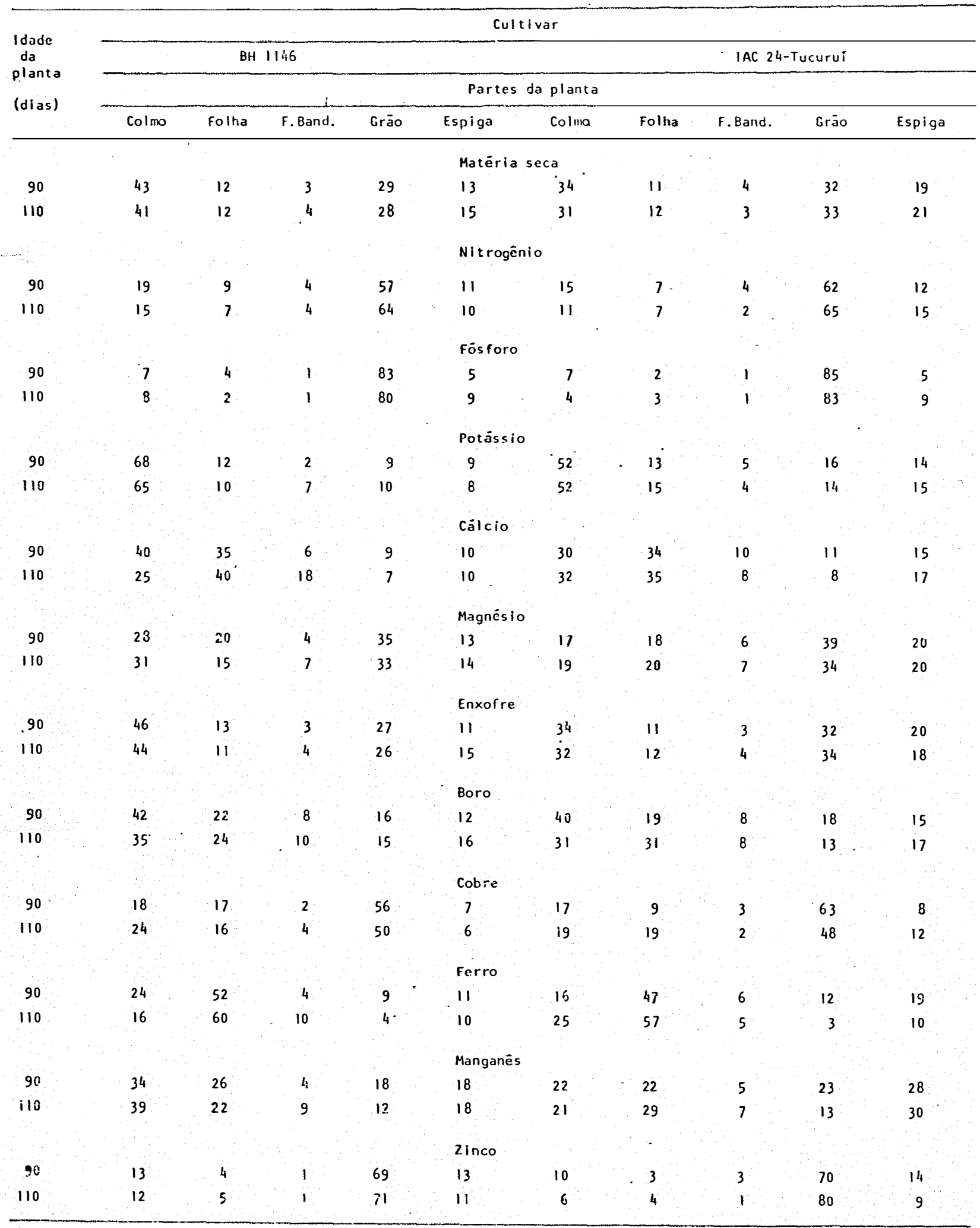


Tabela 20. Distribuição percentual de matéria seca e nutrientes minerais nas partes das plantas de trigo de duas cultivares cultivadas com irrigação.

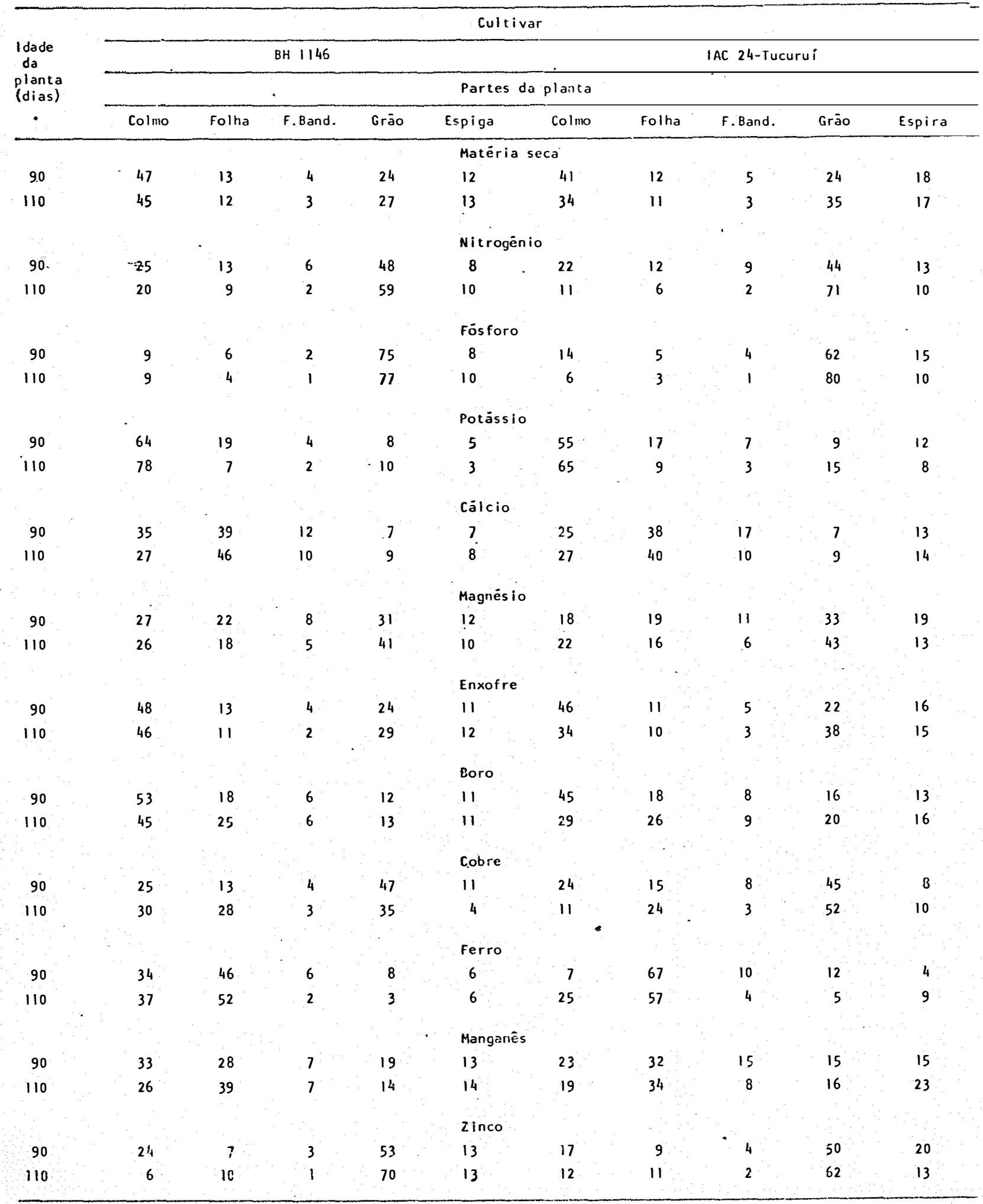


99.

elevada em regime de sequeiro, acontecendo o inverno com as partes vegetativas da planta. 0 potássio e ferro apresenta ram idêntica distribuição no grão para as duas cultivares nas duas disponibilidades de àgua, Com o magnēsio, enxofre e man ganês ocorreu maior distribuição para as cultivares no regime irrigado. Sendo que, para o cálcio, boro e zinco houve influência das cultivares sobre a sua distribuição no grão em cada dissponibilidade de água.

Com relação a idade da planta, em regime de sequeiro, nas duas cultivares o máximo acúmulo proporcional de nutrientes ocorreu aos 90 dias de idade, com exceção do n trogênio e potássio na cultivar BH 1146 e enxofre na cultivar IAC 24-Tucuruí que mostraram o máximo acúmulo proporcional aos 110 dias de idade. 0 zinco acumulou o máximo aos 110 dias, nas duas cultivares. Nos demais örgãos da planta na cultivar BH 1146 o acúmulo proporcional decresceu com a idade e na IAC 24-Tucuruí mostrou pequeno crescimento.

Em regime irrigado o acúmulo proporcional de nutrientes no grão cresceu com a idade nas duas cultivares, com excessäo do cobre e manganês na cultivar BH 1146 e ferro nas duas cultivares que decresceu. Nos demais örgãos houve decrēscimo do acúmulo proporcional de nutrientes com a idade, sendo que o potássio e ferro nas duas cultivares e cälcio na cultivar IAC 24-Tucurui mostraramcrescimento com a idade.

KARLEN \& WHITNEY (1980) mostram que o acümulo de matéria seca ria planta de trigo ocorre até antes da matu- 
ração fisiológica, havendo decréscimo posterior em função da dessecação, sendo que as espigas neste mesmo estádio apresentam 46\% da matéria seca total. Com relação ao nitrogênio,fósforo e potássio, WALDREN \& FLOWERDAY (1979) mostram que o mä ximo acúmulo nos órgãos vegetativos ocorreu até antes da floração e no grão até o estádio de grão mole, descrescendo a partir daí.

PETERSON (1965) menciona que os micronutrientes se encontram em maior quantidade nos grãos do que na palha do trigo. No entanto a presente pesquisa mostrou que somente o cobre e zinco atinge maior teor nos grãos, independente dadis ponibilidade de àgua e cultivar.

\subsection{Produgĩo de grãos}

As produções de grãos, peso de mil sementes e peso do hectolitro, obtidos nas duas cultivares em duas disponibilidades de āgua estão apresentadas na Tabela 21 . Foi verificada diferença na produção de grãos entre as disponibilidades de ägua sequeiro e irrigado para as duas cultivares e para peso de mil sementes, somente na cultivar BH 1146. O peso do hectolitro não apresentou diferenças nas duas cultivares quando consideradas as duas disponibilidades de água. Em regine de sequeiro, a produção de gräos, peso de mil sementes e peso do hectolitro na BH 1146 não foram afetados, sendo 


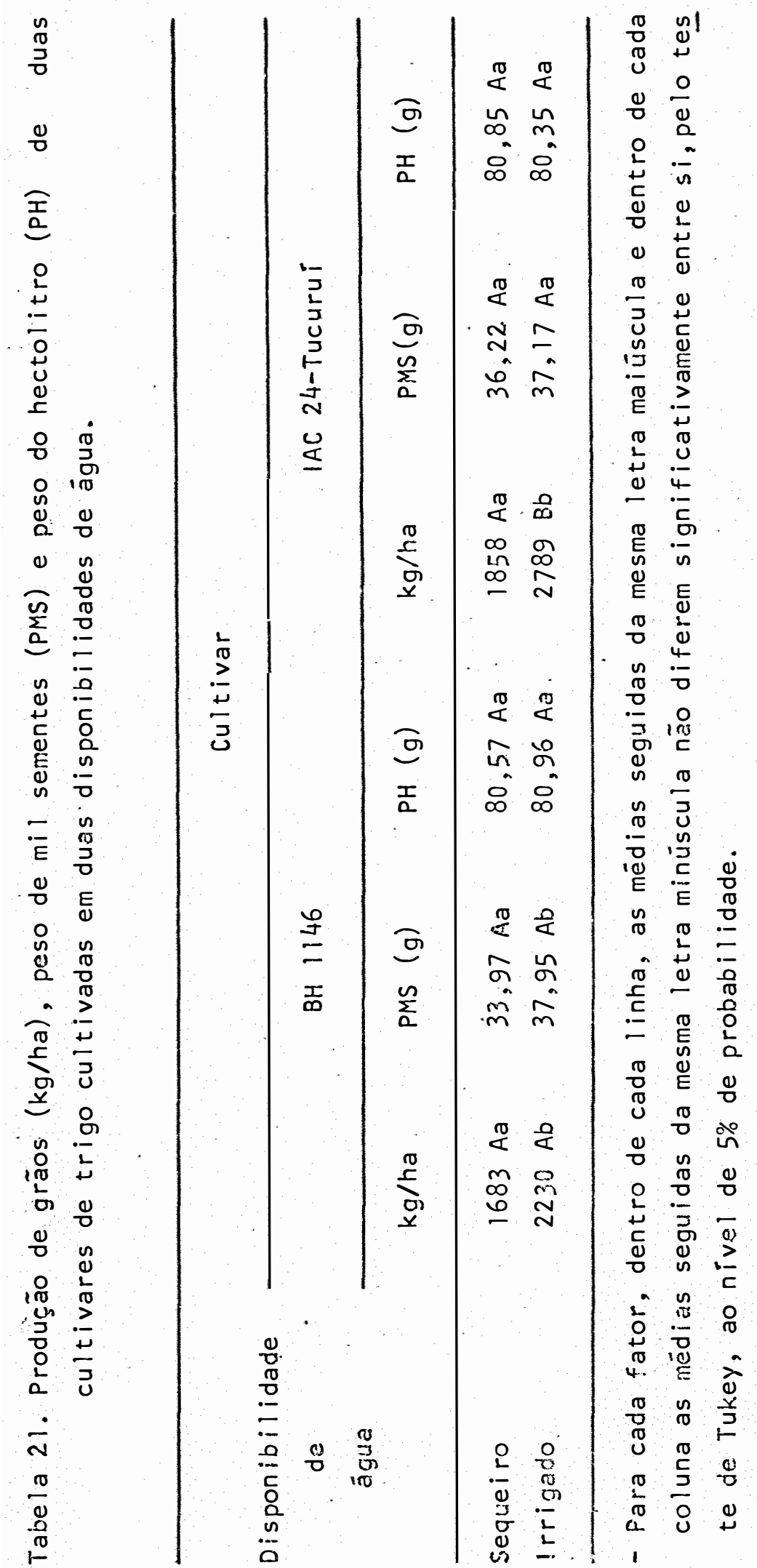


que, sob irrigação a cuìtivar IAC 24-Tucuruí apresentou maior produção e não foram modificados o peso de mil sementes e peso do hectolitro.

Apesar das duas cultivares não diferirem em pro đução de grãos em regime de sequeiro; ambas mostraram boa capacidade produtiva, pois as produções alcançadas são superiores as médias nacionais. SOUSA et alii (i984) e SOUSA et ali (1986) mostram o bom comportamento das cultivares testadas nesta pesquisa em cultivos sucessivos em condif̧ōes de se queiro en solos de alta fertilidade natural, do sul do Estado de Mato Grosso do Sul. De maneira semelhante CALHEIROS et alii (1986) em experimentos sucessivos com o uso de irrigaça por aspersão tem obtido altos rendimentos com a cultivar lAC 24-Tucuruí.

Em regiöes de acentuada deficiência hídricà na ëpoca de cultivo de trigo o uso da irrigação torna-se impres cindivel para obter-se bons rendimentos. SINGH et alii (1979) atrảvás do uso de quatro níveis de irrigação concluiram qua a medida qua diminuia o espaço de tempoentre turnos de rega, aumentava o rendimento de palha e grãos e SHARMA es alii (1981) em trabalho semelhante mostraram que com o aumento dos intervalos de rega houve reduçä́o no nümero de perfilhos/planta, número de gräos/espiga e peso de mil sementes. Com oa mesmos objetivos, SHIMSHI \& KAFKAFl (1978) estudaram o compor tamento dos componentes da produça de gräos, aplicando irrigaçoes em diferentes estádios da planta, sendo que o ereito 
mais positivo foi alcançado apos a germinação mais tratamento nã emissão da espiga, sendo que o tratamento sem irrigação, somente com àgua da chuva, produziu $64 \%$ em relação ao melhor tratamento irrigado.

\subsection{CONSUMO E EXPORTAEÃO DE NUTRIENTES}

o acūmulo total e exportação de nutrientes por área pelo grão, na maturação, com base na população final de plantas e acúmulo de cada nutriente está exposto na Tabeía 22. Tanto a cultivar BH 1146 como a IAC 24-Tucurui, apresentaram maior consumo de nutrientes no regime com irrigaçăo. Em sequeiro a cultivar BH 1146 consumiu maior quantidade de fósforo, potässio, magnésio, enxofre, manganès e zinco em relação a IAC 24-Tucuruí na mesma disponibilidade de água. já, com irrigą̧̃o a cultivar IAC 24-Tucuruí apresentou maior consumo de nitrogênio, fósforo, potássio, cälcio, magnésio, enxofre, cobre, manganês e zinco, sendo que somente o consumo

de boro e ferro foram menores nesta cultivar, quando compara dos a cultivar BH 1146.

Com relậão à exportação de nutrientes as duas cultivares exportaram em maior quantidade todos os nutrientes, quando receberam irrigação.

A exportação am sequeiro de nitrogênio, fös roro, potäsio, cálcio, boro, cobre, ferre e manganés foi 


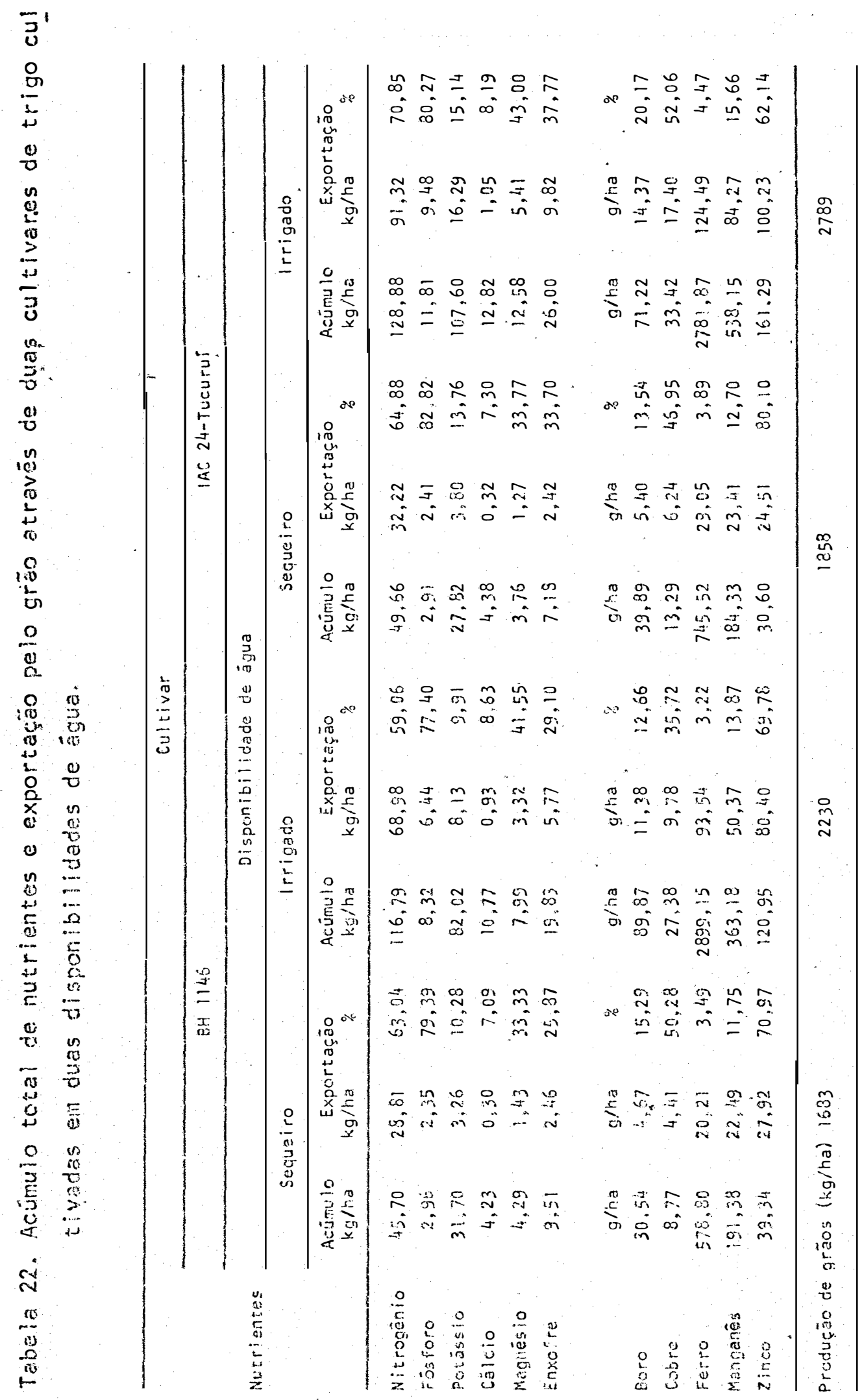


maior através da cultivar IAC 24-Tucuruí, sendo que magnésio, enxofre e zinco foram mais exportados através da cultivar BH1 146. No tratamento com irrigação, todos os nutrientes estudados, foram mais exportados pela cultivar IAC 24-Tucurui.

Em regime de sequeiro o consumo quartitiativo de macronutrientes obedece a seguinte ordem decrescente: $N>K>$ $\mathrm{S}>\mathrm{Mg}>\mathrm{Ca}>\mathrm{P}$, para a cultivar BH 1 i 46 , sendo que na $\mid \mathrm{AC} 24-$ Tucuruí, há maior consumo de cálcio em relação ao magnésio, os demais permanecem na mesma posição: Como uso da irriga ̧̧̃ã o consumo quantitativo apresenta sensiveis modif icações, co mo pode ser visto a seguir: $N>K>S>C a>P>M g$, para as duas cultivares, havendo tendência de na IAC 24-Tucutuí, o consumo de fósforo igualar-se ao de magnësio.

A exportação percentual de macronutrientes em relação ao consumo total é idêntico para as duas cultivaros, independente da disponitilidade de água, obedecendo a seguinte ordem: $\mathrm{P}>\mathrm{N}>\mathrm{Mg}>\mathrm{S}>\mathrm{K}>\mathrm{Ca}$.

o consumo quantitativo de micronutrientes nas duas cultivares, independente da disponibillidade de água epre senta-se na seguinte ordem decrescence: $\mathrm{Fe}>\mathrm{Mr}>\mathrm{Zn}>\mathrm{B}>\mathrm{CH}$, com excessão do boro que é mais consunido que zinco, riacul. tivar IAC 24-Tucurul sem o uso de irrigacão. A exportacãoper centual, atraves das duas cultivares nas afiponibilidades de água estudadas, obedece a seguinte ordem derrescente: zn > $\mathrm{Cu}>\mathrm{B}>\mathrm{Mn}>\mathrm{Fe}$, sendo que a sultivar bH ML6 sem irrigaçäo nostra maior exportaçẫo de mangariés cio que farro. 
o consumo e exportação de nutrientes ë variävel em função de alguns fatores, como cultivar, disponibilidade de āgua e mesmo as características do solo. GARGANTINI E BLANCO (1973) trabalhando em condições de ambiente controla do mostram que o consumo de macronutrientes obedece a seguinte ordem decrescente: $N \geq K>C a>M g>S>P$, sendo que a exportação percentual relativa ao consumo total se apresenta assim: $N>P>C a>M g>S>K$. Contata-se cóm a comparação das duas pesquisas, que independente das condifzés de execuçăo dos experimentos o nitrogênio e o potássio são cs macronutrientes mais consumidos e o fósforo e nitrogánio, os mais exportados em relação ao consunido. MCHEAL et al ii

mostran que apesar do acúmulo de nitrogênio, em cultivos com irrigação ser superior a cultivar sem irrigação, a exportação relativa deste nutriente nas ültimas é maior.

\subsection{EFICIÉNCIA NA UTILIZAGÃO DE NUTRIENTES}

Para estudo da eficiência de utilização de nutrientes minerais pelas cultivares de trigo nas duas disponibi lidades de ägua estudadas, foi estabelecido o quocients obtido entre produçäo de grãos e consumo de nutriente na matu. rą̧ăo final (Tabela 23). En regime de sequeiro a cultivar IAt 24-Tucuruí mostrou maior eficiencia na utilização de nitrogênio, fósforo, potássio, cälcio, magnếsio, enxofre, man- 


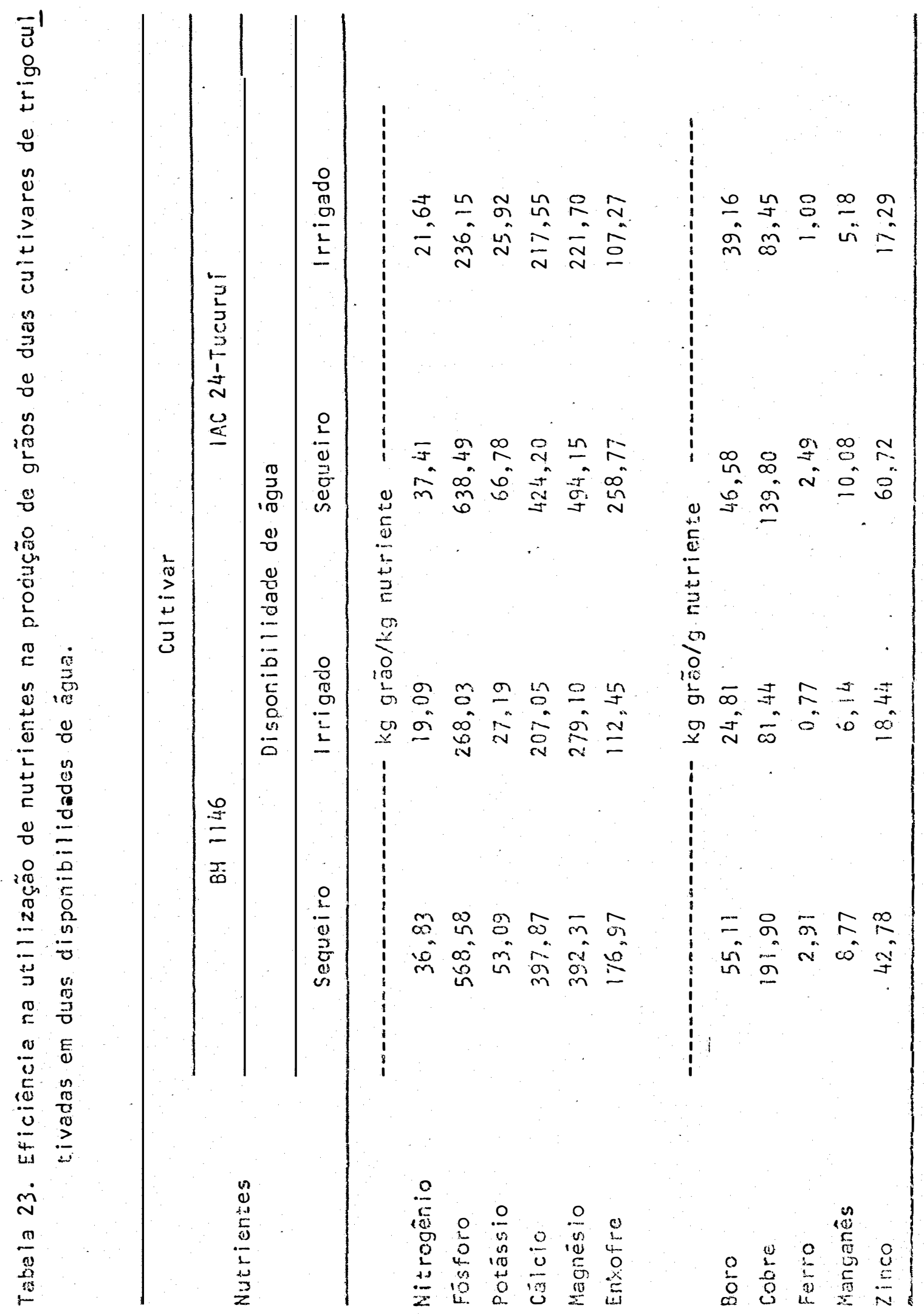


108.

ganês e zinco e a cultivar BH 1146 na utilização de boro, cobre eferro. No tratamento com irrigação a cultivar BH 1146 utilizou mais eficientemente o fösforo, potässio, magnésio, enxofre, manganês e zinco e a cultivar lAC 24 mucuruí o nitro gênio, cálcio, boro, cobre e ferro. Com relação às cultivares, ambas foram mais eficientes na utilizacáo de todos os nu trientes, quando cultivadas em regime de segueiro. Esta efi-

ciéncia das duas cultivares em sequeiro pade ser explicado por sua adaptabilidade as condiçoes de defiaiencia hídicica, as quais tem alcançado altos rendimentos, cunforme mostram sou SA Et ali $(1934)$ e SOUSA et alii (1986). Kesultados semethantes foram obtidos por GIUDICE et ali (1983) que trabaIhando com a cultivar de arroz IAC 1246, cogboa capacidade de resposta a deficiencia hidrica, constataram maior eficienncia na utilizaçäo de rutrientes em condições de sequeiro do que nos tratamentos com suprimento de agua fintermitente e inun daçäo permanente.

\subsection{CONGIDERACOES geraIS}

A produçäo de mátéria seca par planta e por uni dade de área, assim como a produçäo de grãos nas duas cultivares sofreram reduça con a diminulgăo da disponibilidade de ägua, comprousdo a alta capacidade do trigo em respon der a suprimentos adequados de água durante o seu asenvolvimerto. No en 
tanto o rendimento de grãos por unidade de ārea; em regime de sequeiro foi superior,quando comparado à produtividade média nacional, o que mostra também, a boa adaptabilidade desta cultura à deficiência hídrica, desde que, haja boa umidade para estabelecimento da cultura e o suprimento de àgua em. estádios críticos da planta.

o consumo e exportação de nutrientes através das culturas de arroz, mi tho e trigo, em diferentes disponibi lidades de ägua säo apresentados na Tabela 24 . Para este estudo comparativo foram considerados js valores médios de duas cultivares de arroz, cinco de milho e duas de trigo. 0 consumo de nutrientes pelo trigo com irrigaçäo é menor que o con sumo através do arroz com irrigação por submersão continua e o milho em sequeiro. Faz-se excessões ao $N$ que o trigo tem maior consumo em relação ao arroz e o S e fe em relação às duas espécies. Entre as três culturas o trigo mostra-se a me nos exigente e o milho a mais exigente.

Com relação a exportação de nutrientes, o trigo exporta apenas em maior quantidade o $N$.

A quantidade de nutrientes exportados pelas cul turas, alēm de ser dependente da exigência das mesmas é mais dependente da produçäo final das partes colhidas. Assim, como o milho apresentou maior producão por área, a sua exportá f̧ão de nutrientes tamö̈m mostrou maiores valores, o que signi fica que com o uso de melhores tëcnicas de cuitivo empregadas na cultura de trigo, como cultivares mais produtivas e de me 
110.

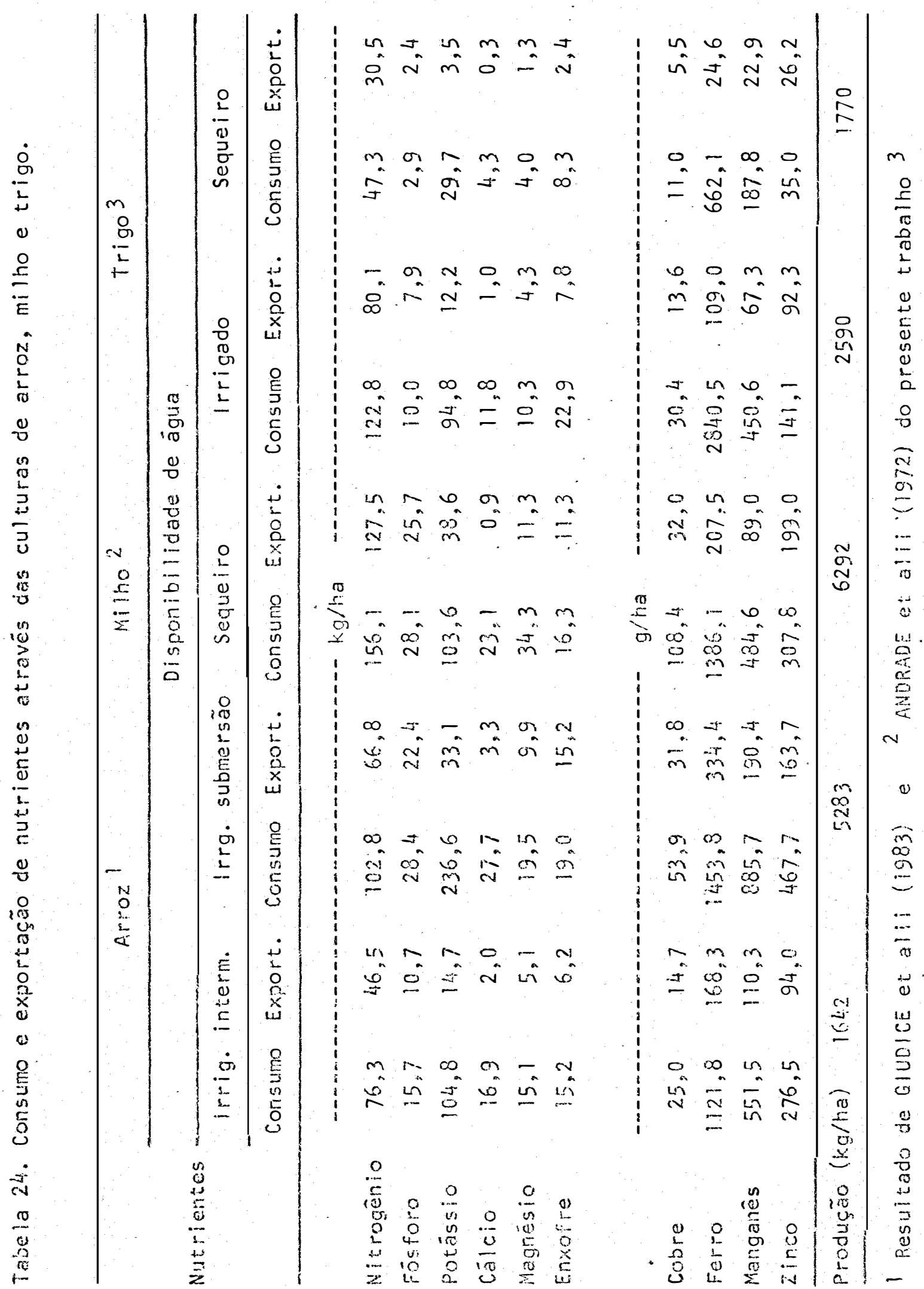


Ihor resposta a irrigação, houve maior exportação de nutrientes.

As necessidades de nutrientes pelas plantas são supridas pelos nutrientes da soluçã் do solo, quais são forne cidos pelas reservas do solo ou por fertilizantes aplicados a este. Para satisfazer estas necessidades são feitas aplica f̧ões ao solo, com base em recomendaçöes oriundas dos örgãos de pesquisa (Tabela 25). As quantidades recomendadas são baseadas nas necessidades da planta e estudos de adubaçäo com diferentes doses de fertilizantes. As recomendações de $p$ e K, comparadas ao consumo, são suficientes, no entanto em solos com baixa disponibilidade nestes nutrientes e em cultivos irrigados deven ser tomados cuidados especiais. A recomenda çäo de $N$ está abaixo do consumo, principalmente em cultivo irrigado, havendo necessidade de maior dosagem, principalmen te em solos com baixo teor de matéria orgânica e com o uso de cultivares de alto potencial de produção con irrigação. Cuidados semelhantes devem ser tomados com relação aos micronutrientes, principalmente com o $2 n$ e cu, pois estes são bastan te exportados pelos grãos, e mesmo que, como uso de melhom res adubações com $P, C a$ e Mg, diminuent suas disponibilidades para a planta no solo.

A maior eficiência na utilizaçăo de nutrientes, expressa em produção de gräos pelas plantas, em regime de se queiro, mostra que com o uso da irrigação são necessárias a utilizaçăo de outras tecnologias, principalmente cuitivares 
112.

com alto potencial produtivo, para garantir elevadas produções por unidade de àrea. Isto garante maier quociente da produção de grãos por consumo final de cada nutriente.

Tabela 25. Recomendações de adubaçäo nitrogenada, fosfatada e potássica para solos cem teores médios de $P$ e K nos Estados de Mato Grosso do Sul (MS) '́ Eăo Paulo $(S P)^{2}$ ?

Nutrientes a aplicar - $\mathrm{kg} / \mathrm{ha}$

Estado

Ná semeadura

Em cobertura

$\begin{array}{cccc} & \text { Na semeadura } & & \text { Em cobertura } \\ & P & K & N \\ 5-12 & 20-26 & 25,0 & 0-353 \\ 20 & 26 & 25,0 & 20-404\end{array}$

Reconiendaçós da EMBrapa $(1985)^{\prime}$ e CAMARgo, C.E.0. $(1985)^{2}$. 3 Em função do teor de matéría orgânica no solo.

4 Trigo em sequeiro não aplicar e com irrigarão aplicar $40 \mathrm{~kg}$ tha de $10,30-40$ dias após a emergencia e para cultivares de ciclo médio a tardio dividir a dose em duas partes, apiican do a segunda 50-60 dias apös a emergejcia. 
113.

5. CONCLUSOES

\subsection{CRESCIMENTO DA PLANTA}

a) O. tratamento com irrigaçäo proporcionol os maiores pesos de matéria seca por planta e matéria seca por àrea, nas duas cultivares e em todas as épocas analisadas.

b) O nümero de plantas por ärea considerando as cuitivares, apresentou variaçoes duranté o clelo, no entanto na thaturação, ambas as cultivares apresentaram maioi nünero coin irrigaçao.

5.2. ABSORGẼO E ACUMULO DE NUTRIENTES

a) As concentrações mínimas de macronutrientes nas duas cultivares en duas disponibilidades de ägua ocorreram na maturaçäo of no estádio de grão lesiroso e as de microm 
114.

nutrientes entre os estádios de floração e grão leitoso, geralmente próximos ou após ocorrér o máximo acúmulo de matéria seca.

b) Em regime de sequeiro, a cultivar BH 1146, na maturação, acumulou em $3282 \mathrm{~kg}$ de matéria seca, $46 \mathrm{~kg}$ de $N, 3 \mathrm{~kg}$ de $P, 32 \mathrm{~kg}$ de $\mathrm{K}, 4 \mathrm{~kg}$ de $\mathrm{Ca} ; 4 \mathrm{~kg}$ de $M_{g}, 9 \mathrm{~kg}$ de $\mathrm{S}$, $30 \mathrm{~g}$ de B, $9 \mathrm{~g}$ de $\mathrm{Cu}, 579 \mathrm{~g}$ de Fe, $191 \mathrm{~g}$ de $\mathrm{Mn}$ e $39 \mathrm{~g}$ de In por hectare, ao passo que a IAC 24-Tucurui acumulou em 3303 $\mathrm{kg}$ de matéria seca, $50 \mathrm{~kg}$ de $N, 3 \mathrm{~kg}$ de $P, 28 \mathrm{~kg}$ de $\mathrm{K}, 4 \mathrm{~kg}$ de $\mathrm{Ca}, 4 \mathrm{~kg}$ de $\mathrm{Mg}, 7 \mathrm{~kg}$ de $\mathrm{S}, 40 \mathrm{~g}$ de $B, 13 \mathrm{~g}$ de $\mathrm{Cu}, 745 \mathrm{~g}$ de Fe, $184 \mathrm{~g}$ de $4 n$ e $30 \mathrm{~g}$ de $2 \mathrm{n}$ por hectare.

c) Com irrigação, a cultivar BH 1146 , na maturação acumliou em $9136 \mathrm{~kg}$ de matéria seca, $117 \mathrm{~kg} d$ e $\mathrm{N}$, $8 \mathrm{~kg}$ de $P, 82 \mathrm{~kg}$ de $\mathrm{K}, 11 \mathrm{~kg}$ de $\mathrm{C} a, 8 \mathrm{~kg}$ de $\mathrm{Hg}, 20 \mathrm{~kg}$ de $\mathrm{S}, 90 \mathrm{~g}$ de $B, 27 \mathrm{~g}$ de $\mathrm{Cu}, 2899 \mathrm{~g}$ de $\mathrm{Fe}, 363 \mathrm{~g}$ de $M n$ e $121 \mathrm{~g}$ de $2 \mathrm{n}$ por hectare. A cultivar IAC 24-Tucuruí, acumulou em $10178 \mathrm{~kg}$ de materia seca, $123 \mathrm{~kg}$ de N, $12 \mathrm{~kg}$ de $\mathrm{P}, 107 \mathrm{~kg}$ de $\mathrm{K}, 13 \mathrm{~kg}$ de $\mathrm{Ca}, 12 \mathrm{~kg} d e \mathrm{Mg}, 26 \mathrm{~kg}$ de $5,71 \mathrm{~g}$ de $B, 33 \mathrm{~g}$ de $\mathrm{Cu}, 2872$, de Fe, 538 g de $k n$ e 161 g de $z n$ por hectare.

d) Was partes da planta das duas cultivares, in dependente da disponibilidade de ägua, o maior acúmulo propor cional de materia seca, $K$, S e B ocorreu nos colmos:de $\mathrm{Ca}$, $\mathrm{Fe}$ c Mn nas folhas $e$ de $M, P, M g, C u$ e $Z$ n nos grãos. 
115.

\subsection{Produgão de grãos e exportagão de nutrientes}

a) A produção de grãos foi diminuída nas duas cultivares com a restrição de ägua. A cultivar BH 1146 em se queiro produziu $1683 \mathrm{~kg} / \mathrm{ha}(75 \%)$ e com irrigação $2230 \mathrm{~kg} / \mathrm{ha}$ (100\%). A cultivar IAC 24-Tucuruí em sequeiro produziu 1858 $\mathrm{kg} / \mathrm{ha}(66 \%)$ e com irrigação $2789 \mathrm{~kg} / \mathrm{ha}(100 \%)$

* b) 0 tratamento em sequeiro reduziu o peso de mil sementes na cultivar BH 1146 e não afetou o peso do hecto. litro. Na cultivar IAC 24-Tucuruí não afetou os pesos cie mil sementes e do hectolitro.

c) A exportação percentual de nutrientes através dos grä́os segue a ordem:

$$
\mathrm{P}>\mathrm{N}>\mathrm{Hg}>\mathrm{S}>\mathrm{K}>\mathrm{Ca}>\mathrm{Zn}>\mathrm{Cu}>\mathrm{B}>\mathrm{Mn}>\mathrm{Fe}
$$

d) As duas cultivares apresentaram maior ef ciência na utilização de todos os nutrientes, àtravés do tra tamento em sequeiro. Com este tratamento a cultivar 34 11:6 mostrou malor eficiência na utilizagäo de $N, P, K, C a$, Mg, $S$,

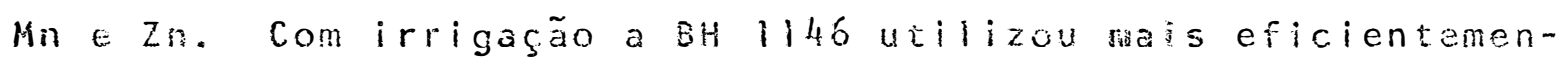
te o P, K, Mg, S, $\mathrm{H}_{\mathrm{n}} \mathrm{e} \mathrm{Zn}$ 
116.

\section{LITERATURA CITADA}

ALSTON, A.M., 1980. Response of wheat to deep placement of nitrogen and phosphorus fertilizers on a soil high in phos phorus in the surface layer. Australian Journal Agricultu re Research. Melbourne, 3i: $13-24$.

ANDRADE, A.l. de; H.P. HAAG; G.D. de OLIVEIRA e J.R. SARRUGE, 1977. Acumulação diferencial de nutrientes em cinco cult vares de milho. II - Acumulação de micronutrientes. In: ................ Acumulação diferençal de riutrientes em cin co cultivàres de milho. Piracicaba, ESALQ/USp, p.59-92.

BAKER, J.H. e B.B. TUCKER, 1973. Critical $\mathrm{M}, \mathrm{P}$ and $\mathrm{K}$ levels in winter wheat. Communications in soil science and plant Analysis. Madison, $4(5): 347-358$.

BANCO DO BRASIL S.A. Comercialização de Trigo Nacionai. Curi tiba. Area cultivada; produção e produtividade de trigo nos diferentes estados do Brasil. Curitiba, 1986. 1p. (Pu blicação avulisa). 
BASSIRI, A. e A. NAHAPETIAN, 1977. Differences in concentrations and interrelationships of phosphate, phosphorus, mag nesium, calcium, zinc and iron in wheat varieties grown un der dryland and irrigated conditions. Journal of Agricultural Chemistry. Shiraz, 25(5): $1118-1122$.

BATAGLIA, O.C.; C.E. de O. CAMARGO; O.F. de CAMARGO, V. NAGAl e V.J. RAMOS, 1985. Resposta a calagem de três cultivares de trigo com tolerância diferencial ao alumínio. Revista Brasileira de Ciëncia do Solo. Campinas, 9: 139-147.

BATISTA, C.M., 1974. Absorção e distribuigão de micronutrien tes ( $\mathrm{Cu}, \mathrm{Zn}, \mathrm{B}, \mathrm{Mn}$ ) no feijoeiro (Phaseolus vulgakis L.): efeitos da densidade e época de piantio. Viçosa. Universi ciede Federal de Viçosa (Dissertação de Mestrado).

BOATWRIGHT, G.O. e H.J. HAAS, 1961. Development and composi tion of spring wheat as infiuenced by nitrogen and phospho rus fertilization. Agronomy journal. Madison, 53: 33-36.

SRAR, M.S. e G.S. SEKHOAl, 1978. Effect of zinc and copper ap plication on the yield and micronutrient content of wheat (rriticum acstivum L.). Journal of Indian society soil Science. New Dehli, 25(1): $34-86$.

BRAsIL. Divisão de Pesquisa Pedoiögica. Departamento Nacional de Pesquisa Agropecuäria, 1971. Levantanento de Reconhecimento dos Solos do sul do Estado de Mato Grosso. Rio de saneiro. 839 p. (Bol. Tëc., 18).

BRASIL: Fundação Instituto Bräsileiro de Geografia E Estatís tica, 1985. Anuärio Estatisticodo Brasil-1984. Rio de Janeiro. $1104 p$. 
CALHEIROS, R. de 0.; R.T. AOKI; C.A.S. da SILVA, P.G. SOUSA E S.L. ROTOL1, 3986. Competição de cultivares de trigo irrigado. In: Reunião da Comissão Centro-Sul Brasileira de Pesquisa de Trigo, 2. Dourados, EMBRAPA. Resultados de Pesquisa com Trigo obtidos pela UEPAE de Dourados - EMBRAPA em 1985. P.86-96.

- CAMARGO, C.E.0., 1985. Recomendações de adubação e calagem para. trig.o. In: RAIJ, B. van, N.M. da SILVA, O.C. BATAGLIA e outros. Recomendações de adubação e calagem para o Estado de São Paulo. Campinas, Instituto Agronômico.p.26-27 (Ból. Téc., 100).

CAMPBELL, C.A.; H.R. DAVIDSON e F.G. WARDER, 1977. Effects of fertilizers $N$ and soil moisture on yield, yield components, protein content and $N$ accumulation in the aboveground parts of spring wheat. Canadian Journal of Soil Science. Otiawa, 57: $311-327$.

CARROL, M.D. e J.F. LONERAGAN, 1968. Response of plant species to concentrations of zinc in solution. 1 - qrowth and zinc content of plants. Australian Journal Agriculture Research. Melbourne, 19: 859-868.

CHAUDHRY, F.M. e J.F. LONERAGAN, 1970. Effects of nitrogen, copper, and zinc fertilizers on the copper and zinc nutritionof wheat plants. Australian Journal Aariculture Research. Melbourne, 21: $865-879$.

CoX, M.C.; O.R. CALVIN e D.W. RAINS, 1985. Cenetic variation for nitrogen assimilation and translocation in wheat. 1. Dry matter and nitrogen accumulation. Crop Science. Madison, 25: $430-435$.

DAY, A.D. e S. INTALAP, 1970. Some efiects of soil moisture on the growth of wheat (Thiticum aestivum L.). Agronomy Journal. Madison, 62: 27-29. 
EMPRESA BRASILEIRA DE PESQUISA AGROPECUARIA - Centro NaCionaI de Pesquisa de Trigo, Passo Fundo, 1983. Contribuição do CNPT/EMBRAPA ao treinamento sobre a cuitura do trigo. Dourados, v.1., p. 334-379.

EMPRESA BRASILEIRA DE PESQUISA AGROPECUARIA - Centro NaCional de Pesquisa de Trigo, Passo Fundo, 1984. Trigo - Resumos. informativos. Brasilia, EMBRAPA-DDT, v.1, p.257-293.

EMPRESA BRASILEIRA DE PESQUISA AGROPECUARIA - SERVi̧̧O NaCIOnal de Levantamento e Conservação de Solos, 1981. Coletâ.nea Bibliografica 1974-1980, Rio de Janeiro, 197 .

EMPRESA BRASIIEEIRA DE PESQUISA AGROFECUARIA - Unidade de Execução de pesquisa de Ámbito Estadual, Dourados, 1985. Irigo - Recomendacóes técnicas para Mato Grosso do Sul, safra 1985. Dourados, $45 \mathrm{p}$.

FAGERIA, N.K., 1984. Solos alagados - disponibiiidade de nutrientes e seu modelo de adubação da cultura de arroz irrigado. In: -............. Adubaçäo e Nutrição Mineral da Cultura de Arroz. EMBRApAiEd. Campus, Golanio/Rio de Jane ro. C.ap. 6, p.189-218.

FJELL, C.L.; G.M. PAULSEN; T.L. WALTER e J.R. LAWLESS, 1984. Relationship among nitrogen and phosphorus contents of ve-getative parts and agronomic traits of normal and high pro tein wheats. Journal of plant Nutrition. New York, 7(7): $1093-1102$.

FOOD AHD HGRICULTURE ORGANIZATION OF THE WWTEC NATIONS (FAO), 1984. Wheat. Production. Yearbook. Rome, 38: 110-111. 
FURLANI, P.R.; O.C. BATAGLIA e M.C. FURLANI, 1977. Composição química inorgânica de três cultivares de arroz. Bragantia. Campinas, 36 (8): 110-115.

GALLO, J.R.; R. HIROCE; O.C. BATAGLIA e M. ALCOVER, 1972. TeO res de alumínio, manganês, fósforo, potássio, cálcio e mag nésio em sessenta variedades de trigo e sua relação como "crestamento". Bragantia. Campinas, 31: XXXV-XLI.

GALRÃO, E.Z.; A.R. SUHET e D.M.G. SOUSA; 1978. Efeito de micronutrientes no rendimento e composição química do arroz (Oryza sativa L.) em solo de cerrado. Revista Brasileira de Ciência do Solo. Campinas, 2: 129-132.

GALRÃO, E.Z. e.D.M.G. de SOUSA, 1985. Resposta do trigo àapli cação de cobre em um solo orgãnico. Revista Brasileira de Ciêricia do Solo... Campinas, 9: 149.153.

GAMA, M.V., 1977a. Efeito do azoto e do potässio na composi ção mineral do irigo "impeto" e do tomate "roma". Agrono mia Lusitiana. Lisboa, 38(2): $111-121$.

GAMA, M.V., 1977b. Um caso provável de deficiência de enxofre em trigo cultivado em vasos. Agronomialusitana. Lisboa, $38(2): 123-126$.

GARGANTINI, H. e H.G. BLANCO, 1973. Absorção de nutrientes pelo trigo. Bragantia. Campinas, 32(i6): 285-307.

CASSER, U.K.R. E M.A.P. THOREURN, 1972. The growth, composition and rutrient uptake of spring wheat - Effects of fertilizer-N, irrigation and CCC on dry matter and $\mathbb{N}, P$, K, Ca, Mg and Na. Journal of Agricultural Science. Cambridge, 78: $393-404$. 
GIORDANO, P.M. e J.J. MORTVEDT, 1972. Rice response to zinc in flooded and nonflooded soil. Agronomy Journal. Madison, $64: 521-524$.

GIUDICE, R.M. del; H.P. HAAG; J.T.L. THIEBAUT E A.R. DECHEN,

- 1983. Absorção cumulativa de nutrientes minerais em duas. variedades de a: roz (Oryza sativa l.), cultivadas em trés. diferentes niveis de disponibilidade de áoua. Campinas, Fundação Cargill. $115 p$.

$\because$

GRAHAM, R.D.; W.J. DAVIES e J.S. ASCHER, 1985. The critical concertration of manganese in field-grown wheat. Austrailian. Journal Agriculture Research. Melbourne, 36: 145-155.

GREGORY, P.J.; D.V. CRAWFORD E M. MCGOWAN, 1979. Nutrient re-* lations of winter wheat: 1. Accumulation and distribuion of $\mathrm{Na}, \mathrm{K}, \mathrm{Ca}, \mathrm{Hg}, P, S$ and $N$. Journa! of Agriculture Science. Cambidge, 23: $485-494$.

GULATI, K.L.; M.C. OSWAL E K.K. NAGPAUL, 1980. Effect OF concentration of boron in the uptake and yield of tomato and wheat at different levels of irrigation. plant and Soil. Netherlands; 54: 479-484.

KALKKANN, R.E. E M.M. PILCZER, 1966. O solo e adubąäo do trí go em Santa Catarina. In: ......... Solo e adubacäo do trigo. Pelotas, Ministério da Agricultura, Instituto de Pesquisas e Experimentação Agronämica do sul. p.35-40. (Pu blicacäo avulsa).

KARLEN, D.L. E D.A. WHITNEY, 1980. Dry matter accumulation, mi neral concentrations, and nutrient distribution in winter wheat. Agromomy journa:. Madison, 22: 281-288. 
LUCAS, R.E. e B.D. KNEZEK, 1972. Climatic and soil conditions promoting micronutrient dificiencies in plants. In: MORTVEDT, J.J.; P.M. GIORDANO e W.L: LINDSAY, ed. Micronutrients. in Agriculture. Madison, Soil Science Society American, Cap. 12, p.265-283.

MALAVOLTA, E.; H.P. HAAG; F.A.F. MELLO e M.O.C. BRASIL SOBRINHO, 1974. Nutrição mineral e adubação de cereais diversos. In: -....... Nutrição Mineral e Adubação de Plantas Cultivadas. São Paulo, Pioneira, Ed., cap. 7, p.325-

$-419$.

MAZAHRI, A., 1976. Preparation and use of azometine-H for colorimetric determination of boron. Commications in Soil science ard Plant Analysis. New York, 7(3): 33i-334.

MCNEAL, F.H.; M.A. BERG e C.A. WATSON, 1966. Nitrogen and dry matter in five spring wheat varieties at successive sta ges of development. Agronomy Journal. Wadison, 58: 605608 .

MCNEAL, F.H.; G.0. BOATWRIGHT; M.A. BERG e C.A. WATSON, 1968 . Nitrogen in plani parts of seven.spring wheat varieties at successive stages of development. Crop Science. Madison, 8: $535-537$.

MOTA, F.S. da, 1982. Clima e zoneamento para a ti iticultura no Brasil. In: Fundação Cargill. Trigo no Brasil. Campinas, v. I., p.29-58.

MUZILLI, 0. e M.A. HOEPNER, 1981. Adubação do trigo no Estado do Paranā. In: IAPAR. Cuitura do trigo no Estado do. Parans. Londrina. p. 35-56. (Circ. Tëc. 22). 
NAMBIAR, E.K.S., 1976. Genetic differences in the copper nutrition of cereals. 11. Genotypic differences in response to copper in relation to copper, nitrogen and other mineral contents of plants. Australian Journal Agriculture Research. Melbourne, 27: 465-477.

ORPHANOS, P.1. e U.D. KRENTOS, 1980. Concentration of N, P and $K$ in leaves, straw and grain of wheat and barley as in fluenced by $N$ and $P$ fertilizers urider semi-arid conditions. Journal of Agricultural Science. Cambridge, 94: 551-556.

osorlo, E.A., 1982. Variedade e melhoramento. In: Fundação Cargill. Trigo no Brasil. Campinas, v.1., p.147-175.

PAGE, M,B.; J.L. SMALLEY e O. TALIBUDEEN, 1977. The growth and nutrient uptake of winter wheat. Plant and Soil. Netherlands, $49: 149-150$.

PETERSON, R.F., 1965. Wheat - Botany, cultivation, an utilization. New York, Leonard Hill Book ed. $417 \mathrm{p}$.

RASMUSSEN, P.E.; R.E. RAMIG; R.R. ALMARAS e C.M. SMTH, 1975. Nitrogen-sulfur relations in soft white winter wheat. 11. Initial and residual effects of sulfur applications on rutrient concentration, uptake, and N/S ratio. Agronomy Journal. Madison, $67(2): 224-228$.

REMY, T.H., 1938. Fertilization in its relationship to the course of nutrient absorption by plants. Soil science. New Jersey, $46(3): 187-209$.

RENNIE, D.A., 1956. Variations in percentage phosphorus and protein content of wheat, as induced by fertilizer treatment, soll type, and season. Canadian Journal of Agricultural science Ottawa, 35: $490-504$. 
ROBSON, A.D.; J.F. LONERAGAN; J.W. GARTRELL e K. SNOWBALL, 1984. Diagnosis of copper deficiency in wheat by plant analysis. Austrlian Journal of Agriculture Research. Melbourne, $\underline{35}$ (3): $347-358$.

SARRUGE, R.P. e H.P. HAAG, 1974. Anälises Químicas em Plantas. Piracicaba, ESALQ/USP. 56p. (Publicação avulsa).

SHARMA, R.P.; S. RAY E K.S. PARSHAR, 1981. Studies on agro- techniques for reduzing irrigation requirement with bet ter utilization of nutrients by irrigated wheat. Indian Journal Agronomy. Haryana, 26 $(4): 387-392$.

SHIMSHI, D. e U. KAFKAFI, 1978. The effect of supiemental ir rigation and nitrogen fertilization on wheat (Triticum aes tivum L.j. Irrigation Science. New York, 1:27-38.

SILVA, A.R. da, 1971. Trigo no sul de Mato Grosso. Rio de Janeiro, Ministērio da Agricultura - DNPEA. $24 \mathrm{p}$.

SILVA, A.R. da, 1976. A cultura do trigo irrigado nos cerrados do Brasil Central. Circular Técnica CPAC. Brasília (1): $70 p$.

SILVA, C.A.S. da; P.G. SOUSA; N.B. FARIA; M.G. RIBEIRO; P.R. A. ARAOJO; C. PEREIRA a E. VENTURINE, 1982. Competí̧̧̃o de cultivares de trigo irrigado. In: Reunião da Comissão Nor te Brasileira de Pesquisa de Trigo, 8. Belo Horizonte. RE sultados de pesquisa com Trigo obtidos na UEPAE de Dourados - EMBRAPA em 1981, p.43-53.

SINGH, A.P.; R. SAKAL; K.N. THAKUR e H. SINHA, 1980. Response of wheat to zinc and its critical level in old alluvium soils. Journal of Agricuitural Science. Cambridge, 95 : $175-179$. 
SINGH, N.T.; A.C. VIG; R. SINGH e M.R. CHAUDHARY, 1979. Influence of different levels of i.rrigation and nitrogen on yield and nutrient uptake by wheat. Agronomy Journal. Madison, 71: $401-404$.

SINGH, S.D. e R.K. AGGARWAL, 1976. Yield and nitrogen utilization by wheat in relation to moisture and fertility levels. Annals of Arid Zone. Jodgpu, is(1,2): 43-52.

SOUSA, P.G.; C. LAZZAROTTO; C.M. TAVELLA; R.T. AOKI; M.R. PERALTA e M. RUMIATTO, 1986. Ensaio Estadual de cultivares. In: Reuniăo da Comissão Centro-Sul Brasilleira de Pesquisa de Trigo, 2. Dourados, Resultados de Pesquisa com Trigocom Trigo obtidos pela UEPAE de Dourados - EMBRAPA em 1985. P. 22-29.

SOUSA, P.G.; D.R. SONEGO; C.M. TAVELLA; C. PITOL E C. LAZZAROT To, 1984. Ensaio estadual de cuitivares de trigo. In: Reu nião da Conissão Norte Brasileira de Pesquisa de Trigo, 10. Campinas, Resultados de Pesouisa com trigo obtidos peia UEPAE de Dourados - EMBPAPA em 1983, p. 12-19.

TOMASINI, R.G.A., 1982. Evolução histörica e aspectos econômicos. In: Fundação Cargill. Trigo no Erasil. Campinas, v.1., p.3-26.

WALDREN, R.P. E A.D. FLOWERDAY, 1979. Grawth stages and distribution of dry matter, $N, P$, and $K$ in winter wheat. Agro nomy Journal. Madison: 71: $391-397$. 